العـــــــد السـابع والثلاثون

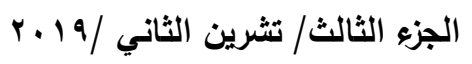

جامعة واسط

مجلـــــة كليـــــة التربيـــــة

\title{
دراسة في نسبة العين للخليل
}

أ. هند عامر صالح النباتي

كلية اللغة العربية- جامعة أم القرى/ مكة المكرمة عالع التئ

hand-a-n@ hotmail.com

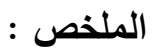

هدفت هذه الدراسـة إلى التثبت من صحة نسبة كتاب العين إلى الخليل أو بطلانهـا، من خـلد

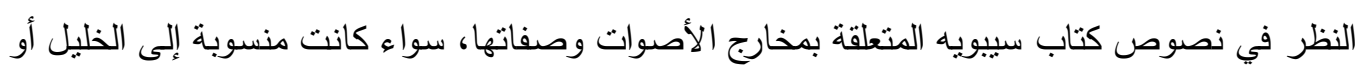

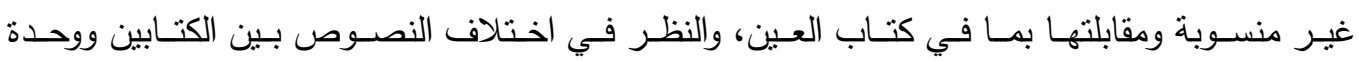

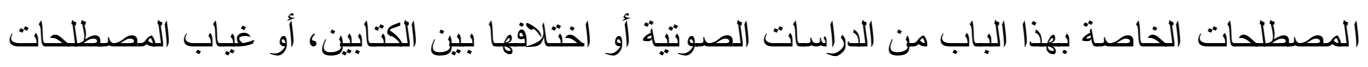

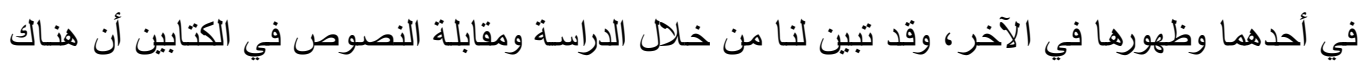

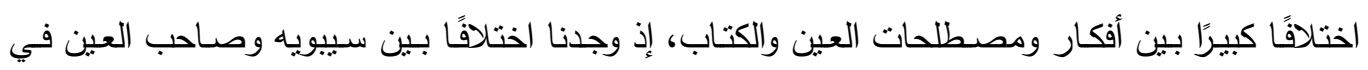

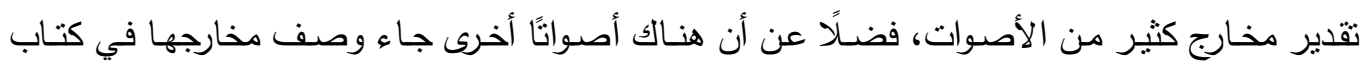

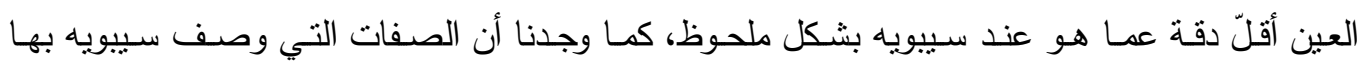

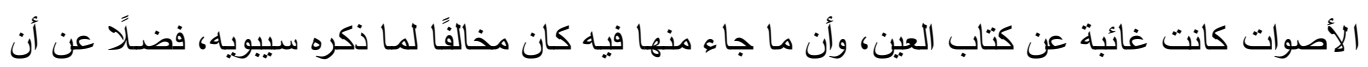

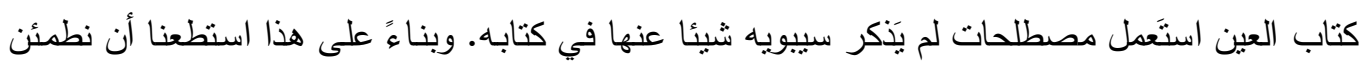

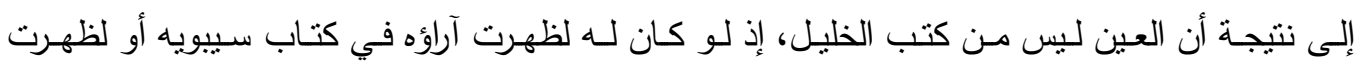

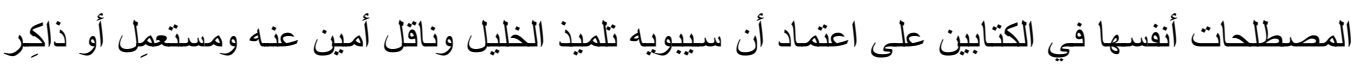
لمصطلحاته وآرائه في الأقل. 
العـــــــــد السابع والثُلاثون

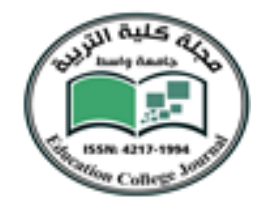

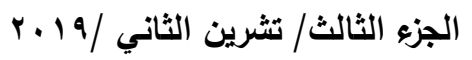

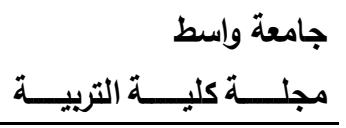

A study for Reviewing the Attribution of Al-Ain Book to AL-Khalil

Abstract:

This study aimed to authenticate whether ALAIN Book is attributed to ALKHALIL or not through considering the texts of Sibawayh book related to phonetics and articulation of sounds whether attributed to Al-Khalil or not comparing them to the texts of Al-Ain book as well as considering the discrepancy of the texts of the two books and the unity of terms related to phonetics or the absence of terms in either two books. Through studying and comparing the texts of the two books, it was revealed that there is great discrepancy between the ideas and terms of Al-Ain book and Sibawayh book. There is a difference in the two books regarding estimating the articulation sounds and that many articulation sounds in Al-Ain book were less accurate than articulation sounds in Sibawayh book. The study also revealed that the characteristics Sibawayh used to describe sounds were absent in Al-Ain Book and the sounds in Al-Ain were different from Sibawayh book and that Al-Ain book used terms Sibawayh did not use in his book Finally; the research concludes that Al-Ain book is not attributed to Al-Khalil. If this book had been for Al-Khalil, his opinions would have been appeared in Sibawayh book and the terms would have been mentioned in the two books noting that Sibawayh is the student of Al-Khalil and report the terms and opinions of Al-Khalil honestly .

نجد في مقدمة العين دراسـة صوتية مهمة لأصوات العربية تتاولها أكثر من باحث بالدراسة، إذ ثُاقش المقدمة في جانبها الصوتي ترتيب مخارج حروف العربية ووصف هذه المخارج، وصفات الأصـوات

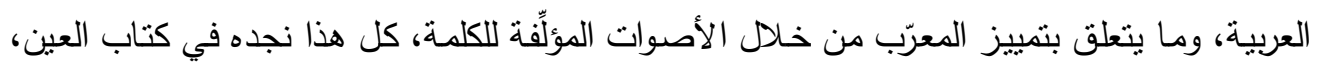
ولكن في المقابـل لا نجد في كتاب سييويه الذي امتلأ بـآراء الخليـل إشـارات إلى أفكارِ للخليل فيمـا

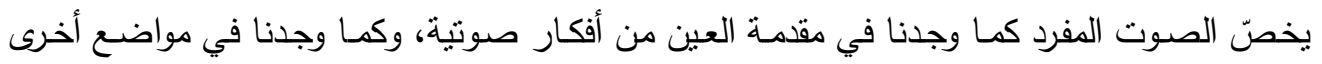
من العين مما يثير الاستغراب، فنلاحظ أن سييويه لم يذكر الخليل في دراسـة حروف العربية تمهيدًا لشرح مسائل الإدغام، كما أنتا لا نـاحظ شبهًا واضحًا بين مادة العين والكتاب في موضـع المخـارج 
والصفات يدل على تأثر أو تأثير ولا مناقثة بينهـا حول هذه الاختلافات، ونرجح أن سييويه كتب

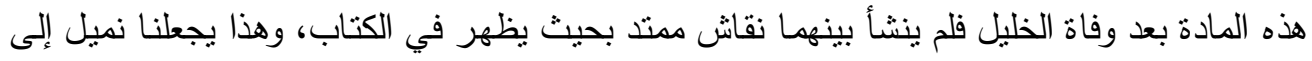

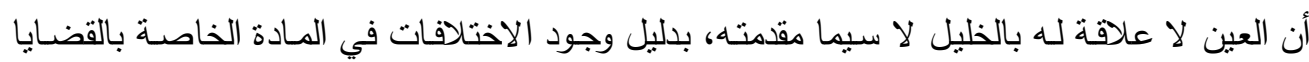

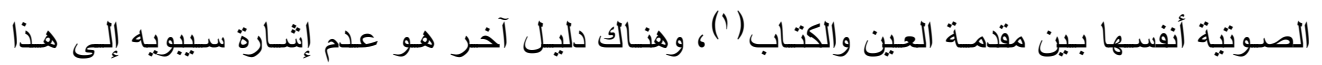

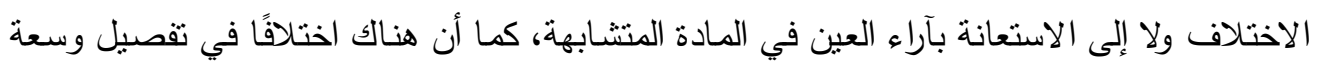

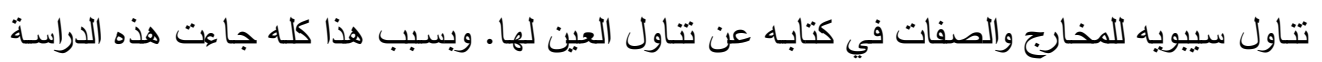

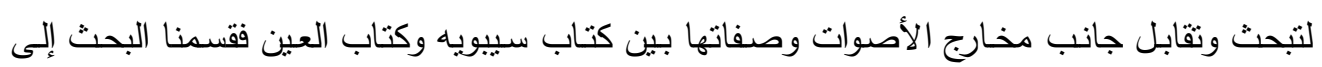

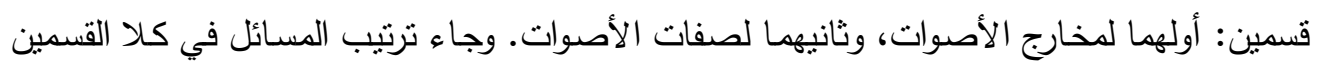

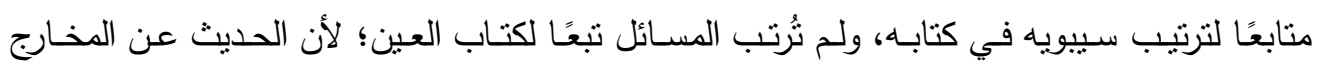

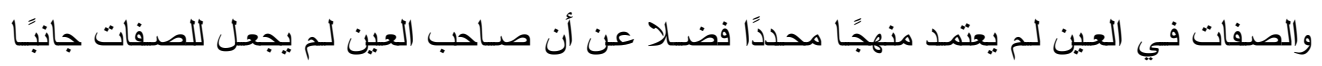

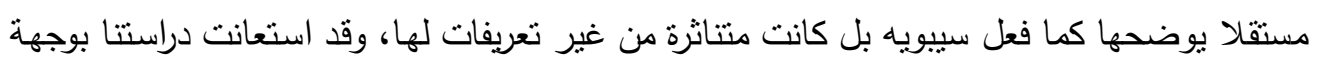

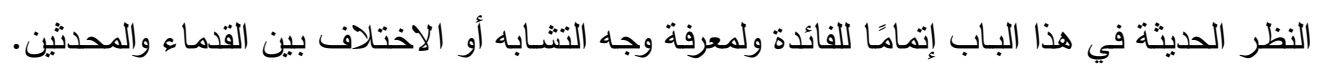

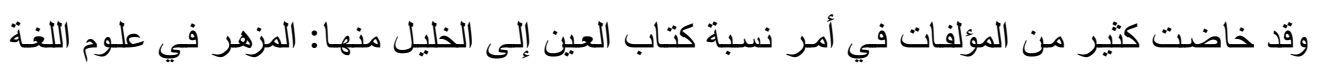

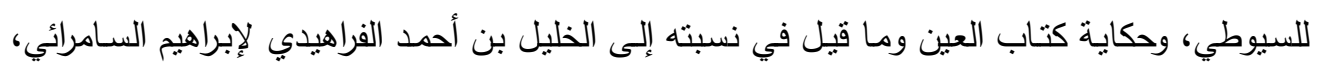

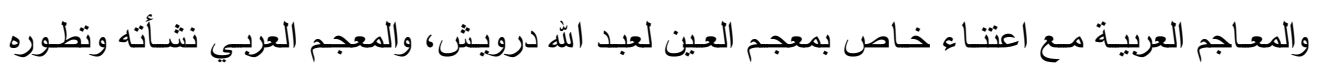

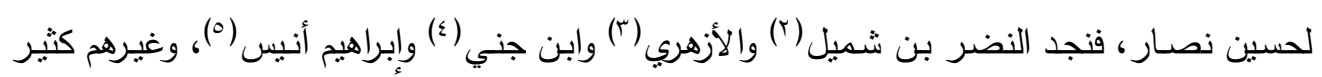

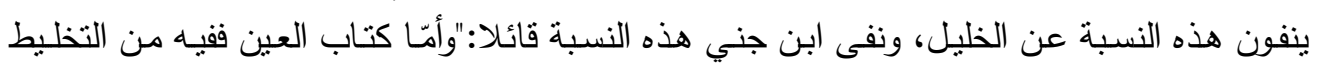

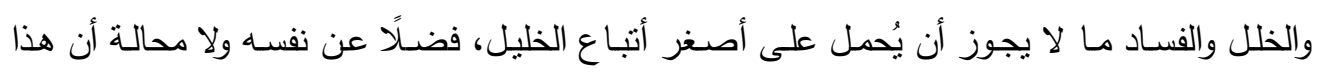

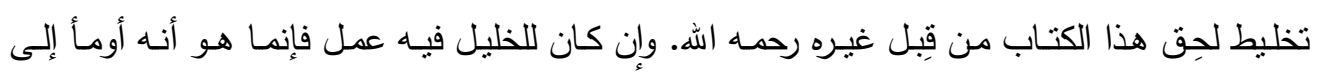

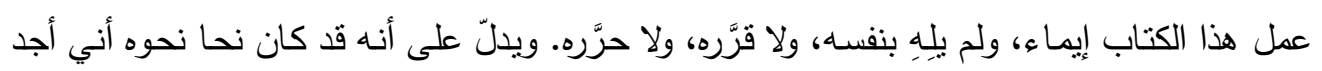

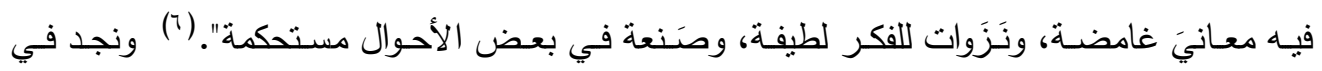

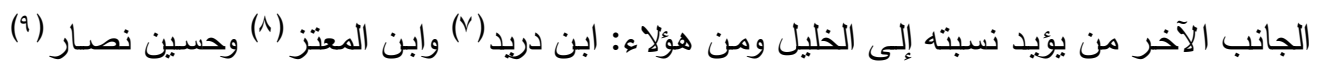

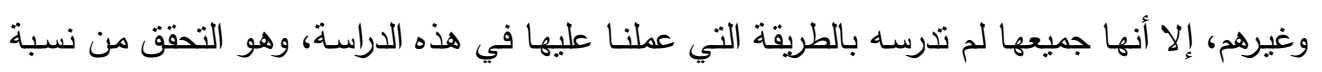

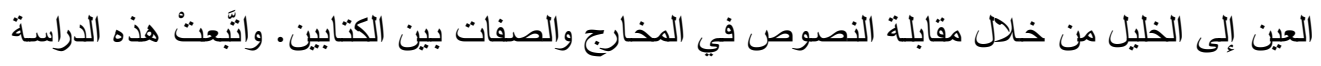

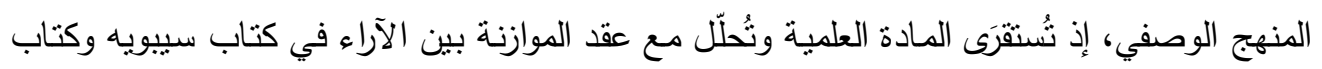


العـــــــــد السـابع والثلاثون

الجزء الثالث/ تشرين الثاني / 19

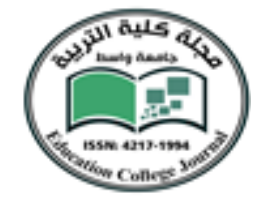

جامعة واسط

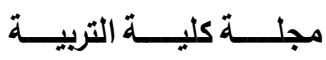

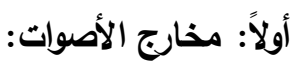

ذكر سيبويه حروف العربية قائلا: "فأصل حروف العربيّة تسعة وعشرون حرفا الهمزة والألف

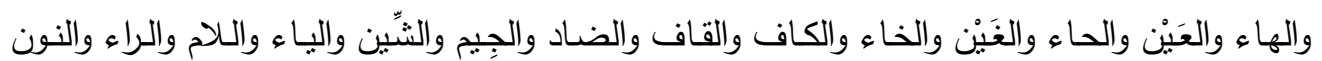

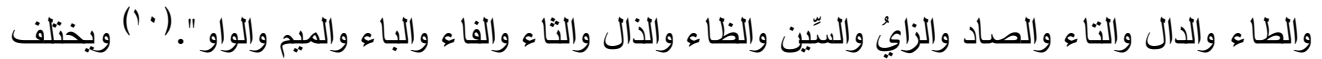

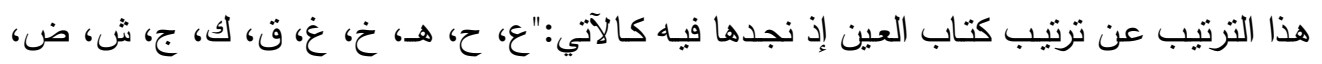

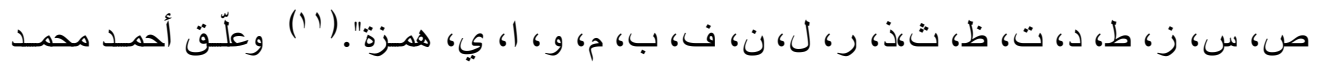
قدور على هذا قائلا:"بعض اللغويين القدامى جعل من هذا الترتيب الوارد في كتاب العين والمخالف

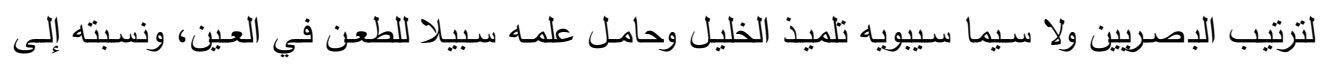

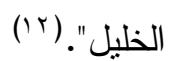

\section{أولاً: حروف الحلق:}

قسم سييويه الحلق إلى ثثلاثة أقسام لكل منها حروفه، فأقصساه للههزة والهاء والألف، وأوسطه للعين

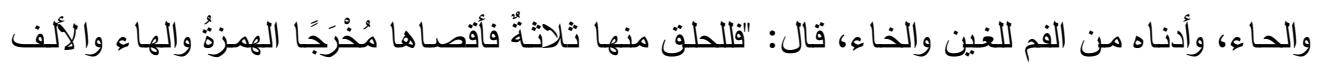

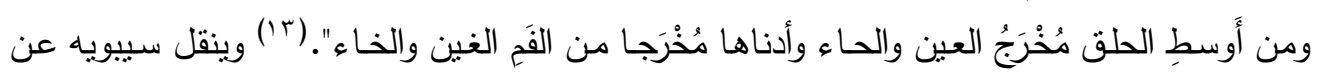

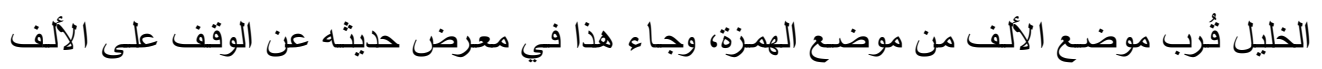

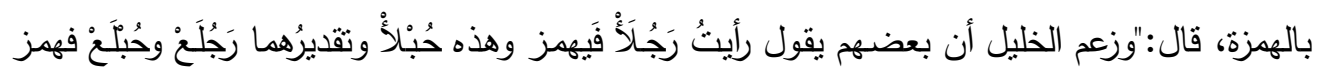
لقرب الألف من الهمزة حيث عَلِمَ أنه سَيصير إلى موضع الهمهزة فـأراد أن يَجعلها همزة واحدة وكان

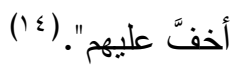

ويختلف موضوع أوائل وأقصى الحروف بين الكتابين، فصاحب العين يصرّح بأن حرف العين أقصى حروف الحلق ثم الحاء ثم الهاء ثم الخاء والغين:"قال الخليل: فأقصى الحروف كلها العين ثم الحاء

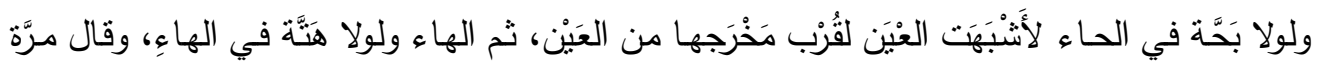

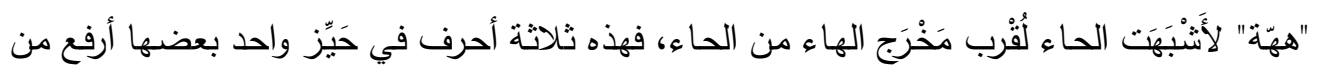
بعض ثُ الخاءُ والغَيْن في حيّز واحد كلَّهُنَّ حلقية". (10) كما نلاحظ اختلافًا بين الكتابين في مخرج كلٍ

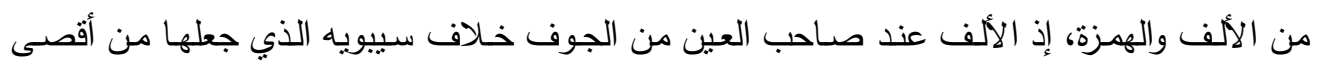
الحلق، أمـا الههزة فجعلها صساحب العين تارة من الجوف وتارة أخرى من أقصى الحلق، قال:"وأربعة

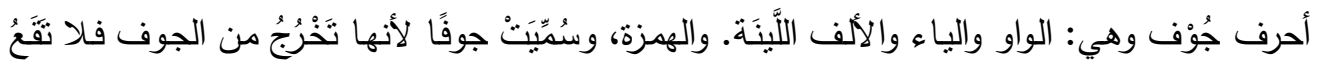


في مدرجة من مدارِج اللّلسان، ولا من مدارِج الحَلْقَ، ولا من مدرِجِ اللهاة، إنََّّا هي هاوية في الهواء فلم

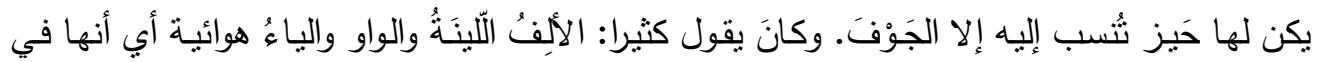
الهواء"(17)، والمقصسود بـ"كان يقول كثيرًا" هو الخليل وهذا لليل على أن مؤلف العبين ليس الخليل.

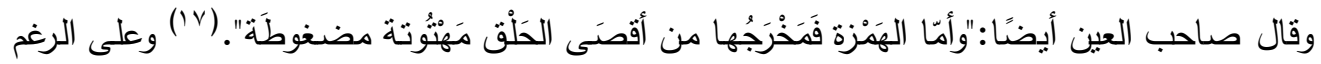

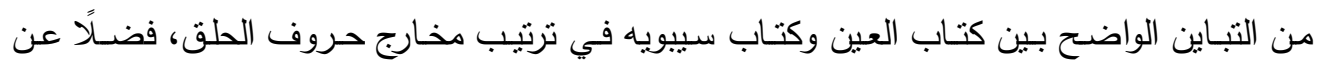
مخالفته في مخرج الألف والهمزة إلا أن سيبويه لم يُناقتشه.

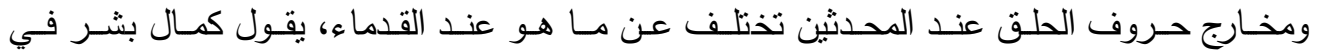
الخاء:"يرتفع أقصى اللسان حال النطق بهذا الصوت: بحيث يكاد يلتصق بأقصى الحنك وبحيث يكت بكون

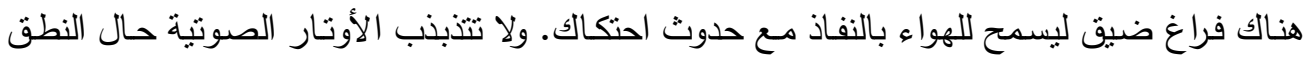

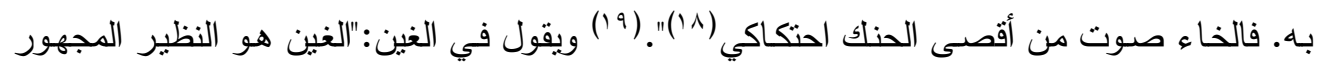

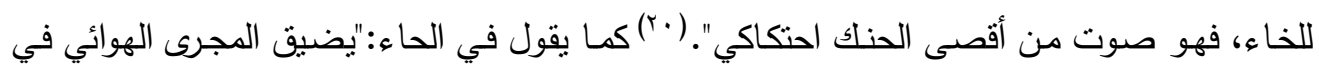

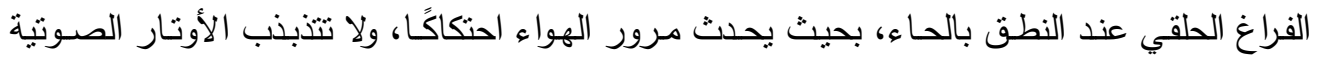

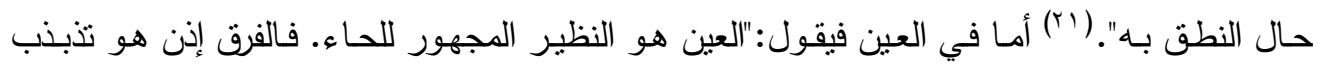

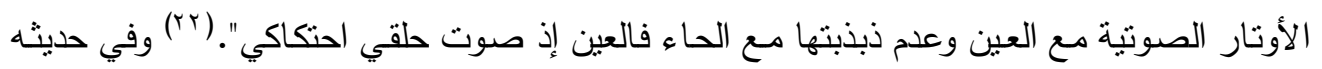
عن الهاء يقول:"تتكون الهاء العربية عندما يتخذ الفم الوضـع الصـالح لنطق حركة (كالقتحـة مثنال)

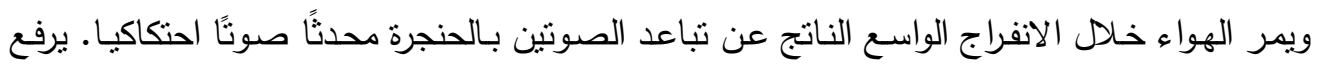

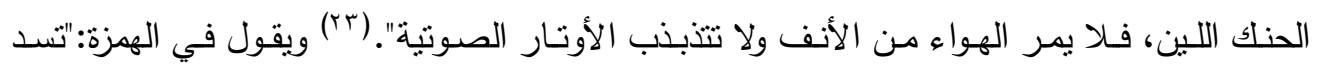

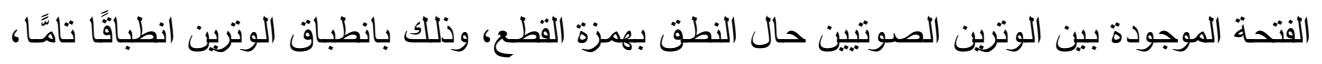

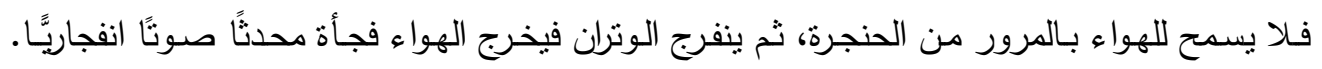

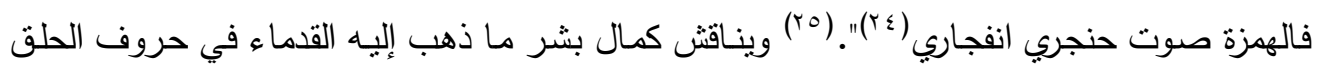

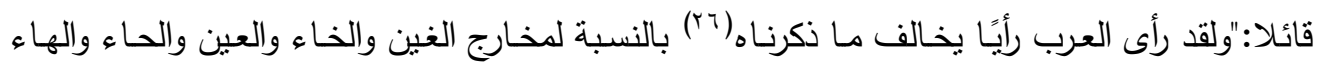

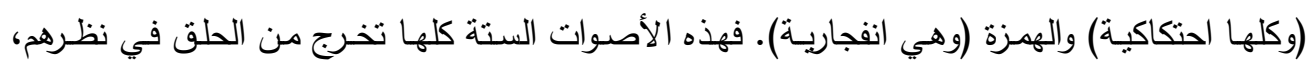

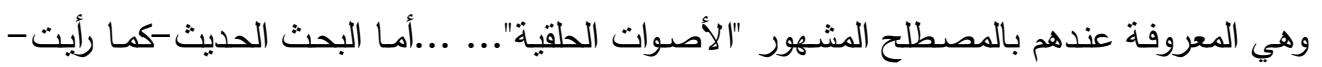

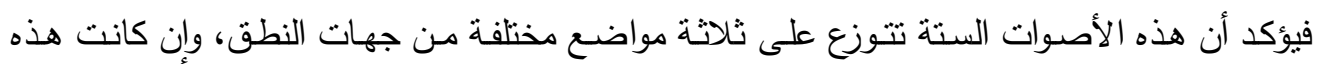

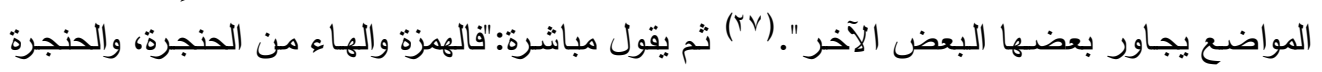

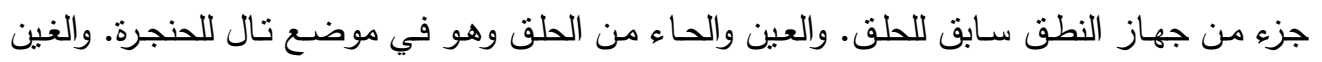


العــــــــد السـابع والثلاثون

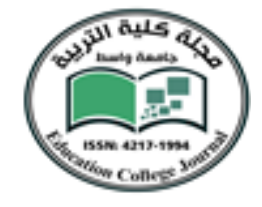

الجزء الثالث/ تشرين الثاني / 19

جامعة واسط

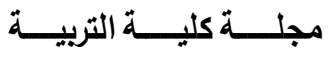

والخاء من أقصى الحنك وهو يقع في منطقة تالية للحلق من جهة الأمسام. ومعنى هذا أن الأصوات

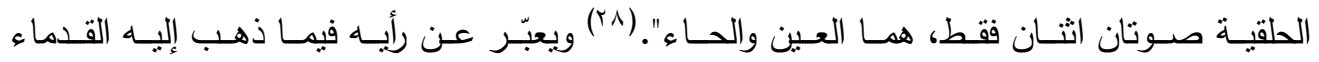

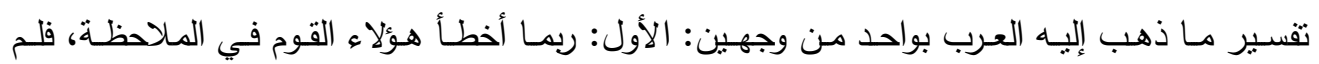

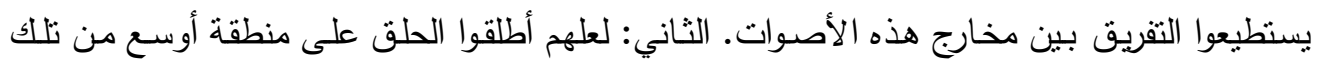

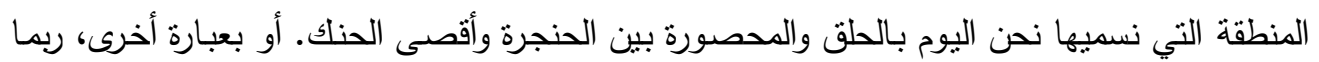

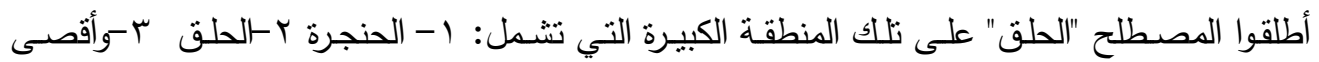

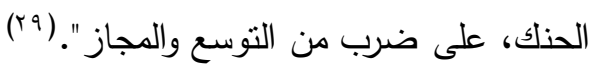

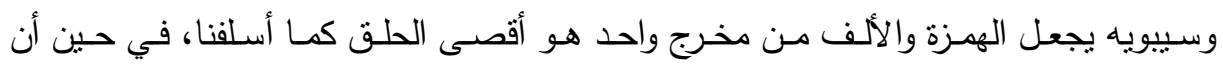
المحدثين"يفصلون بين الألف والهمزة، فينسبون الهمزة إلى فتحة الهزمار ، وينسبون الألف إلى مكان ما لها

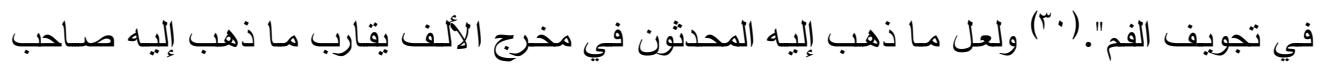
العين فيها ف"الألف ليس لها-في الحقيقة-نقطة إنتاج معينة على طول مجرى الهواء لأن اللسان يكون

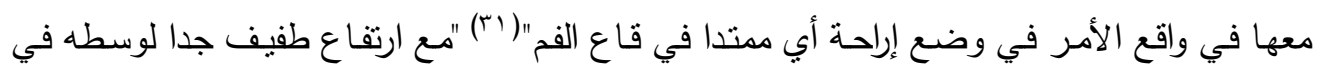

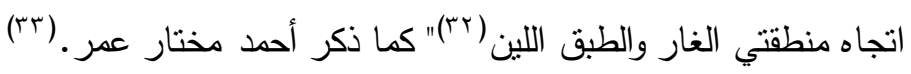

ومما تجدر الإثـارة إليه أن صـاحب العين قد جعل مخرج الهمزة تارة "من الجوف فلا نَّعُع في مدرجة

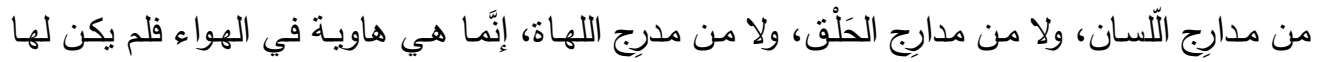

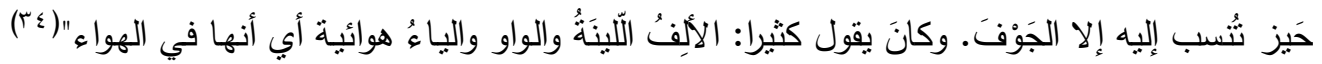

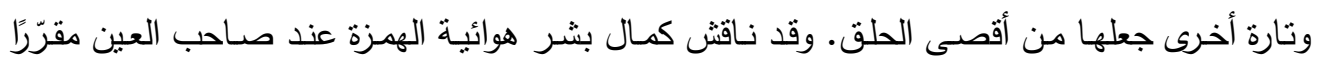

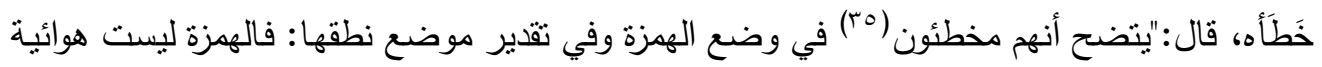

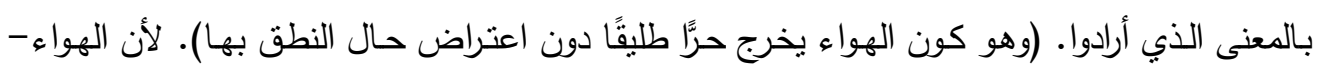

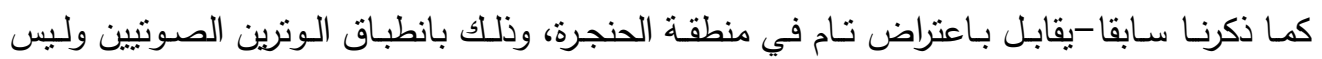

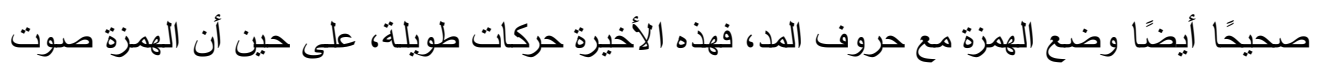

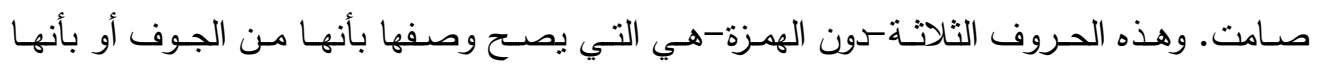

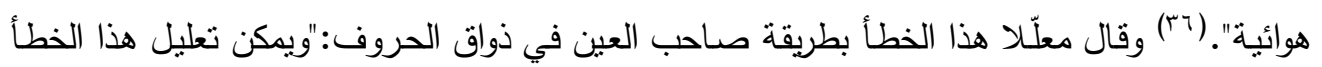

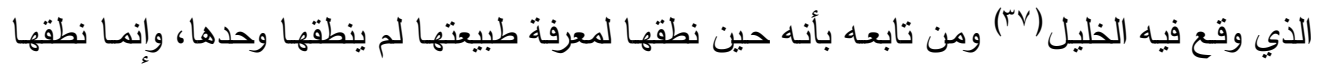

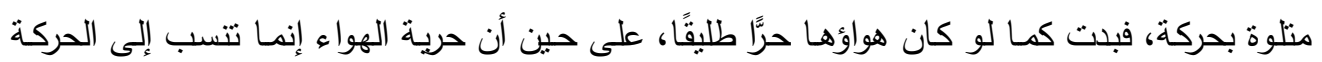

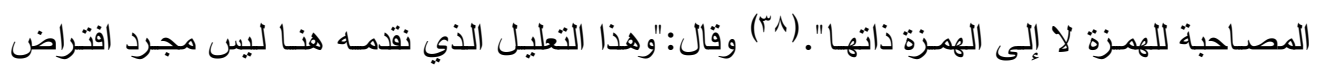




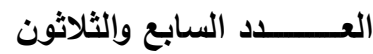

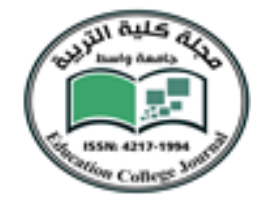

الجزء الثالث/ تشرين الثاني / 19

جامعة واسط

مجلـــــة كليـــــة التربيـــــة

وهمي، وإنما هو في حقيقة الأمـر يستتد إلى طريقة الخليل نفسـه في ذوق الحروف. فقد جرت عادة الخليل عند نطقه للحروف أن يفتح فاه بالألف (أي الهمزة) ثم يأتي بالحرف المراد نطقه ساكنًا هكذا:

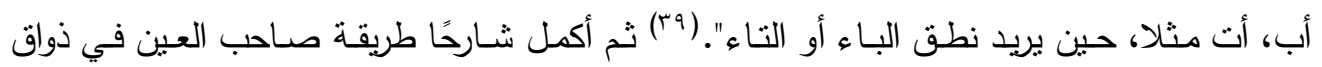
الههزة، قال:"ومعنـاه أنه في حالة نطق الههزة أتى بهمزتين: الأولى هي الههزة التي يـأتي بها مـع أي لي

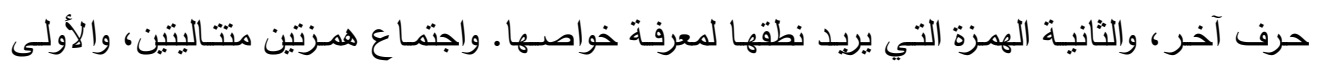

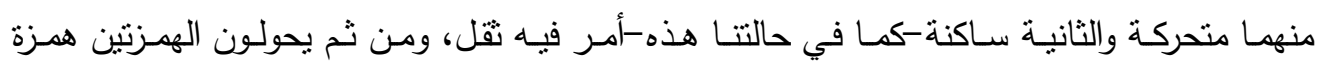
ممدودة [آ]. وهذه الهمزة الممدودة هي في واقع الأمر مكونة من همزة + ألف أي فتحة طويلة. فكان

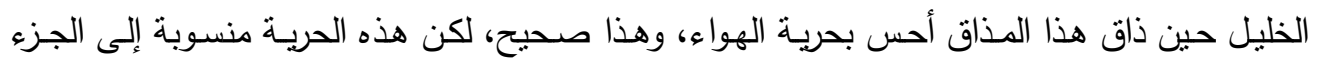

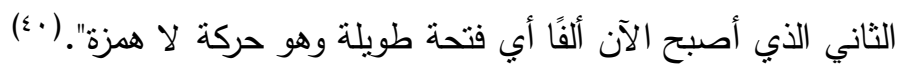
ويصف كمال بشر الهمزة عند صـاحب العين بأنها "مضطربة أشد اضطراب. إنه ينسبها إلى الهواء

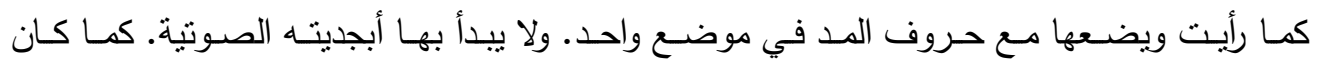

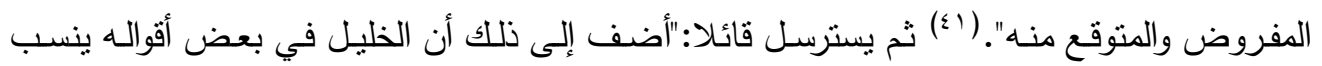

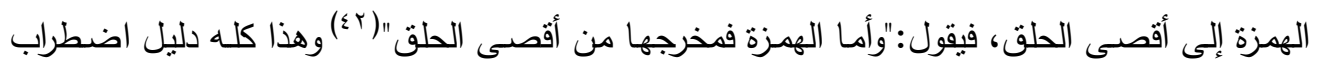
الرجل في إدراك طبيعة هذا الصوت وخواصهة". (r؟) ثانيًا: حروف اللسان:

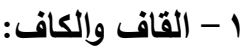

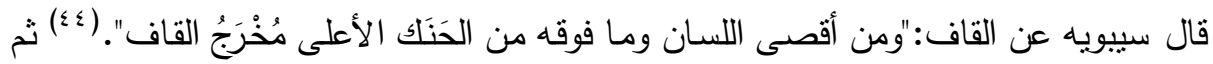

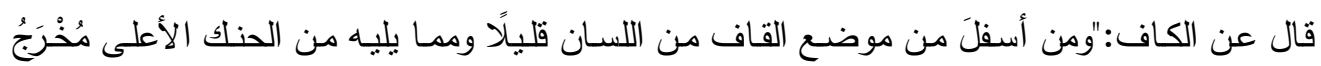
الكاف".(0؛) وفي كتاب العين جاء مخرج القاف والكاف من بين عكدة اللسـان واللهاة إلا أن الكاف

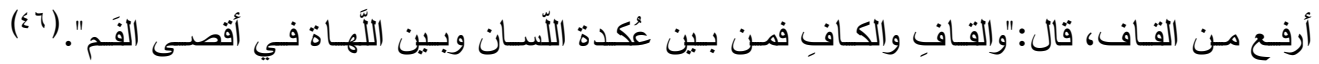

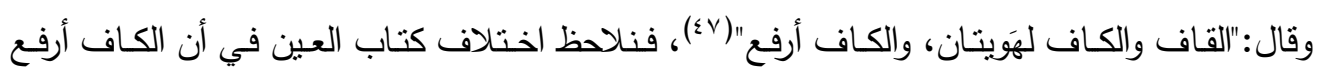
قياسًا بالقاف في حين هي أسفل من موضع القاف بوصف سيبويه. وقال:"القاف والكاف لَهَوِيتانِ، لأنَّ

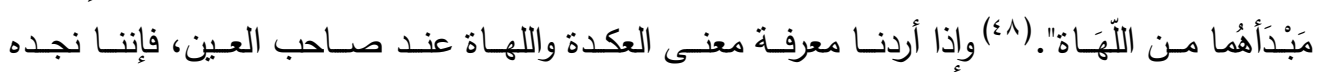

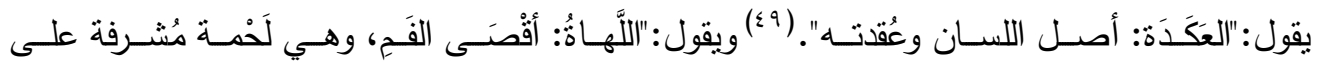
الحَلْقُ". (•) ونـلاحظ أن سيبويه لم يذكر اللهاة في كتابه، إلا أن عبد العزبـز الصيغ قد نبّه إلىى مـا 
يُقابلِها عنده، قال:"وقد حدد سيبويه هذا المخرج قائلا:"أقصى اللسان وما فوقه من الحنك الأعلى"( (0)،

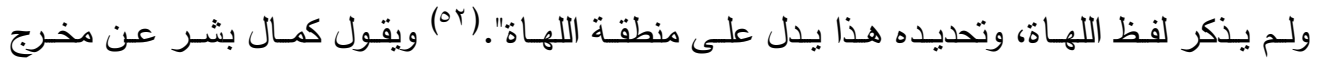

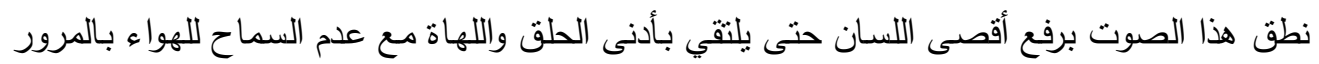

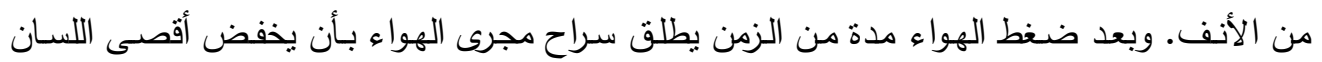

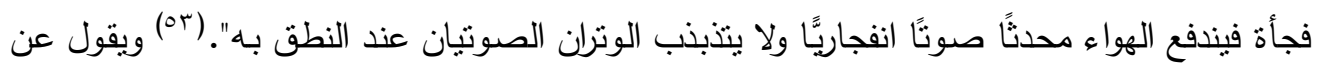

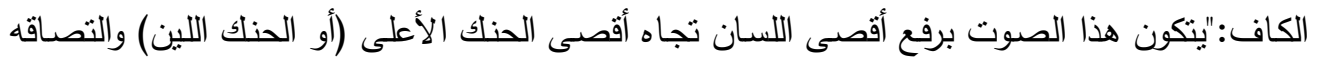

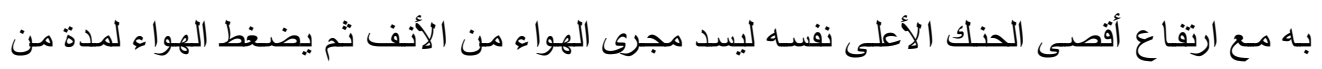

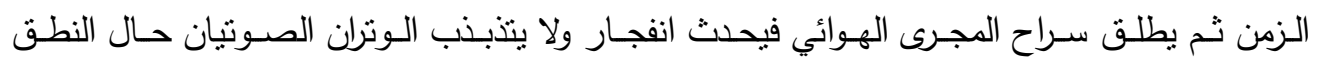

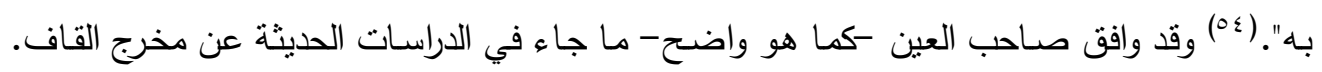

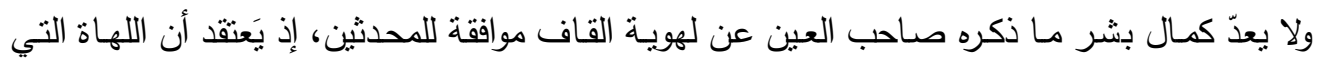

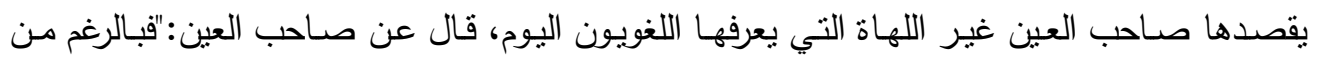
تصريحه بالوصف "لهوية" لا يمكن أخذ كلامه على أنه يقصد اللهاة بالمعنى المعروف لناه لنا، وإلا كان

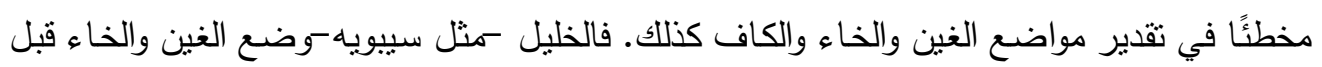

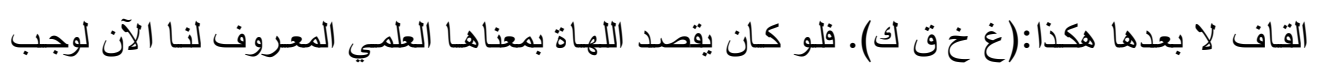

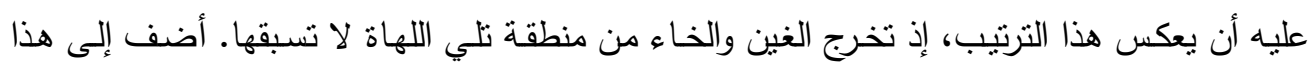

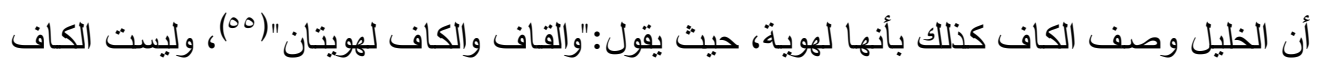

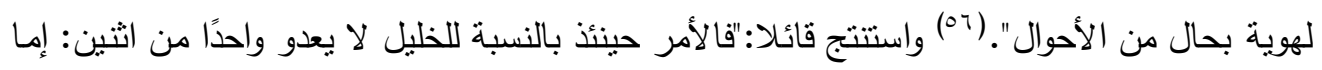

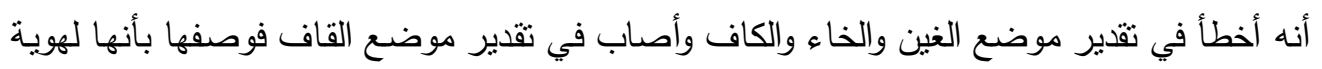

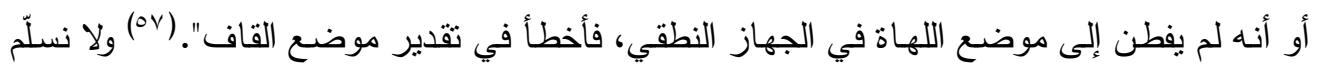

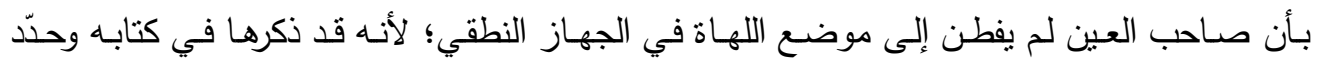

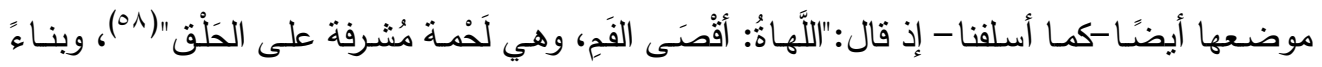

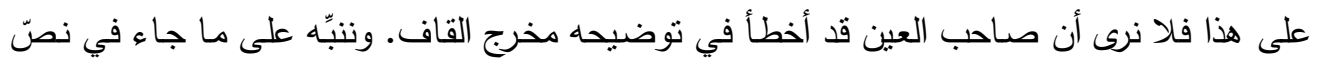

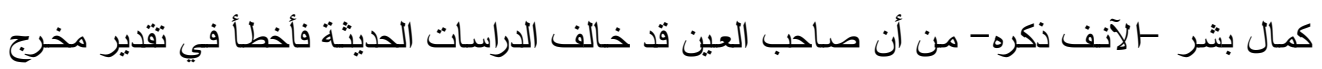

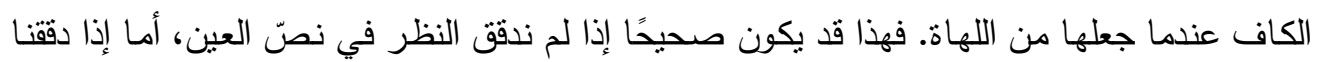

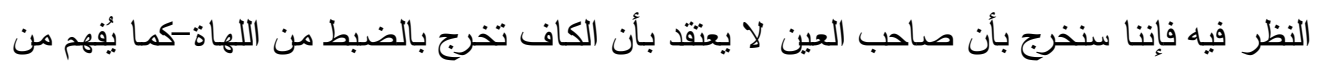

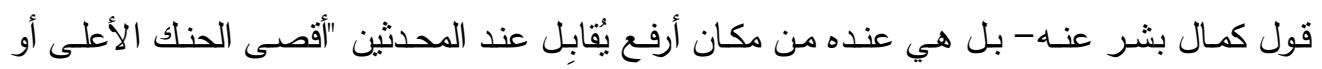

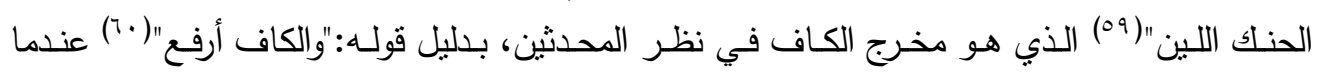


العــــــــد السـابع والثلاثون

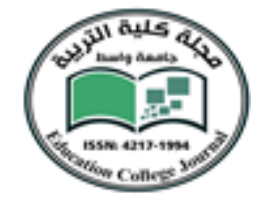

الجزء الثالث/ تشرين الثاني / 19

جامعة واسط

مجلـــــة كليــــــة التربيـــــة

قال:"القاف والكاف لهَويتان، والكاف أرفع".(") ويقول أحمد مختار عمر في عدِّ بعض اللغوبين القاف

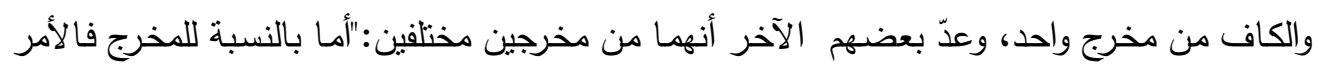

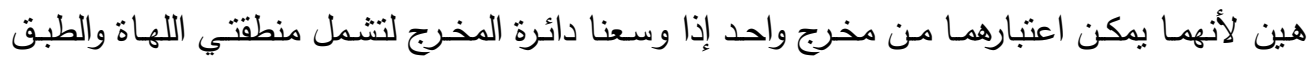
اللين المتجاورتين. كما أنهما يمكن اعتبارهما من مخرجين إذا فصلنا منطقة الطبق اللين عن منطقة

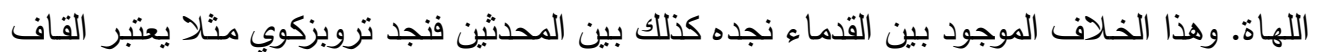
هي المقابل المفخم للكاف كاعتبار الطاء هي المقابل المفخم للتاء، وهذا يعني اتحاد مخرجهما. ولكننا

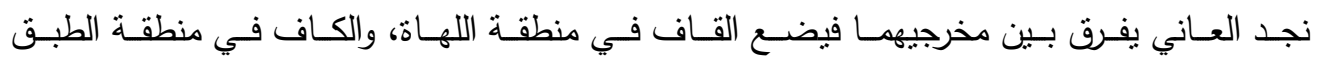
اللين (Tr)".) (Tr)

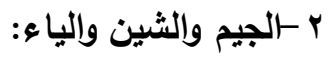

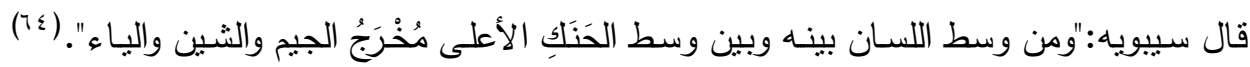

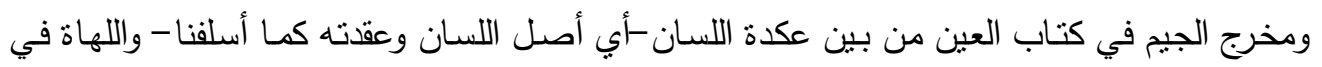

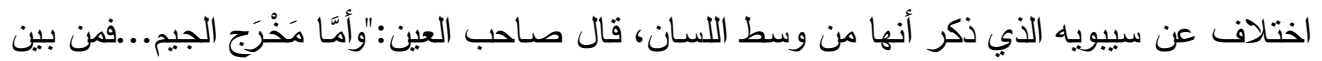

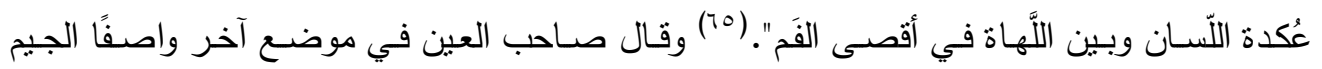

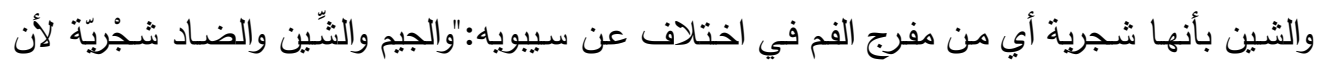

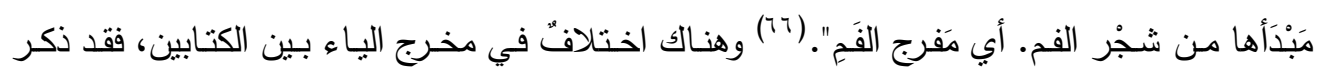

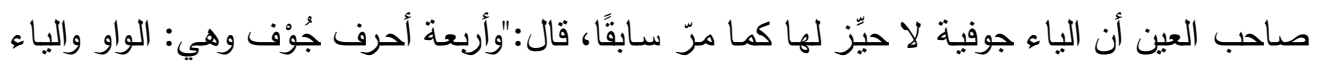

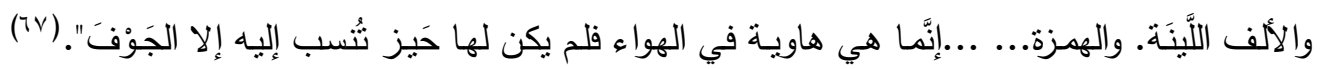

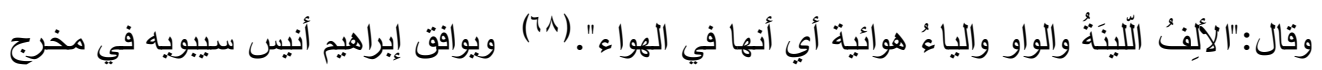

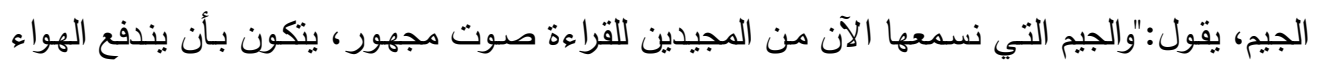
إلى الحنجرة فيحرك الوترين الصوتيين، ثم يتخذ مجراه في الحلق والفم حتى يصل إلى الـئى الدخرج، وهو

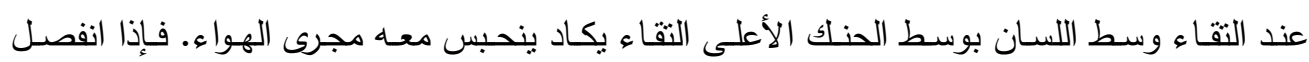

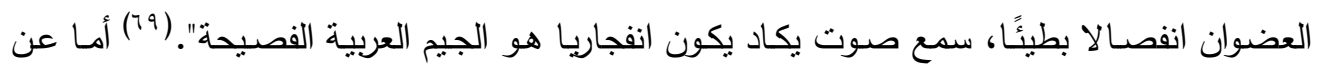

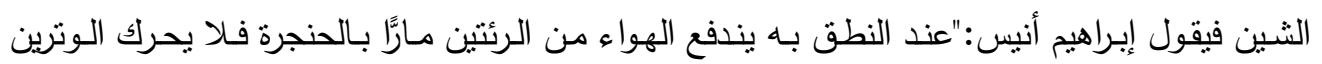

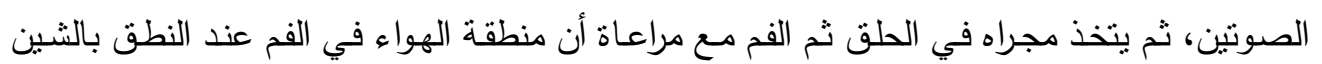

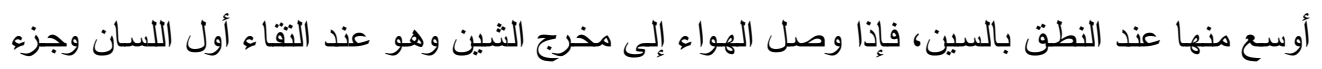

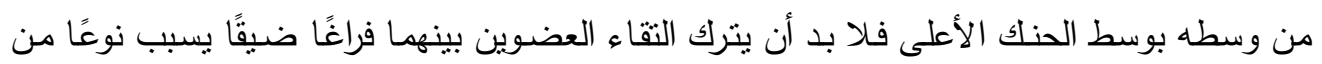


الصفير أقل من صفير السين؛ وذلك لأن مجرى السين عند مخرجها أضيق من مجرى الثبن عند

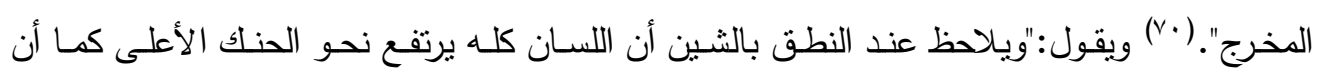

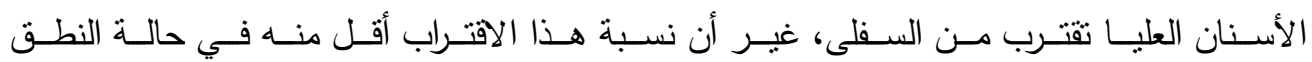

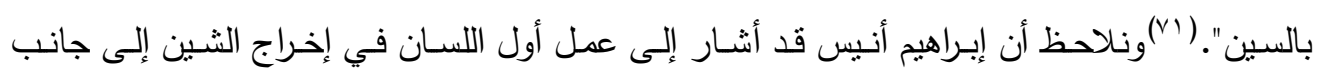

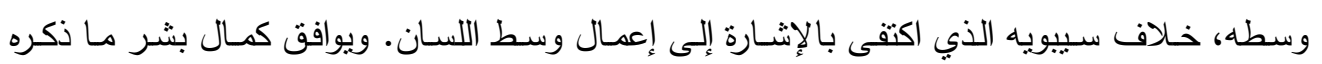

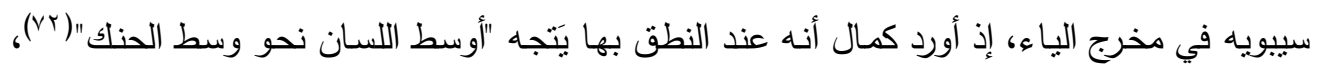

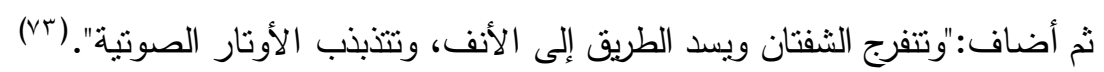
r- الضاد:

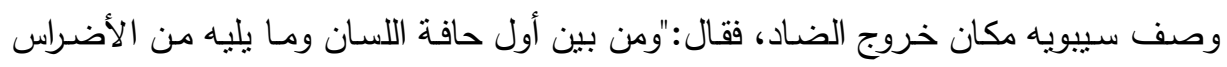

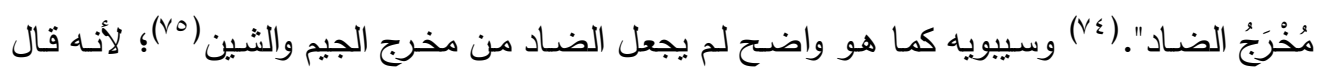

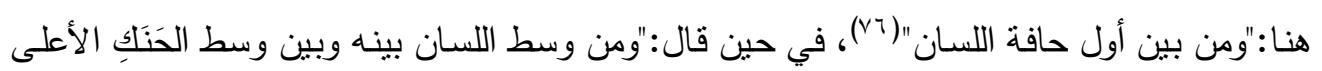

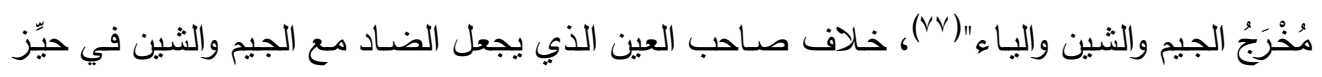

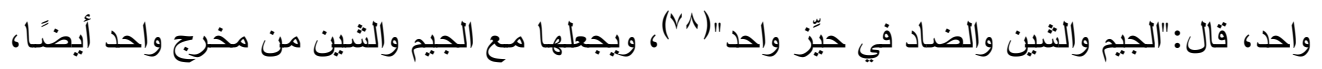

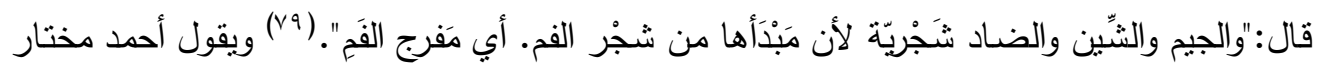

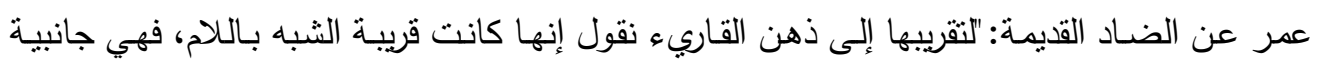

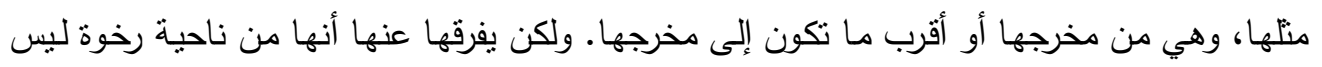

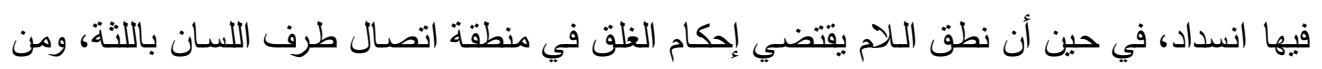

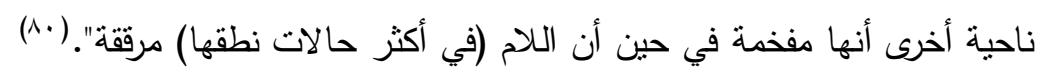

؛ - اللام والنون واللزاء:

قال سيبويه عن مخرج اللام والنون:"ومن حافة اللسـان من أدناها إلى منتهى طرَف اللسان مـا

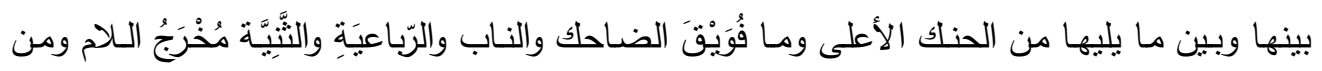

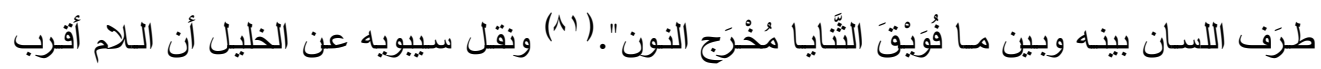

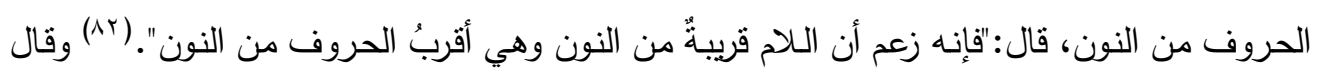

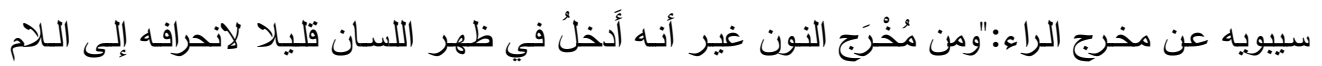

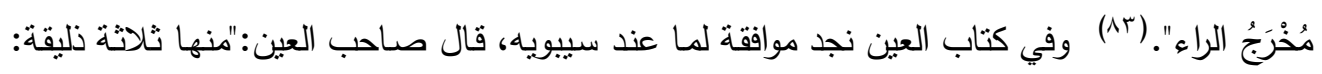




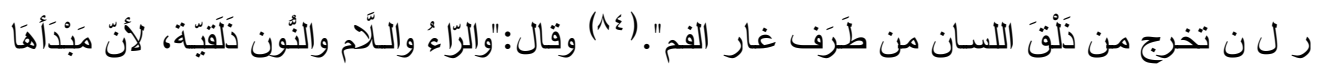

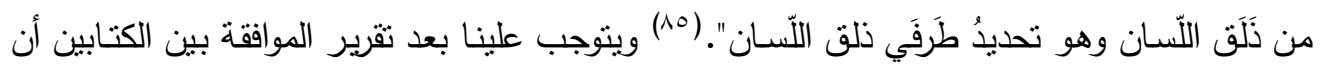

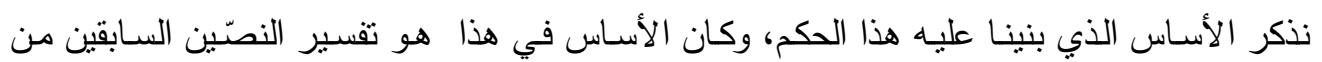

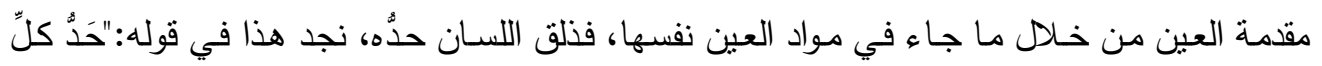

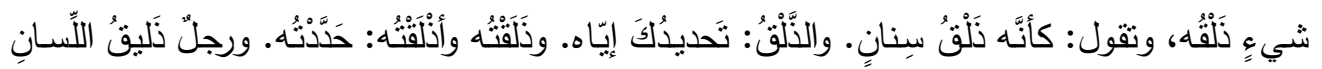

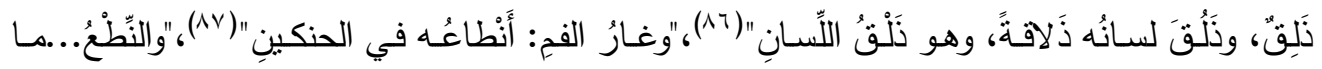

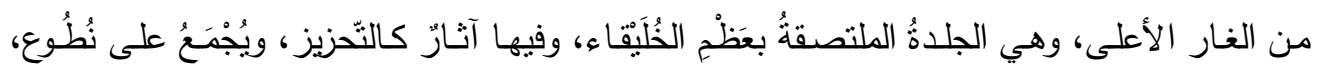

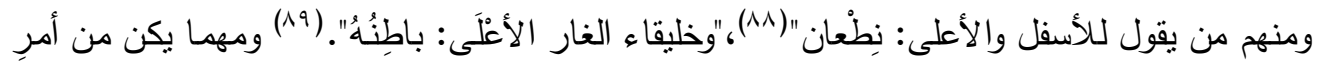

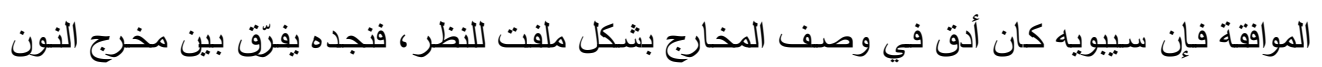

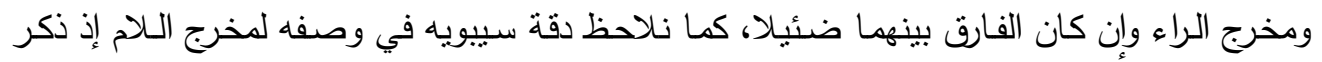

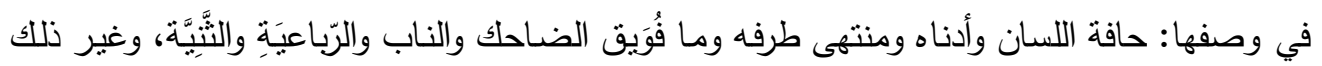

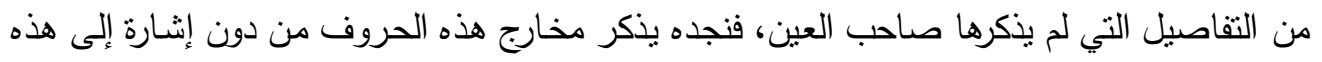

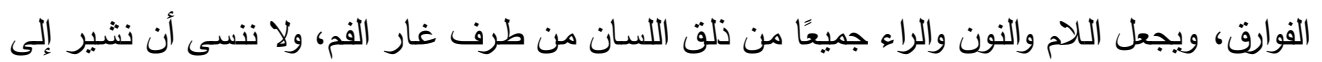

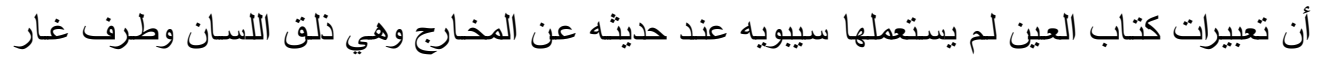

ومخرج الـلام والنون والـراء لا يختلف عند المحدثين عن مـا هو عند سييويه وصـاحب العين، قـال

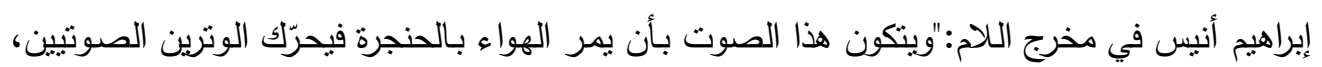

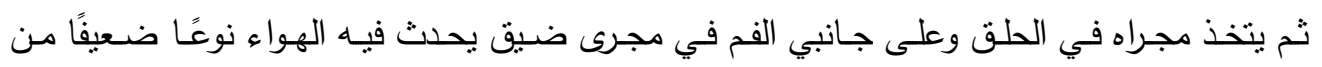

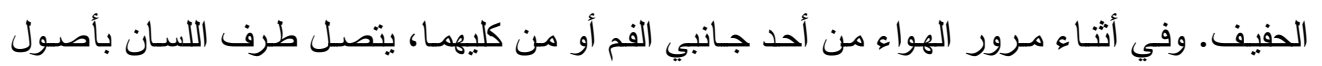

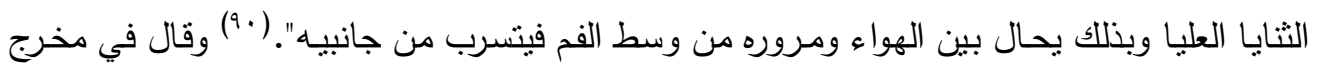
النون:"ففي النطق بـه يندفع الهواء من الرئتين محركا الوترين الصوتيين، ثم يتخذ مجراه في الحلق

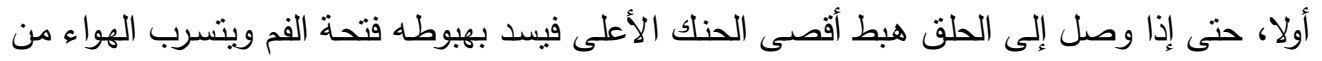

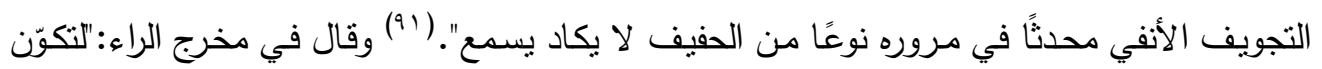

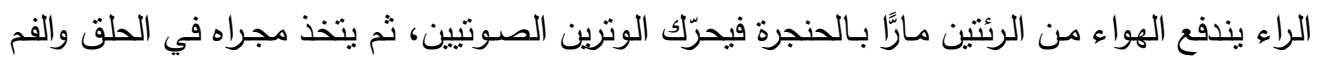

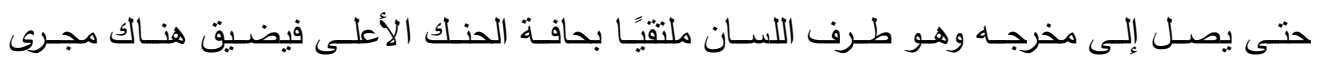


العــــــــد السـابع والثلاثون

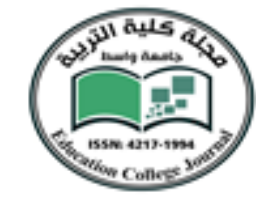

الجزء الثالث/ تشرين الثاني / 19

جامعة واسط

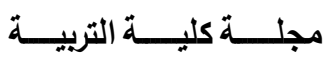

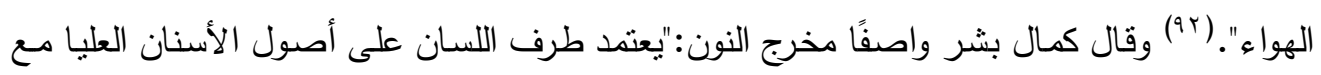

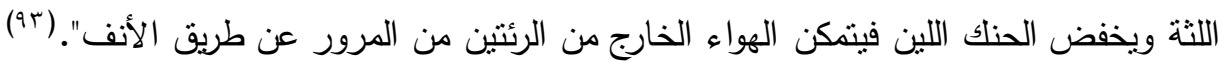

ه - الطاء والدال والتاء:

قال سيبويه في الطاء والدال والتاء:"ومما بين طرَف اللسان وأصول الثنايا مُخْرَج الطاء والدال

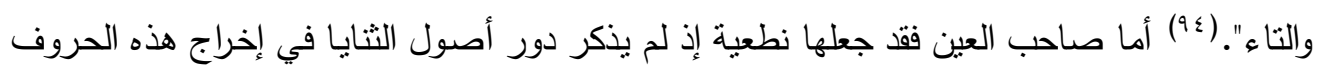

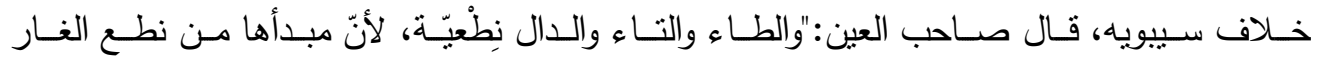

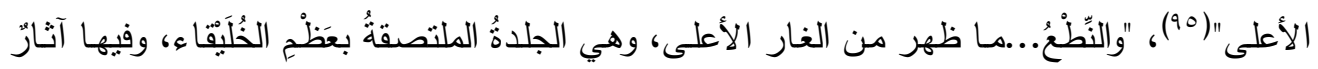

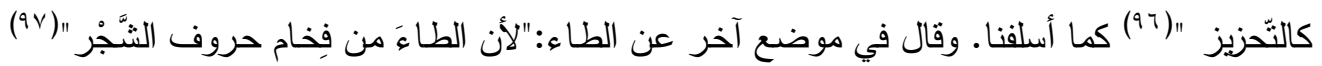

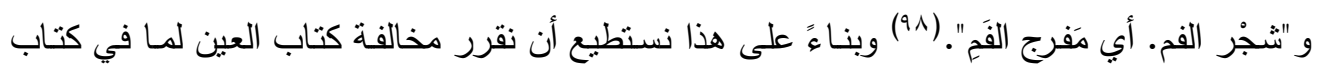

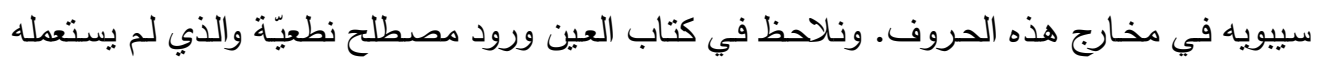

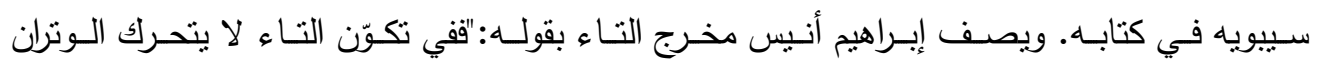

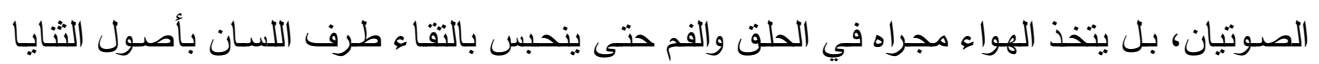

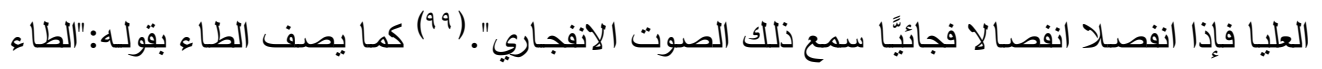

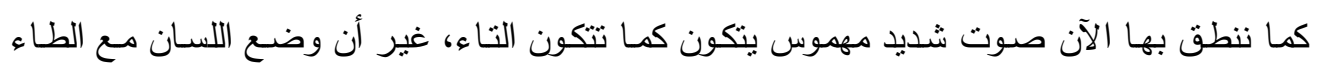

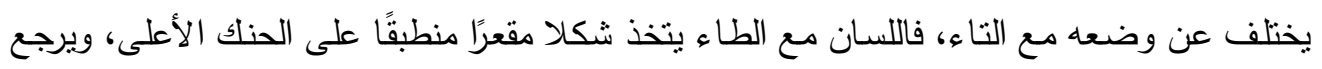

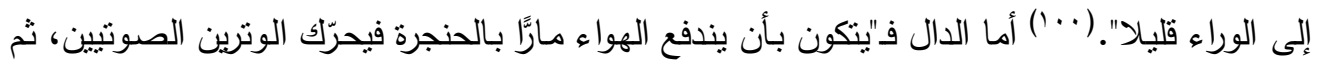

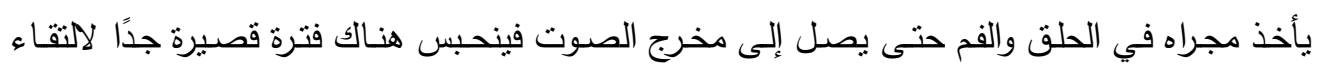

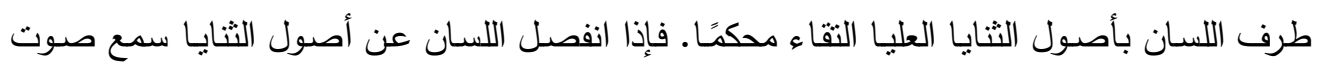

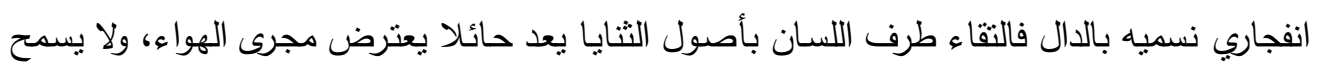

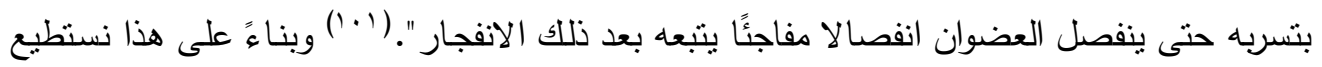

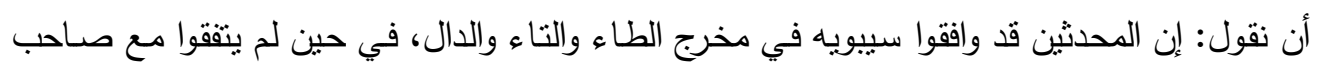

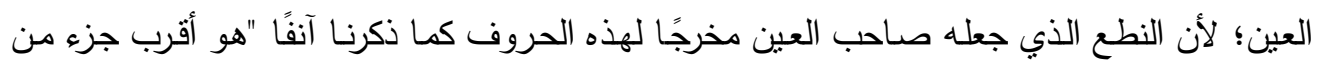

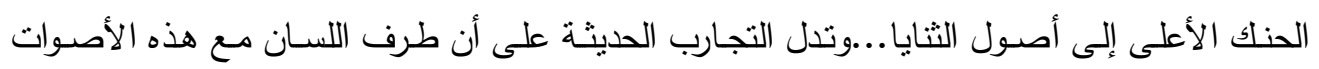

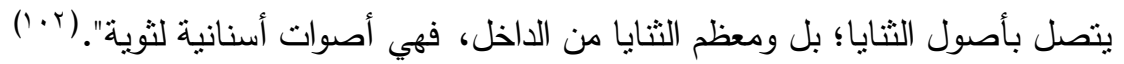


العـــــــــد السـابع والثلاثون

الجزء الثالث/ تشرين الثاني / 19

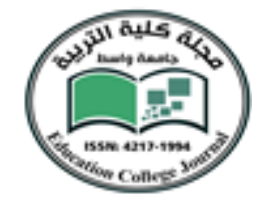

جامعة واسط

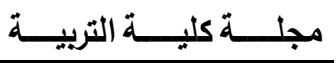

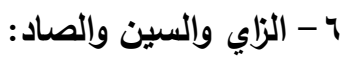

قال سييويه في الزاي والسين والصاد:"ومما بين طرَف اللسان وفُوَيَقِ الثنايا مُخْرَج الزاي والسين

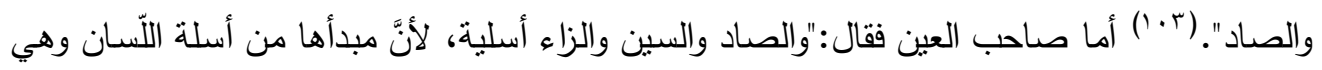

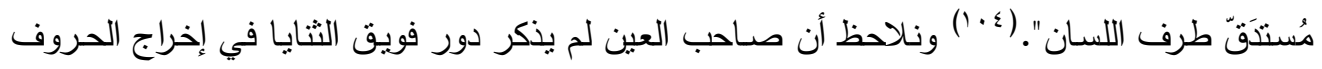

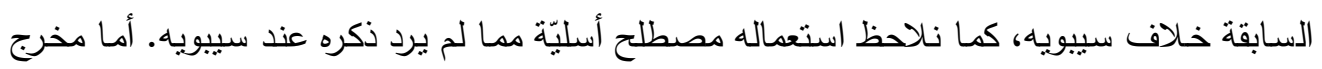

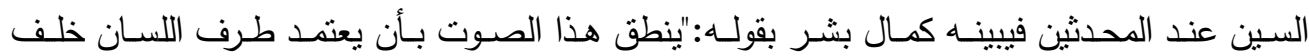

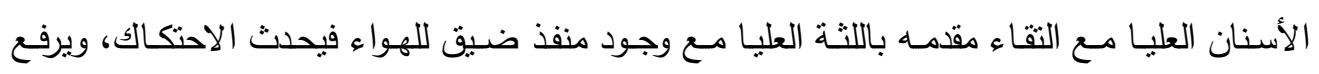

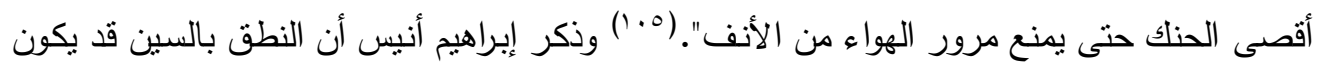

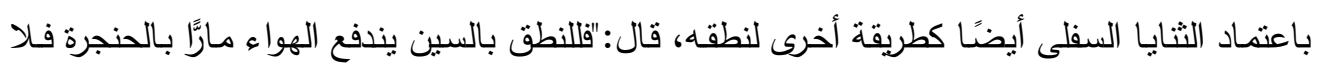

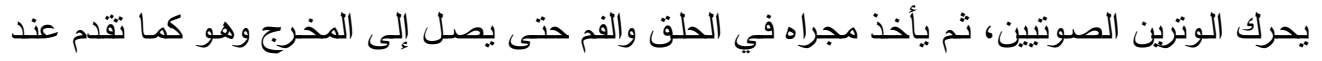

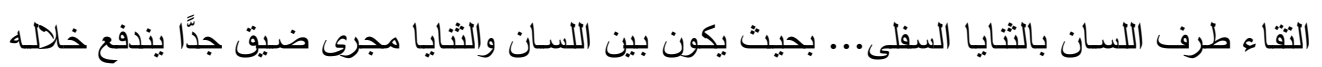

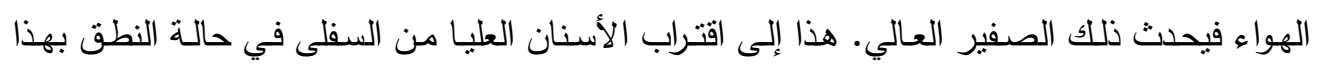

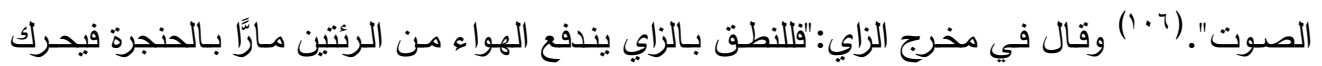

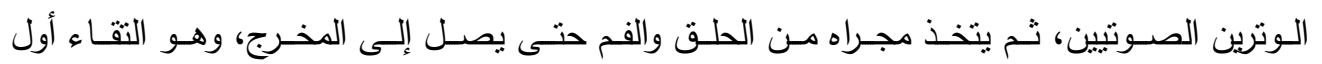

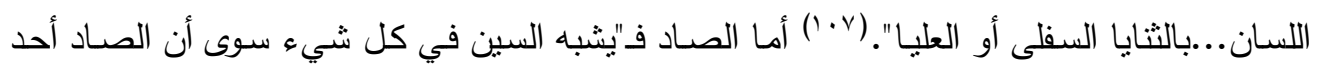

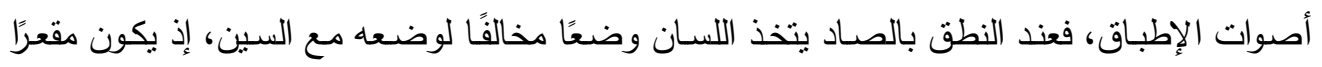

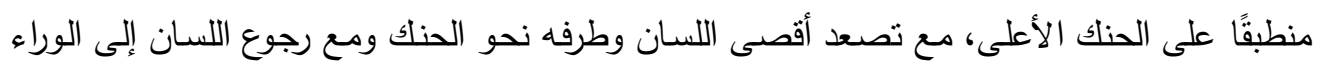

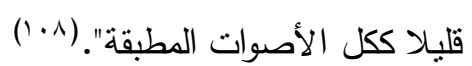

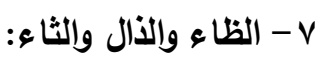

قال سيبويه في الظاء والذال والثاء:"ومما بين طرَف اللسان وأطرافِ الثنايا مُخْرَجُ الظاء والذال

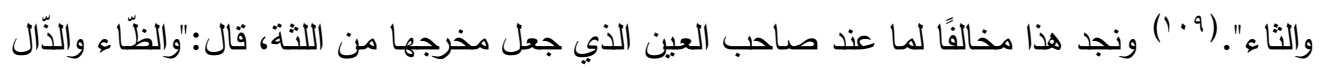

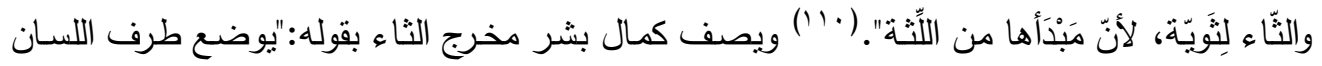

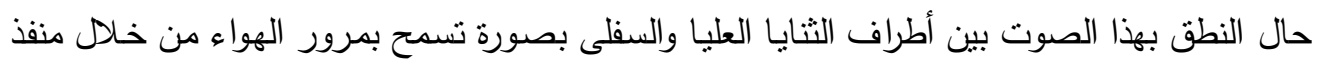

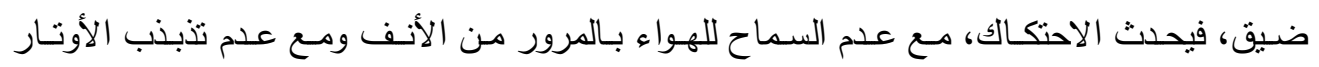

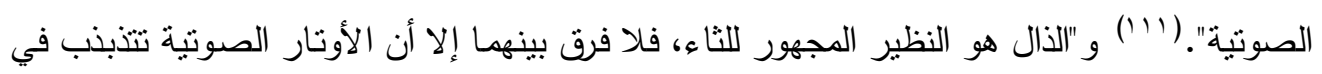

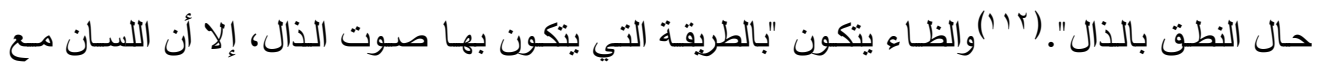




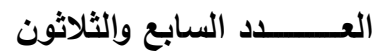

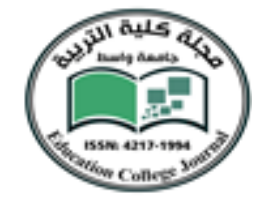

الجزء الثالث/ تشرين الثاني / 19

جامعة واسط مجلـــــة كليـــــة التربيـــــة

يرتقع مؤخره تجاه أقصى الحنك كما يرجع إلى الخلف قليلا فيحدث الإطباق (التفخيم) كما هو الحال

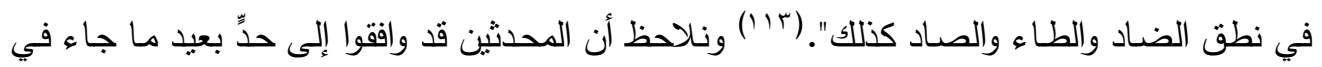
كتاب سييويه في مخرج الثاء والذال والظاء، في حين أنهح قد اختلفوا مـع مـا ذكره صساحب العين، عندما جعل مخرج هذه الحروف من اللثة على الرغم من أنسه لا دور لها فيهن، وقد ذهب المرعشي إلى أن اعتبارهن من اللثة كان مسامحة؛ لأن النفس عند نطق هذه الحروف ينتشـر فيتصل باللثة،

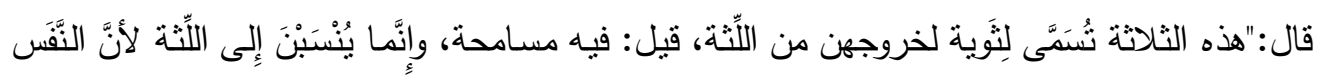
المصاحب لهذه الحروف ينتشر ويتصل باللّنة"( ع ا')، "إلا أن هذا الرأي يُعترض عليه بأنه أولى بعلماء

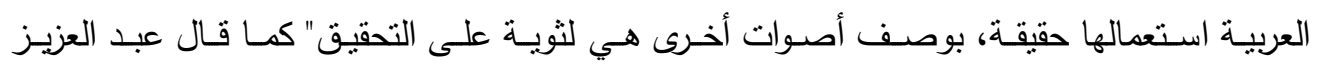

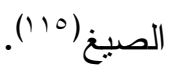

ثالثًا: حروف الشفتين:

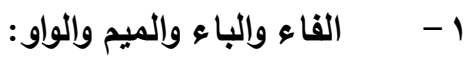

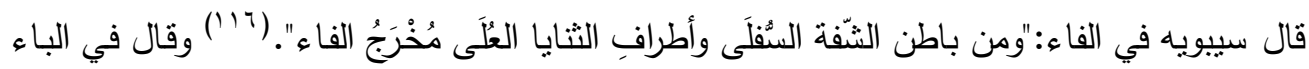

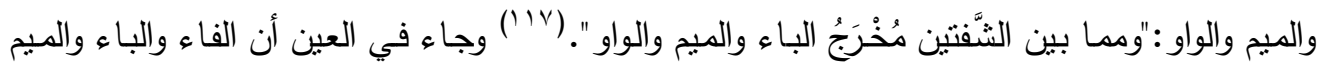
تخرج من بين الثفتين، وقد أشرك صاحبه كلا الشفنين في إخراج الفاء، ولم يحدد باطن الشفة السفلى

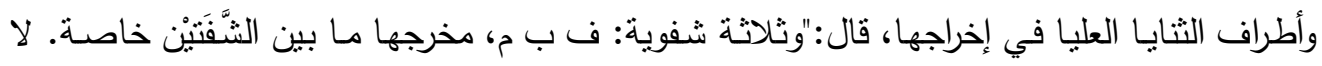

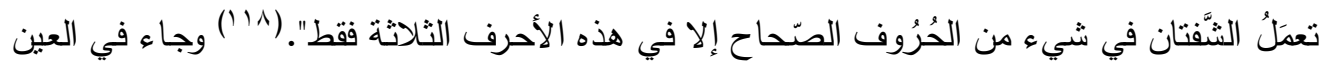

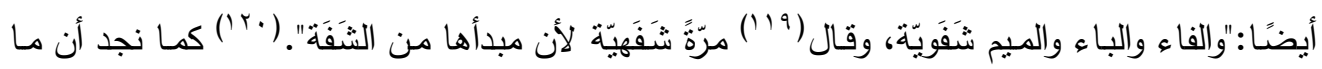
جاء عن مخرج الواو في كتاب العين يختلف عن ما هو عند سيبويه، إذ جعلها صاحب العين جوفية

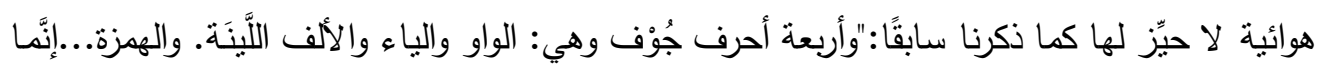

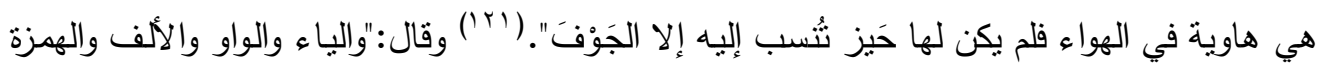

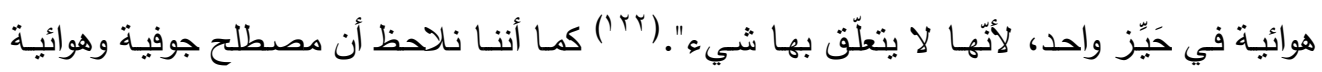
المستعملين في العين ليسا من المصطلحات التي استعملها سييويه في كتابه. ويوافق المحدثون سيبويه في مخـرج الفـاء إذ يُعِلِون أطـراف الثنايـا العليـا والشفة السفلى في إخـراج هذا الصـوت، قـال كمـال بثر :"يتم نطق هذا الصوت بوضع أطراف الثتايا العليا على الثفة السفلى ولكن بصورة تسمح للهواء

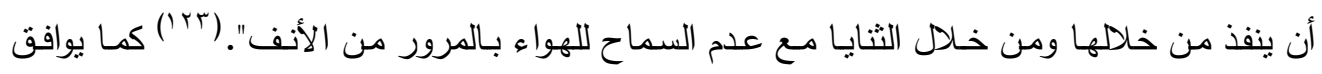
المحدثون سيبويه وصساحب العين في جعل مخرج الميم والباء من بين الثفتين، قال كمال بشر عن 


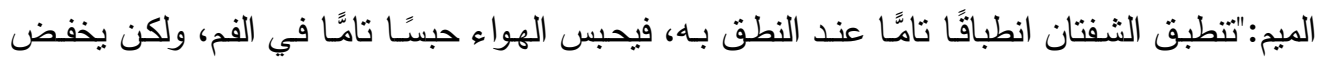

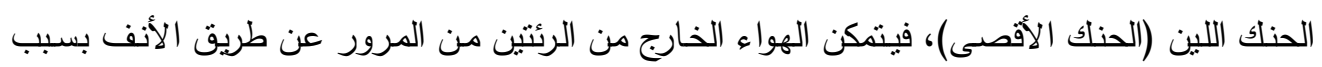

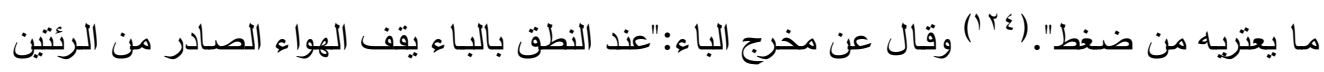

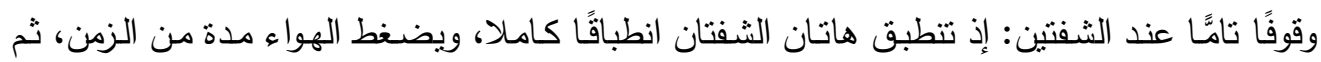

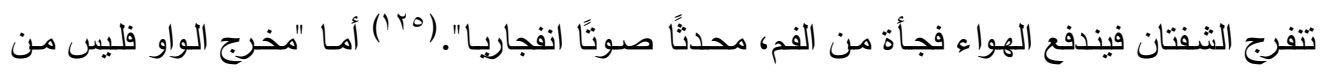

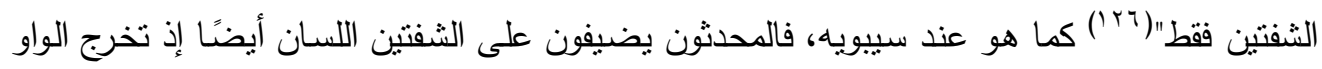

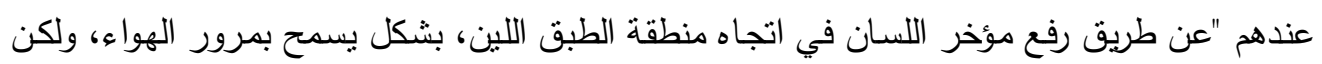

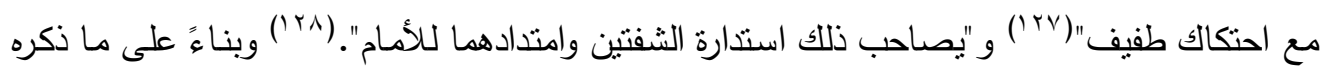

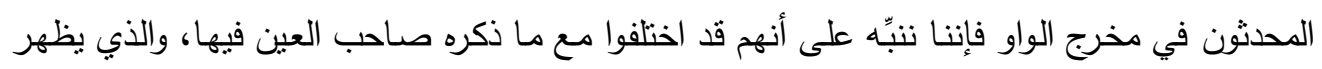

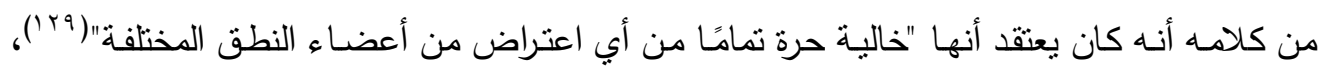

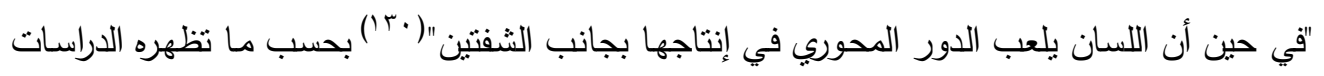
الحديثة. ومن خلال ما سبق نستطيع أن نخلص إلى أمرين: أولهها: أنه كما لم ترد مصطلحات العين في كتاب سيبويه من مثل : نطعيَّة وأسليَّة كذلك لم ترد

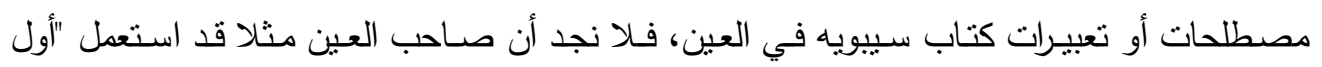

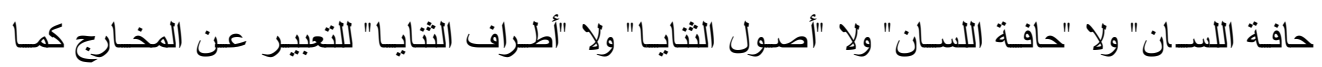

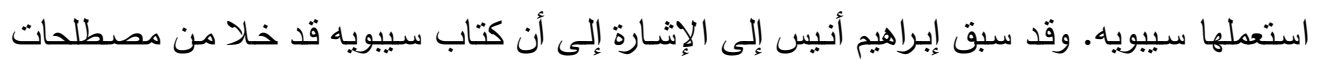

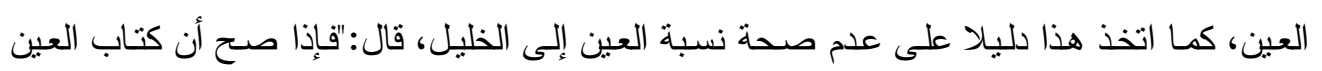

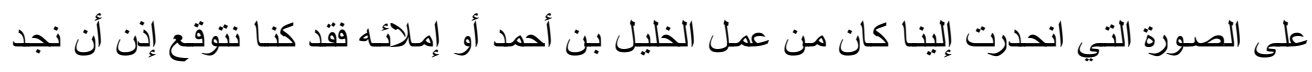

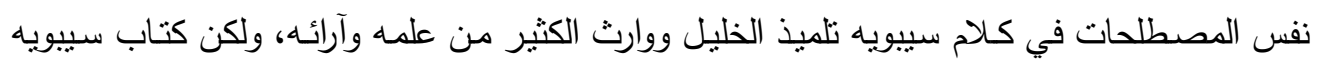

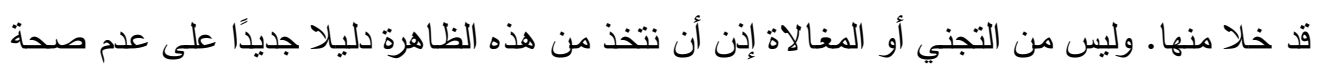

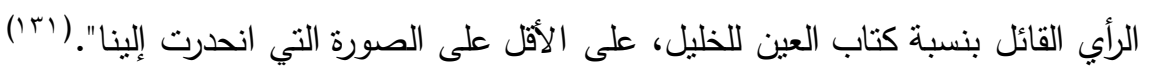

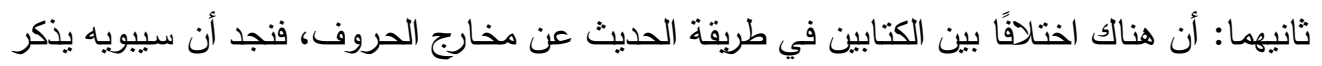

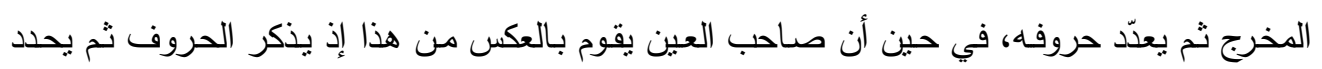
مخارجها. 
العـــــــــد السـابع والثلاثون

الجزء الثالث/ تشرين الثاني / 19

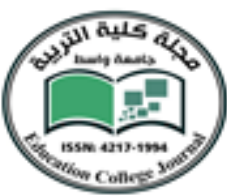

Cones 3
جامعة واسط

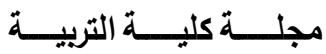

ثانيًا: صفات الأصوات:

بعد تحديد سيبويه مخارج الحروف نجده يتطرق إلى صفاتها، وقد صنفها بحسب الصفات إذ يذكر الصـفة ثم يُعدّد حروفها وقد يَرِد الحرف في أكثر من صـفة، وسـتكون دراسـة هذه الصـفات بموازنتها بما في العين، هذا من جهة، ومـن جهة أخرى سيكون في هذا المبحث صفات وردت في كتاب العين ولم يظهر صداها في كتاب سيبويه.

أولاً: صفات الأصوات في كتاب سييويه:

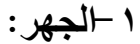

عرّف سيبويه المجهور بقوله:"فالمجهورة حرفُ أُشْبْعَ الاعتمادُ في موضعه ومَنَعَ النَّفَسَ أن يجري معسه حتى ينقضـي الاعتمـاد عليهه ويجري الصـوت فهذه حسالُ المجهورة في الحلْق والفَم إلا أن النـون

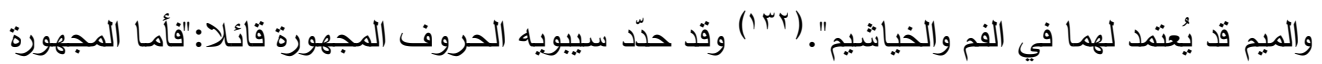
فالهزة والألف والعين والغين والقاف والجيم واليـاء والضـاد والـاحم والنون والراء والطاء والدال والزاي

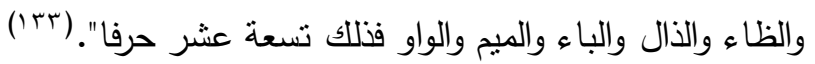

وفسّر إبراهيم أنيس هذا التعريف ذاكرًا معنى الاعتماد بقوله:""إنثباع الاعتماد" التي أراد بها أن يصف المجهور بأنه صوت متمكن مشبع فيه وضوح وفيه قوة، وتلك هي الصفة التي يشير إليها الأوروبيون

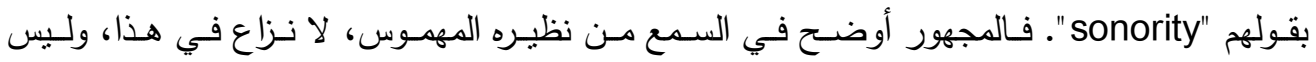
للاعتمـاد معنى في كـلام سيبويه سوى عملية إصدار الصـوت، تلك العملية التي تـلازم النفس منذ

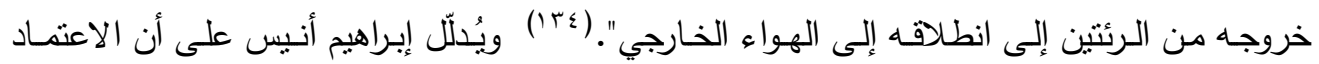

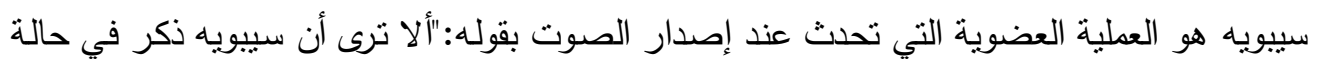

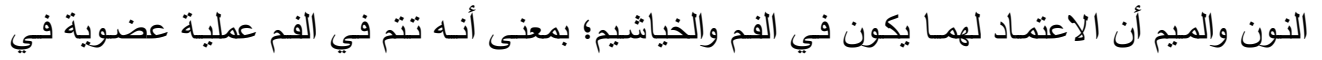
حالة هذين الصسوتين، وفي نفس الوقت تتن في الخيشوم عمليـة عضوية أخرى. فالنون تتكون بـأن يلتقي طرف اللسـان بأصسول الثنايا التقاء محكما، ويلتزم الناطق بها هذا الوضـع، غير أنسه في نفس

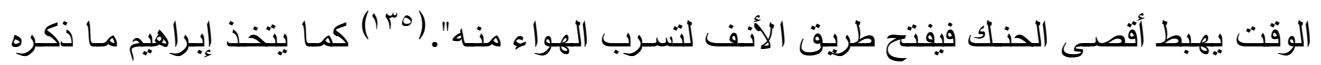
سيبويه في اعتماد المهموس دليلا آخر على أنه يريد بالاعتماد العملية العضوية، قال:"كذلك مما يدل

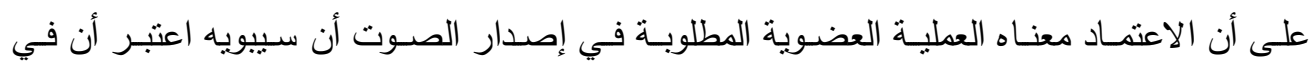
المهوس اعتمادًا أيضًا ولكنه اعتماد ضعيف، لأنه يقول:"فأمسا المهموس فحرف أضعف الاعته الاعتماد في 


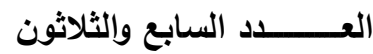

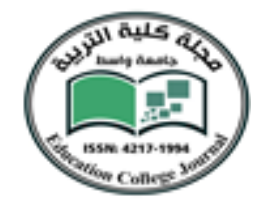

الجزء الثالث/ تشرين الثاني / 19

جامعة واسط مجلـــــة كليـــــة التربيـــــة

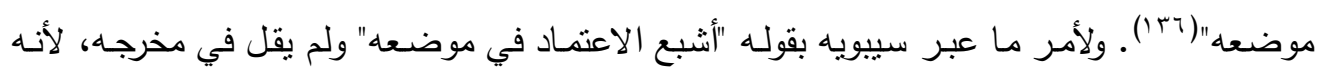
كان يشعر بهذا الإشباع في كل مجرى الصـوت منذ صدوره مـن الرئنين إلى انطلاقه إلى الخـارج،

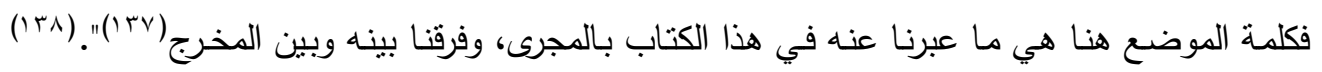

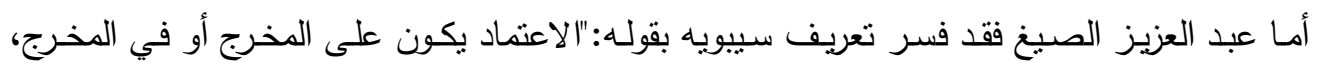

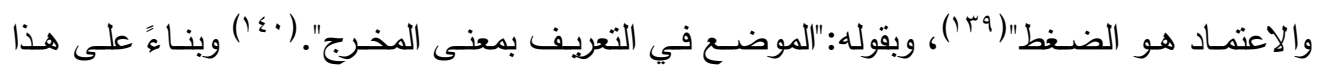

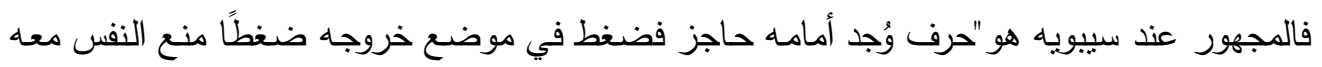
حتى يجري الصوت" على حدّ تعبير الصيخ.('أ) وينكر إبراهيم أنيس على من نحى هذا المنحى فهم عبارة سيبويه، قال:"وقد التبس الأمر على بعض الدارسين فحسبوا أن منع النفس مع المجهور هو ذلك إنك الانحباس المؤقت الذي يحدث مع الأصوات الشديدة، نلك لأن منع النفس مع المجهور عملية تنم في

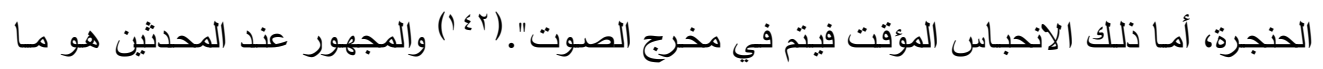
اهتزّت له الأوتار الصـوتية، قـال كمال بشر :"قد يقترب الوتران الصـوتيان بعضهما من بعض أثتاء مرور الهواء وأثناء النطق، فيضيق الفراغ بينها بحيث يسمح بمرور الهواء ولكن مع إحداث اهنزازات

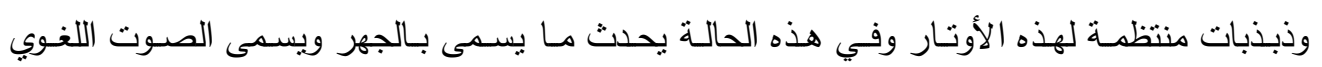

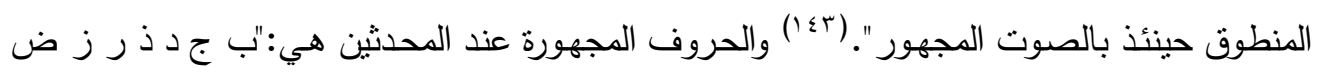

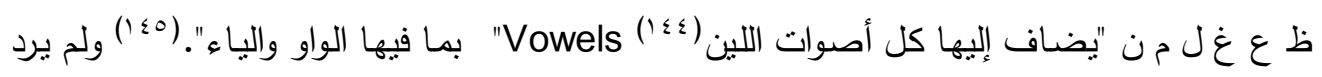
وصفُ للحروف في كتاب العين بأنها مجهورة، وإنما ورد الجهر بمعناه اللغوي، قال صـاحبه:"جَهَر

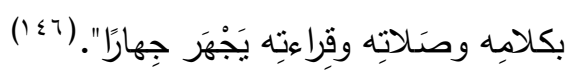

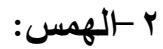

ذكر سيبويه الحرف المهموس بقولها:وأما المهموس فحرفُ أُضعف الاعتماد في موضعه حتى

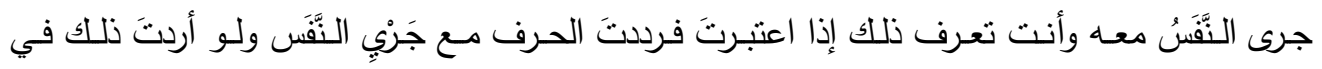

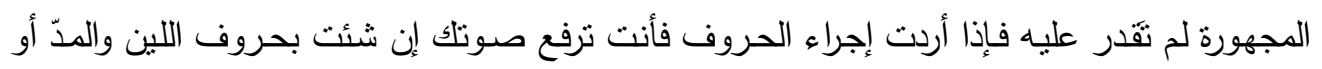

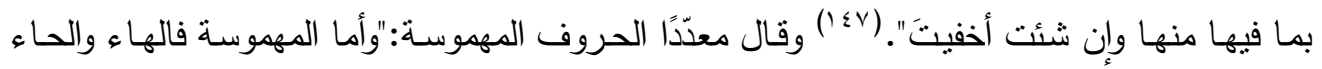
والخاء والكاف والثين والسين والتاء والصـاد والثاء والفاء فذللك عشرةُ أحرف". (^ءـ () ويفسر إبراهيم أنيس كلام سيبويه قائلا:"أمسا في حالة المهوس فقد عبر عنها سيبويه بضعف الاعتمـاد؛ أي عدم

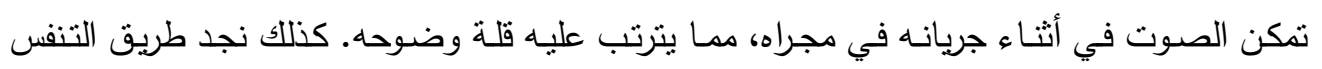
معهه مفتوحا بحيث يسمح بانسيابه حرًا طليقًا، وتلك هي الحال التي عبر عنها المحدثون بقولهم: إن 


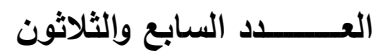

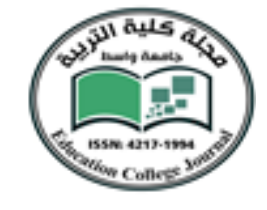

الجزء الثالث/ تشرين الثاني / 19

جامعة واسط

مجلـــــة كليـــــة التربيـــــة

الوترين الصـوتينين مـع المهـوس يبتعد أحدهما عن الآخر فينطلق النفس مـن بينهــا دون حاجـة إلى

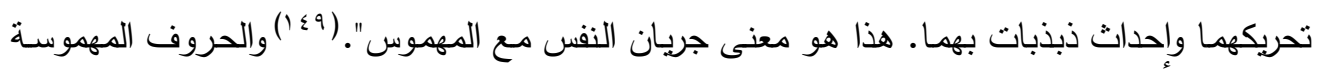
عند المحدثين هي:"ت ث ح خ س ش ص ط ف ق ك هـ".(10) وقد "اختلف المحدثون في فهم كلام

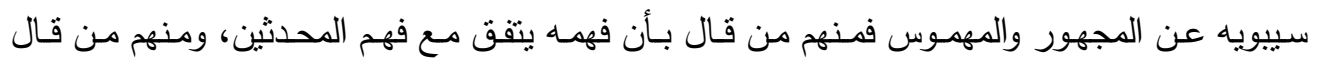
يختلف، فمن قال يتفق فسر ذلك بأن سيبويه وإن كان لا يعلم بوجود الوترين الصوتيين إلا أنـه أدرك

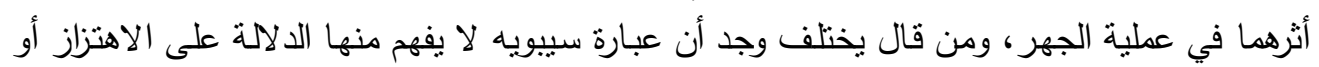

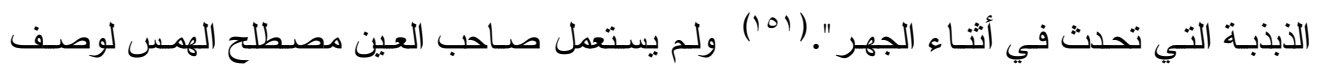

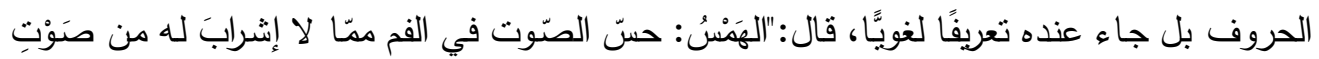

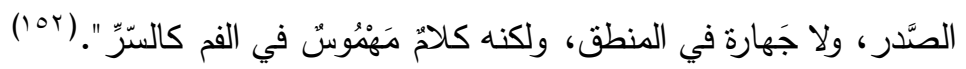

بالشَّدَّة:

قال سيبويه في الحروف الثديدة:"ومن الحروف الشديذُ وهو الذي يمنع الصوت أن يجري فيه وهو الهمزة والقاف والكاف والجيم والطاء والتاء والدال والباء ونلك أنك لو قلت أَلْحَج ثم مددتَ صوتلك

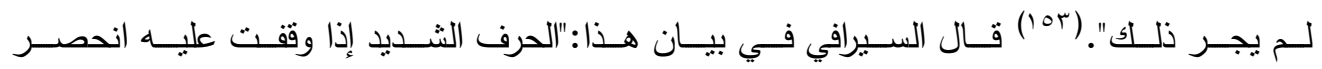

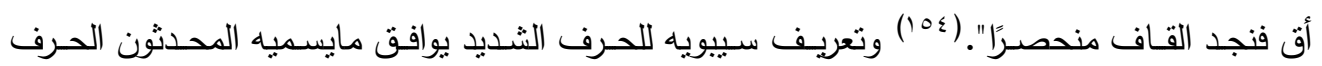

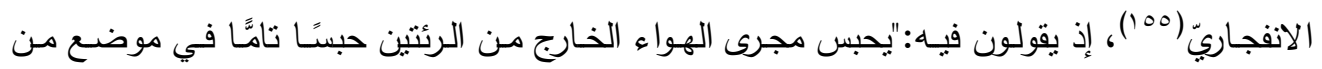

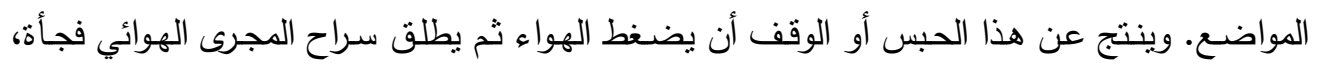
فيندفع الهواء محدثًا صونًا انفجاريًّا"(107)، "وتجدر الإشارة إلى أن تصنيف سيبويه للأصوات الثديدة

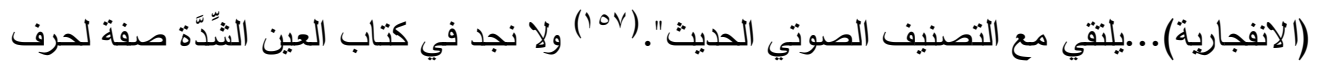

$$
\text { ع - الرَّخاوة: }
$$

قال سييويه عن الحروف الرِّخوة:"ومنها الرِّخْوةُ وهي الهاء والحاء والغين والخاء والثين والصـاد والضاد والزاي والسين والظاء والثاء والذال والفاء، وذلك إذا قلت الطَّنْ وانْقَضْ وأشباه ذلك أجريتَّ فيه الصوت إن شئت".(101) وشرح السيرافي هذا بقوله:"الرخو إذا وققت عليه لم ينحصر الصوت...تقول: إث أو أخ فتجده جاريًا".(109) وجربان الصوت الذي ذكره سيبويه هو تسرب للهواء كما أشنار إبراهيم

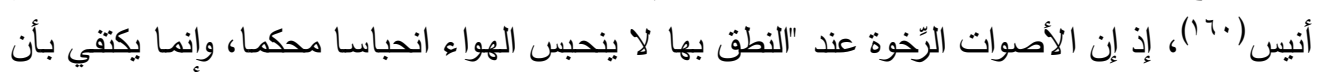


يكون مجراه عند المخرج ضيقًا جدًا ويترتب على ضيق المجرى أن النفس في أثناء مروره بمخرج

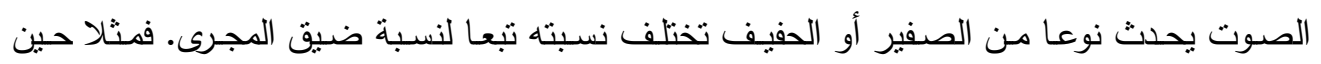

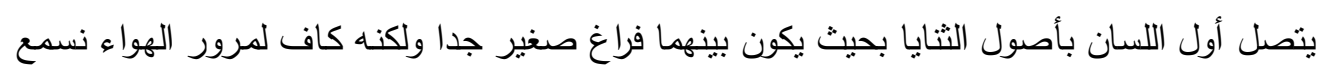

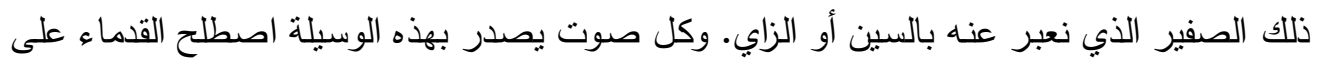

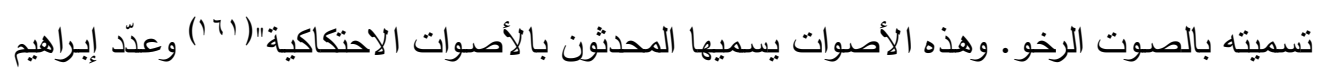

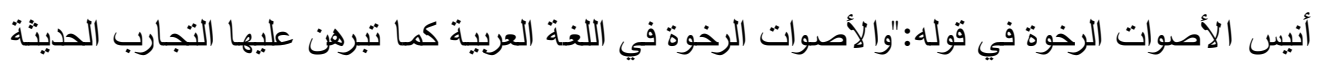

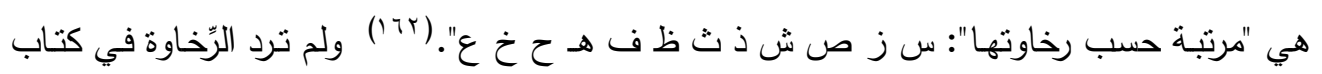
العين صفة للحروف.

\section{ه - ما بين الرِّخاوة و والثَّدَّة:}

وصف سيبويه حرف العين بأنه بين الرَّخاوة والثندِّة، قال:"وأما العين فبينَ الرَّخْوة والثنديدة تصل

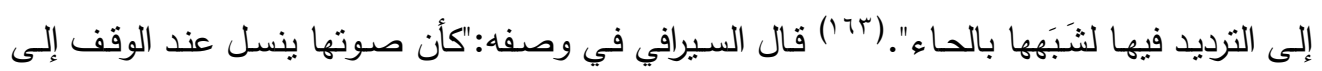

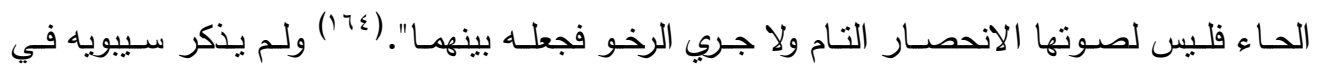

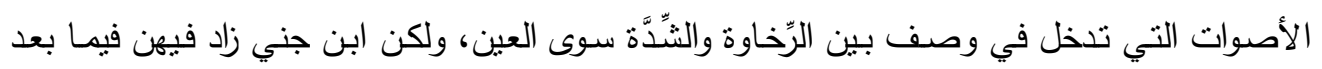

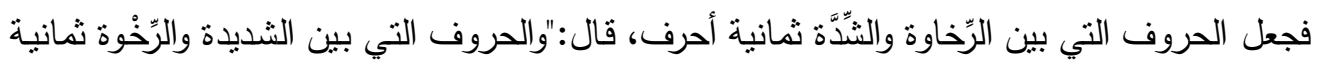

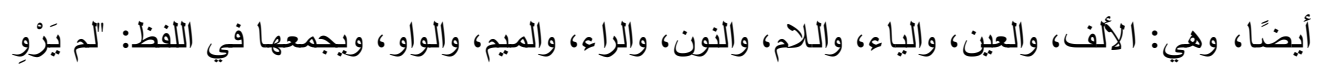

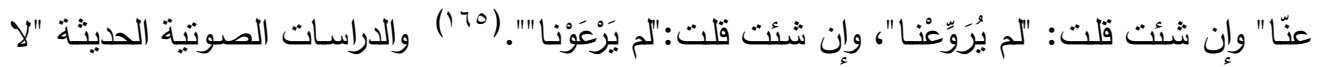

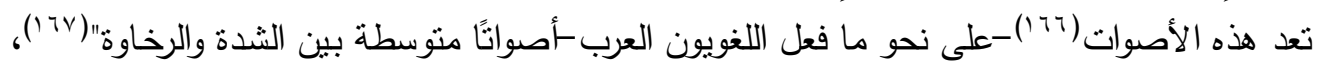

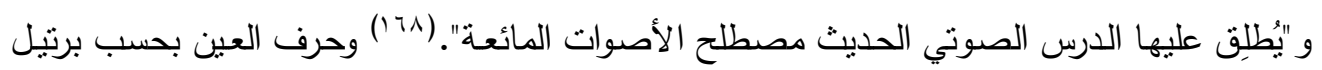

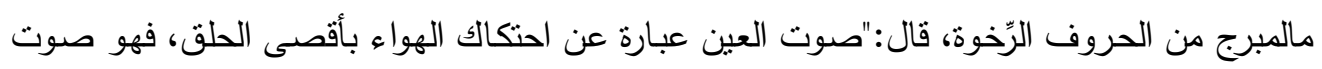
رخو ". (179) ولا نجد في كتاب العين مصطلح ما بين الرّّخو والثنديد.

\section{צ-الانحراف:}

قال سييويه في توضيح الحرف المُنحَرِف:"ومنها المُنْحَرِف وهو حرفتُ شديد جرى فيه الصوت

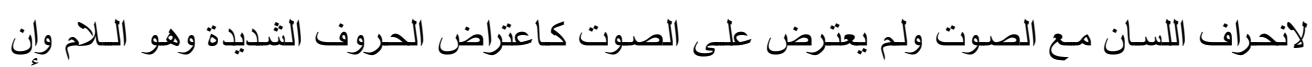

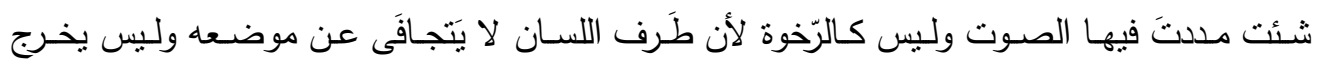

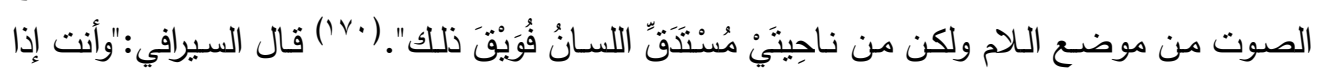




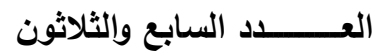

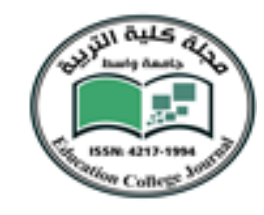

الجزء الثالث/ تشرين الثاني / 19

جامعة واسط

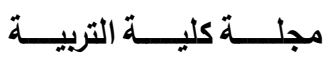

تأملتَ الذي قاله سيبويه وجدتَهَ كما قال: ولو سَدَنْتَ جَانبِيَ موضـع اللام لانحصر الصوت ولم يجرِ البته".( البال) قال محمد جواد النوري متحدثًا عن سبب وصف اللام بالانحراف:"ويعود السبب في تسمية

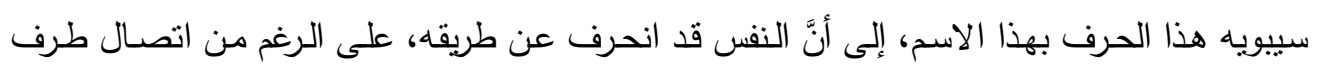

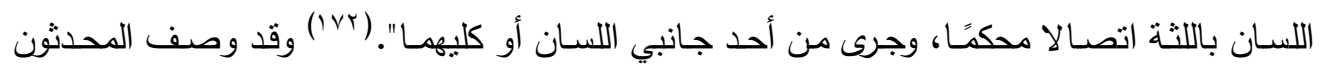
اللام بالجانبيّة في مقابل وصف سيبويه لها بالانحراف وهو اختلاف في المصطلح ليس أكثر ، قال محمد جـواد النـوري:"وإذا كـان المحدثون مـن اللغويين يطلقـون مصـطلح جـانبي Lateral على هـــا الصوت، فإن سيبويه لم يجانبه التوفيق في تسميته التي أوردها لهذا الصوت، حيث كان منطلقه في هذه التسمية هو ما يطرأ على نيار الهواء المتدفق من انحراف في الاتجاه والقصد. أما المحدثون وهم على صسواب في تسميتهم أيضًا-فقد كان منطلقهم، في تسمية هذا الصسوت بالجانبي، هو الموضـع

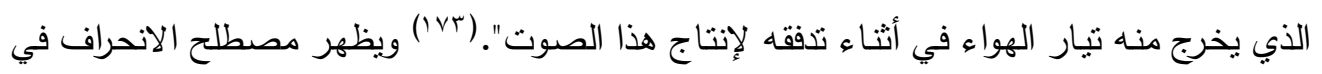
كتاب العين، إلا أن صـاحبه قد وصف النون بهذه الصفة خـلاف سيبويه، قـال صساحب العين:"ولم

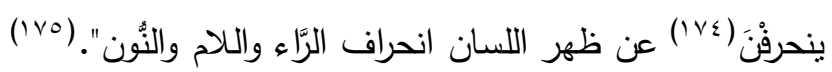

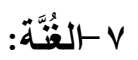

قال سيبويه في الغُنَّة وحرفَيَها:"ومنها حرف شديد يجري معه الصوت لأن ذلك الصوت غُنَّةٌُ من

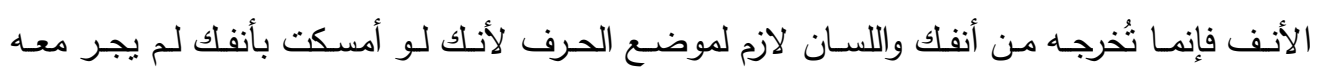

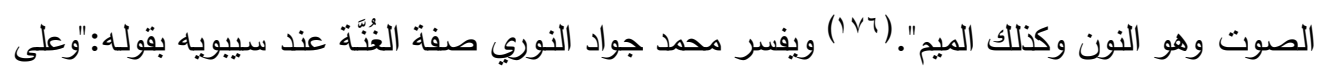
الرغم من دقة الثرح والتوضيح، الذي يقدمه المحدثون لمعنى الغُنَّة، فإننا نعتقد أن سييويه كان يقصد بها مجرد تميز صـوتي النـون والميم بالصفة الأنفيـة، التي يتسـمان بها، وتميزهما من غيرهمـا مـن

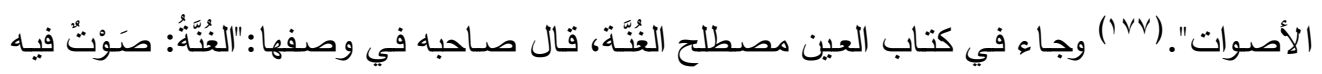

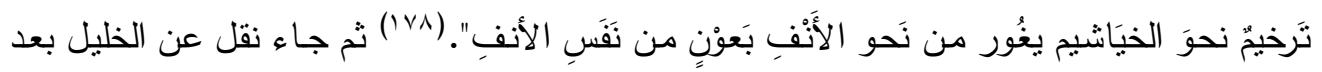

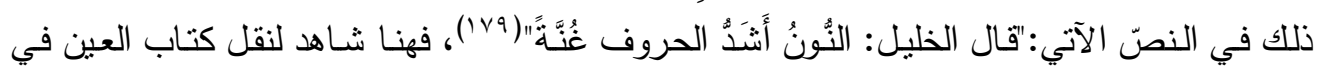
الجانب الصوتي عن الخليل وأنه ليس من تصنيفه. ^ التكرير:

خصّ سييويه الراء بصفة التكرير وفال في تعريف المكرَّر :"المكرَّرُ وهو حرف شديد يجري فيه

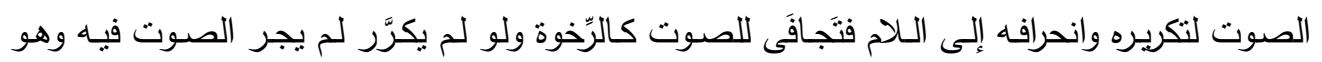




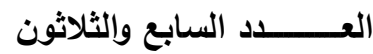

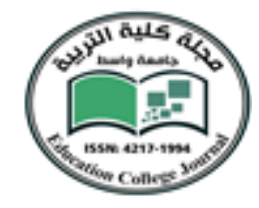

الجزء الثالث/ تشرين الثاني / 19

جامعة واسط مجلـــــة كليـــــة التربيــــــة

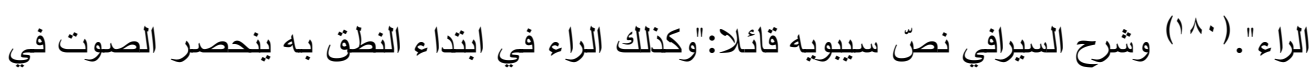

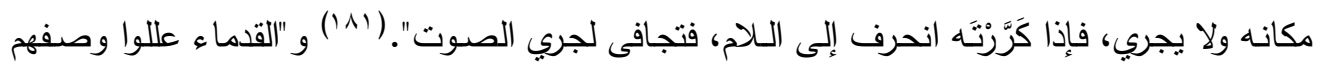
للراء بأنـه مكرر، لأن طرف اللسـان عند الوقف على الراء يتعثر، ومن أجل هذا أطلقوا مصطلح (المكرر أو التكرير) على الراء دون غيرها، إذ التكرير صفة ذاتيـة في الراء عندهم"(rA')، ويستعمل المحدثون المصطلح نفسه للراء(r^ا). ولم يستعمل صاحب العين هذه الصفة في كتابه.

: 9

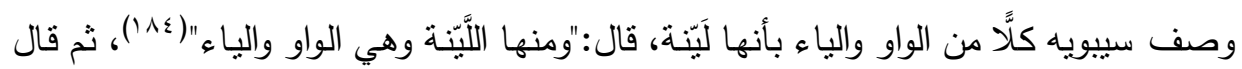

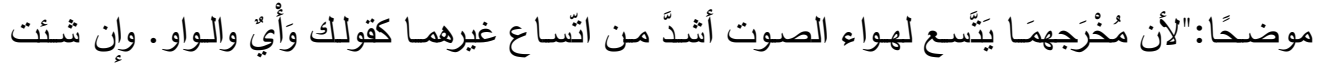

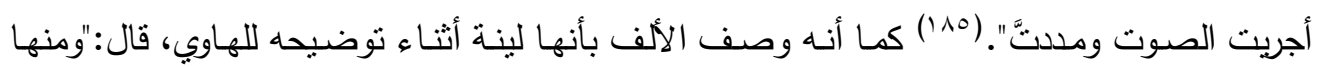

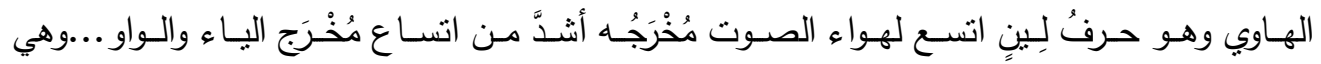
الألف".(זما) وينفي عبد العزيز الصيخ أن يكون سييويه قد عدّ الألف صونًا لينّا، يقول:"وعلى الرغم

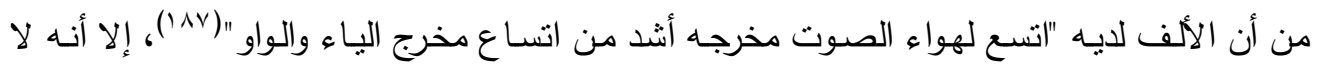
يدخله في فئة اللينة، وكأن اللين عند سييويه اتساع مخرج الصوت دون اتساع مخرج الألف، وأكثر من اتساع مخارج الأصوات الأخرى".(1^() ولكن ما ذكره عبد العزبز الصيغ ينتقي بما جاء في نصن سيبويه أعلاه الذي عدّ فيه الألف صونًا ليّنًا، ويمكن تأويل عدم ضمّ سيبويه الألف إلى الواو والياء عند حديثه عن صفة اللين، بأن سييويه قد عدّ الألف ليّنة إذا مـا قُوبلت بـالحروف الصحاح فعندئذ تكون مع الواو والياء في منزلة واحدة يجمعها معهما اتساع المخرج، وتكون هاويـة إذا ما قُوبلت بالواو

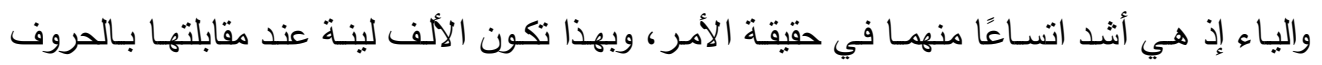
الصحاح، وهاويـة عند مقابلتها بـالواو واليـاء. ويختلف المحدثون عن سيبويه في تحديد الأصـوات اللينة، قال عبد العزيز الصيغ:"أما العلماء المحدثن فاللين عندهم هو المصوت، وأصسوات اللين هي الأصوات (المصوتة) أو الحركات، ويكون المخرج منسعًا بحيث يمر الهواء دون حوائل تعترضها....أما صوتا اللين بمفهوم القدماء وهما(الواو) و (الياء) فهما عندهم (أشباه أصوات اللين)". (199) وترد صفئة

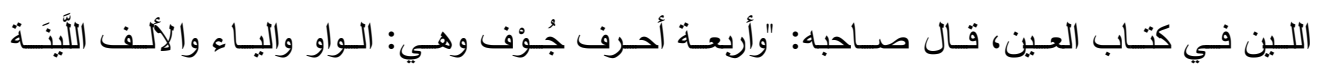
والهمزة". (·9) ونجده في موضع آخر يصرّح بأن الواو حرف لَيَّن، قال:"وإذا جاءت الحروف اللّيّنة في

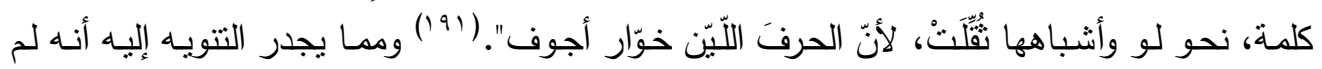

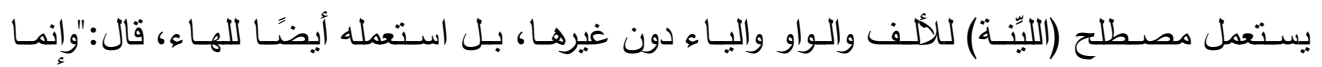




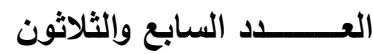

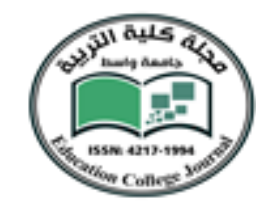

الجزء الثالث/ تشرين الثاني / 19

جامعة واسط

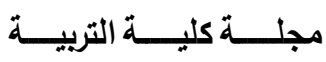

استحسنوا الهاء في هذا الضرب للينها وهشاشتها"( (9 ))، ليس هذا وحسب بل نجده يقول إن :"الهاء ألينُ

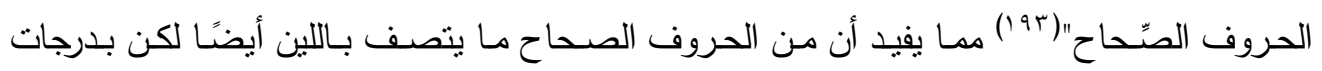
متفاوتة، في اختلاف عن ما جاء عند سييويه الذي حصر اللين في الألف والواو والياء. ولعل اللين الذي يريده صساحب العين غير اللين الذي يريده سيبويه. ومن الحديث عن لين الحروف في كتاب

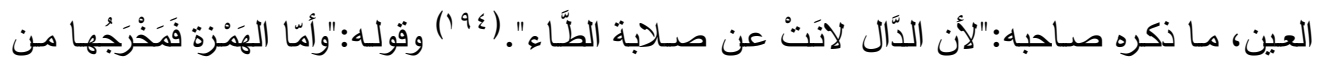

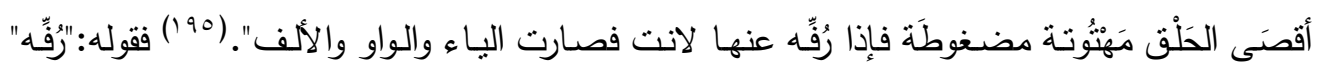

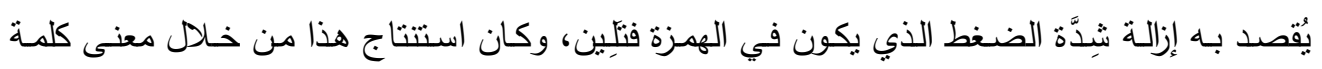

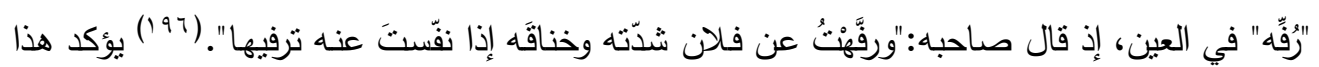

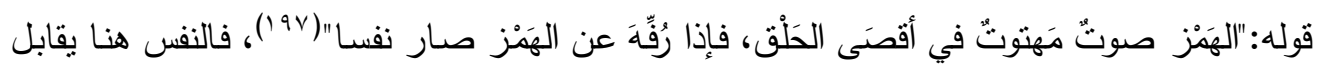
قوله:"لاتت" الذي ذكره في النصن آنفًا، من هذا نستتتج أن اللين عند صاحب العين يراد بـه ضعف في في الصوت ويتفاوت هذا بين حرف وآخر ، خلاف سيبويه الذي يريد به "إخراج الصوت بـلا احتباس أو هئ تضييق من نحو ما نلحظ في الأصوات الأخرى". (91')

• الكهاوي:

وصف سيبويه الألف بأنها هاويـة؛ لأن اتسـاع مخرجها لهواء الصـوت أشند مـن اتسـاعه للواو والياء، فالياء والواو بنـاءً على هذا نكون ليّنّة والألف تكون هاويـة فضـلا عن لينها كما ذكرنا سـابقًا،

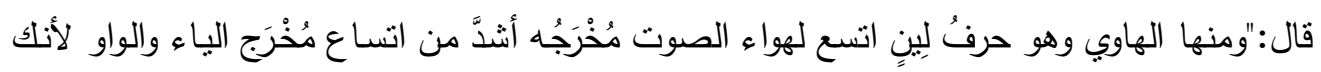

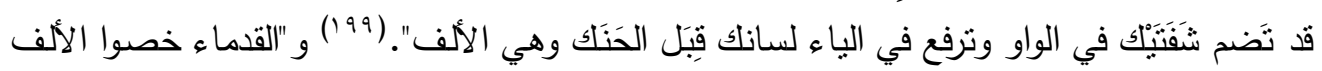

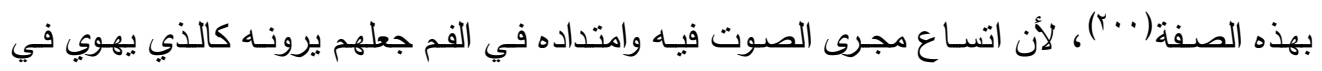

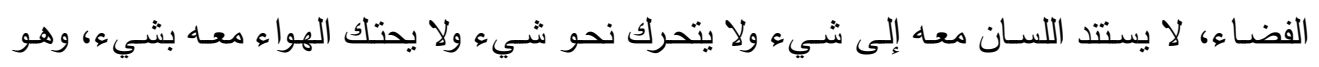
يختلف عن الواو والياء في هذا، فلذا خُصّ بهذا المصطلح دون غيره".( (r) وقد ورد مصطلح الهاوي

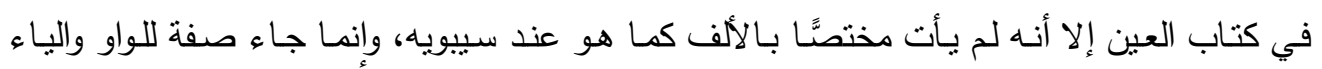

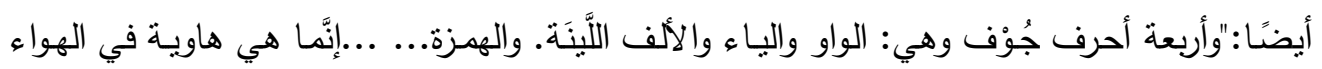

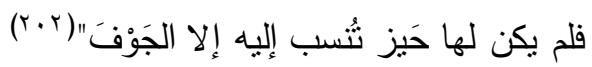




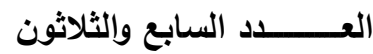

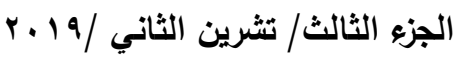

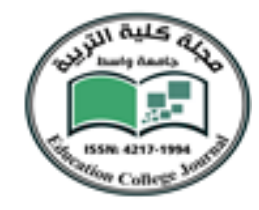

جامعة واسط

مجلـــــة كليـــــة التربيـــــة

11

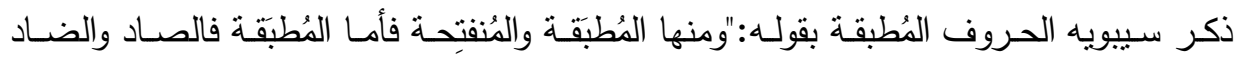

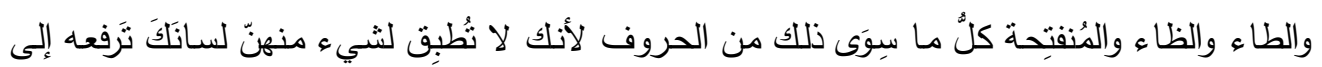

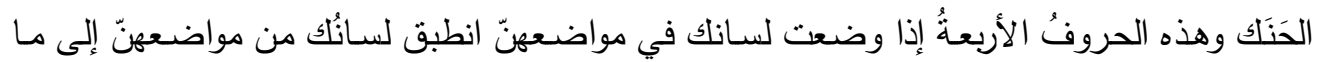

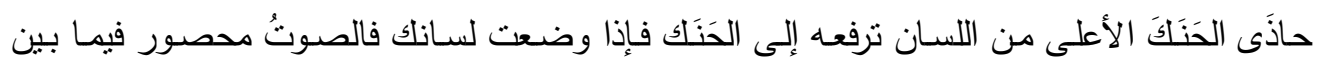
اللسان والحَنَك إلى موضـع الحروف".(r.r) ويشرح محمد جواد النوري نصّ سيبويه قائلا:"وهو يقصد بكلامه هذا، أن اللسان في حالة إنتاج هذه الأصوات، ينطبق على سقف الحنك الأعلى في موضعين اثثين لا في موضع واحد، كما هو الحال في الأصسوات غير المطبقة، مثل: الدال والزاي، حيث ينص

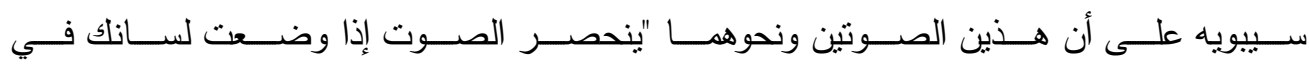

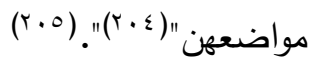

ثم يُحدّد هذين الموضعين، يقول:"وهذان الموضعان هما: ا-موضـع الإخـراج الأساسـي: Articulation : وهو المخرج الأسناني في حالة إنتاج صوت الظاء، والمخرج الأسناني اللثوي في حالة إنتاج أصوات الصاد، والضاد، والطاء. r-موضـع الإخـراج الثانوي:Secondary Articulation : ويقصـد بـه ارتفـاع مؤخرة اللسـان تجـاه

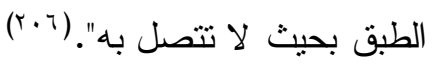

وقال عبد العزيز الصيغ معرّفًا الإطباق:"هو أن يتخذ اللسان عند النطق بالصوت شكلا مقعرًا منطبقًا

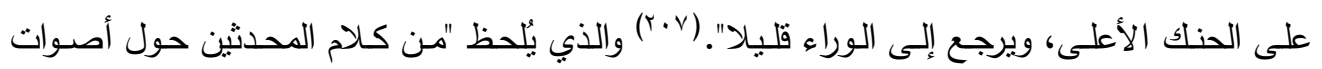
الإطباق. أن اللسان عند النطق بها يتقعر وسطه، وهذه الحالة لم يذكرها القدماء بل اكتقوا بالإشـارة

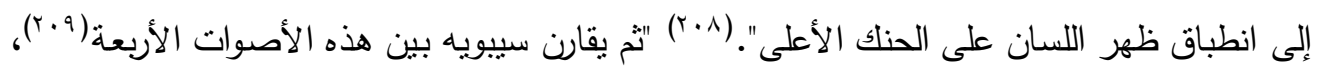

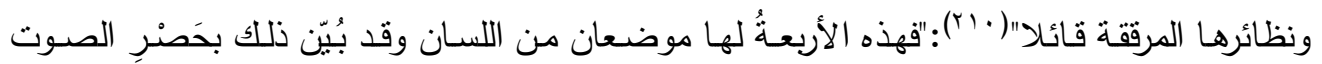

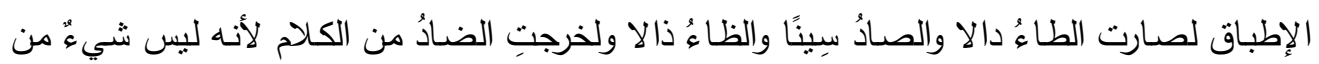

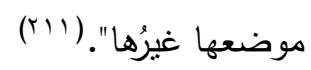

وقول سيبويه: "لولا الإطباق لصـارت الطاءُ دالا والصـادُ سِينًا والظـاءُ ذالا ولخرجت الضـادُ من الكـلام

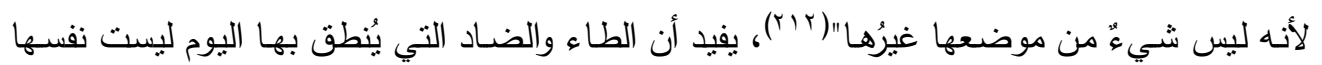
التي وصفها سيبويه، فالطاء التي أرادها سيبويه هي الضاد التي يُنطق بها الآن في مصر ، أمسا الضـاد 
التي أرادها سييويه فلا وجود لها اليوم في النطق الحديث، وناقش غانم قدُوري هذا النصّ قائلا: "فهذا

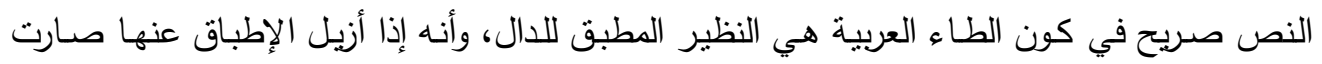

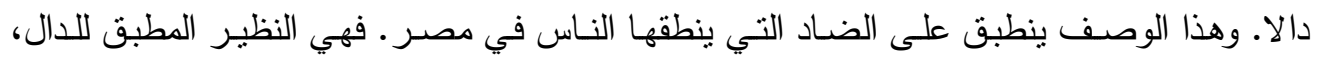

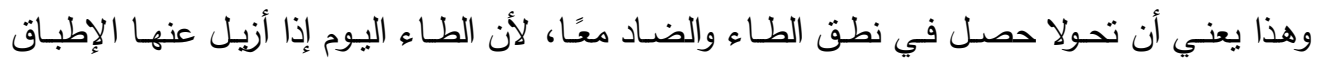

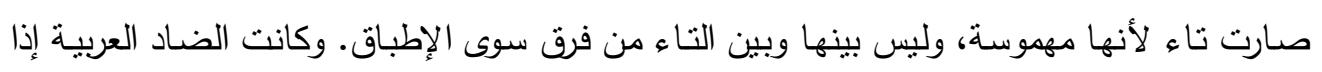

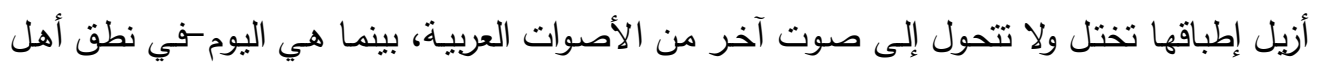

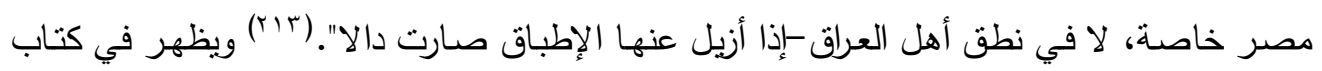

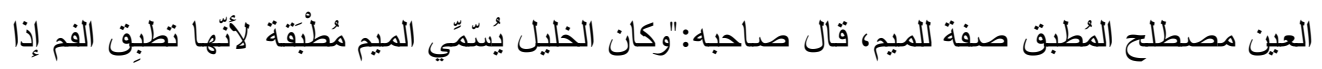

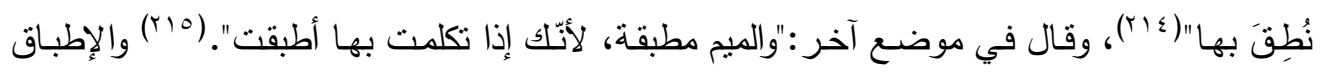

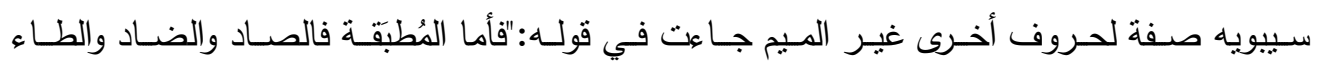

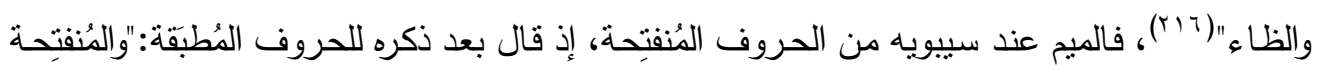

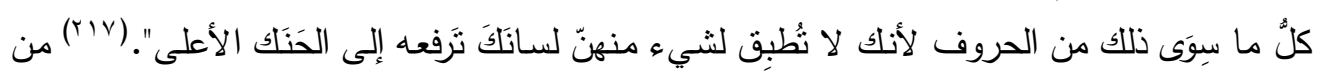

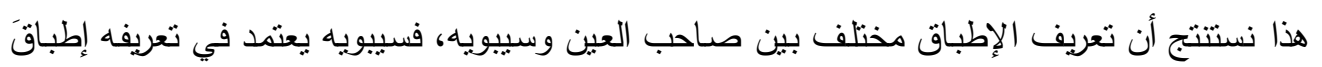

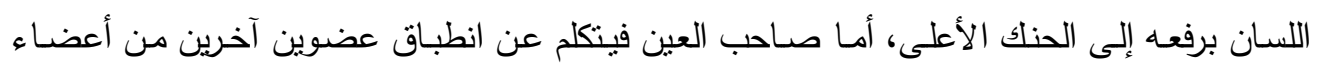

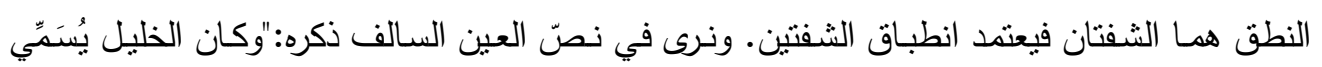
الميم مطبقة" ما يشير صراحة إلى أن صاحب العين ليس الخليل.

\section{r ا بالفتاح:}

الحروف المنفتحة عند سييويه هي جميع الحروف إلا الحروف المُطبقة الـذكورة في المسـألة

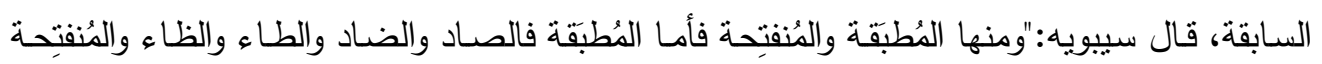

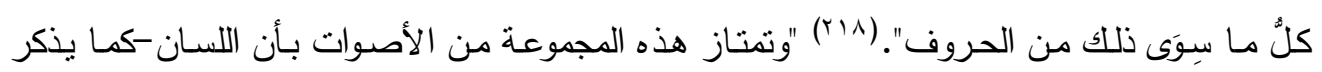

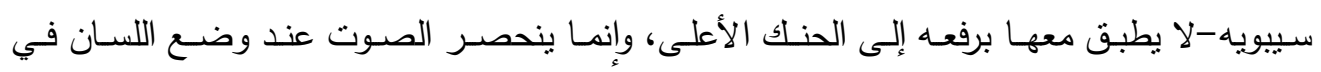

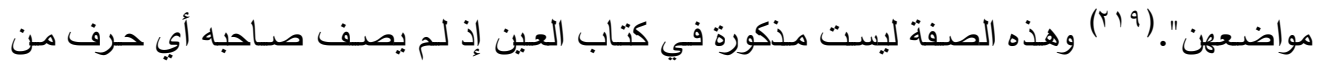
الحروف بهذه الصفة. 
العـــــــــد السـابع والثلاثون

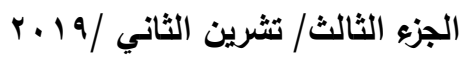

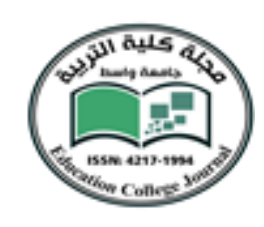

جامعة واسط

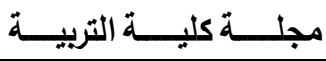

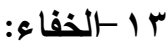

وصـف الخليـل الهـاء بأنها خفيّة، ونقل سـيبويه عنـه هـا في معرض حديثهـه عن فتح آخر

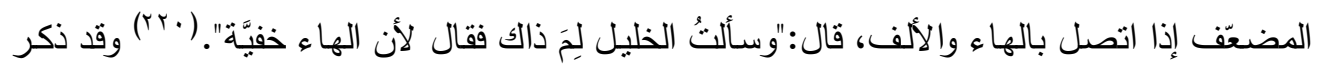

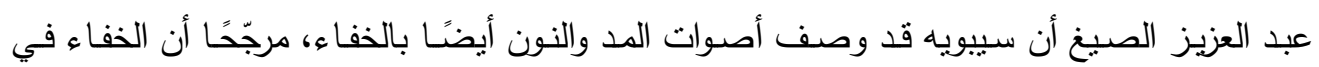

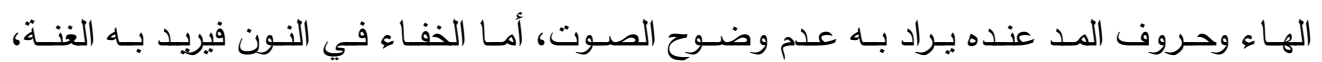
قال:"مصطلح الخفاء من مصطلحات سيبويه، وصف بـه أصسوانًا أربعة، وهي الهاء وأصسوات المد، وهـاء

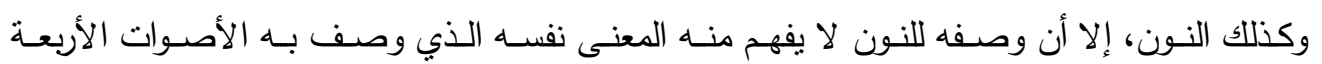
الأخرى، وإنما يقصد بها الغنّة، أمسا الخفاء في بقية الأصسوات فـالأرجح أنه يقصد بـه عدم وضسوح الصوت لاتساع المخرج".( (Yr) ولم يصف صاحب العين الهاء بصفة الخفاء وإنما وصفها بالهشاشـة كما سيأتي. ثناتيًا: صفات الأصوات في كتاب العين: جاءت في كتاب العين مجموعة من الصفات لم ترد في كتاب سيبويه، وتتمنل في:

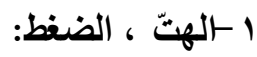

استعمل صاحب العين وصف مهتوتة ومضغوطة للههزة ويريد بالهتّ العصر ، قال:"وأمّا الهَهْزة

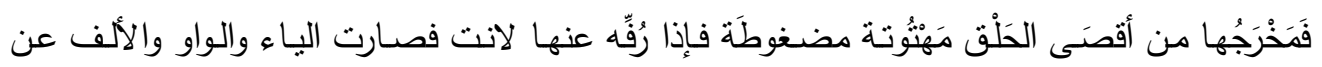

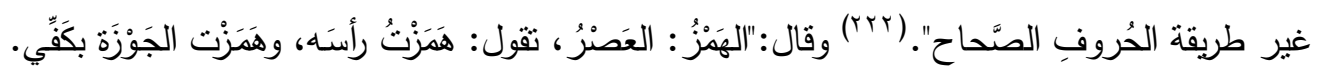

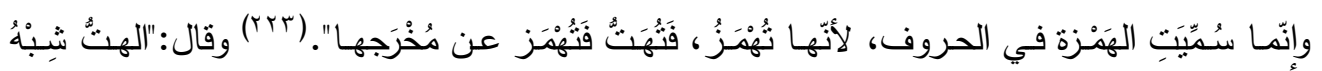

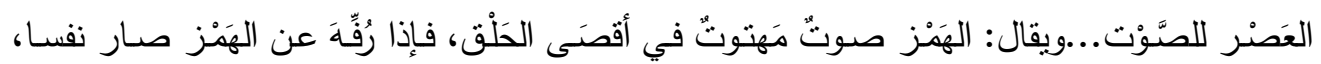

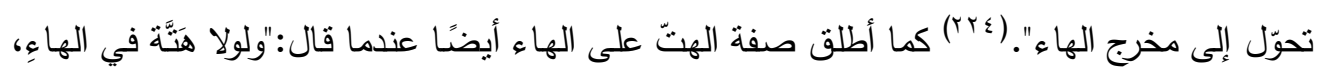

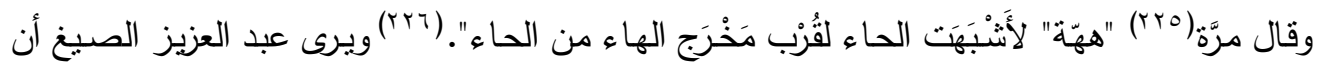
صـاحب العين عندما وصف الهاء بالهت فإنما يريد صـوت الهاء، قال :"أمـا وصفه للهاء فقد جـاء بمعنى صوت الهاء". (rrv) 
العـــــــــد السـابع والثلاثون

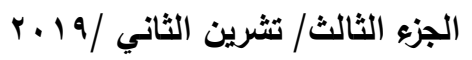

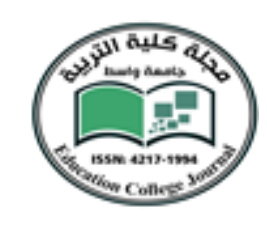

جامعة واسط

مجلـــــة كليـــــة التربيـــــة

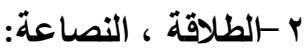

جعل صساحب كتاب العين الطلاقة والنصاعة صفتين لكلّ من القاف والعين، قال:"ولكن العين والقاف لا تدخلان في بناء إلا حَسَّنَّاه، لأنهما أطلق الحروف وأضخمها جَرْسا فإذا اجتمعا أو أحدهما

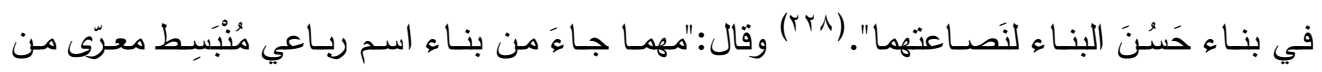

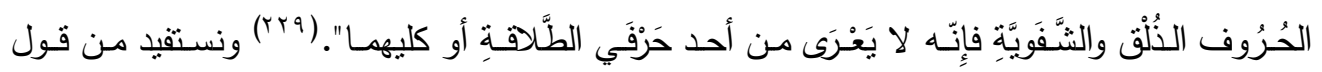
صاحب العين"لأنهما أطلق الحروف" أن هناك حروفًا أخرى غير القاف والعين تتصف بصفة الطفلافة الطفة

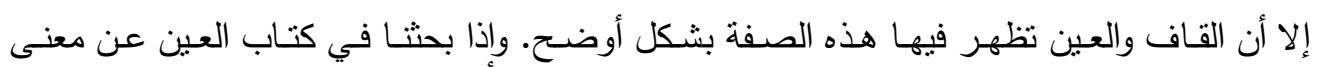

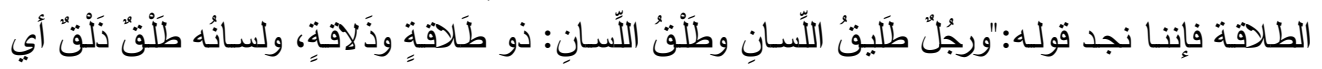

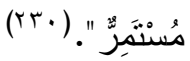

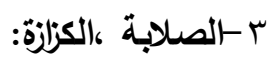

الصـلابة والكزازة عند صـاحب العين صفتان للطاء، قال:"لأن اللَّال لانَتن عن صـلابة الطَّاء

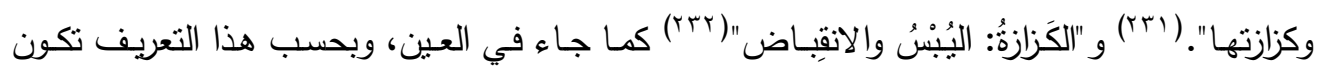

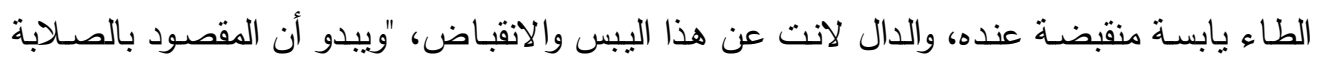

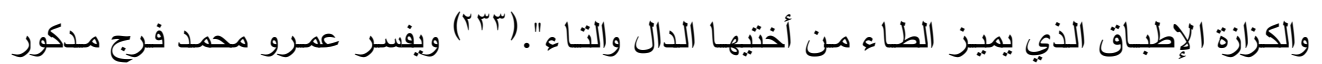
الكزازة قائلا:"ووصف الخليل(عrr) للطاء بالكزازة أبي الثَّدة في مقابل لين الدال، ربما جـاء من تفخيم الطاء في مقابل نرقيق الدال". (roor)

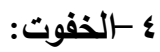

وصف صـاحب العين التاء بـالخفوت في معرض حديثه عن الدال، قال:"لأن الدَّال لاتَتْْ عن صـلابة الطَّاء وكزازتها وارتَفعت عن خُفُوت التّاء". (Trr) وجاء معنى الخفوت في كتاب العين على أنه

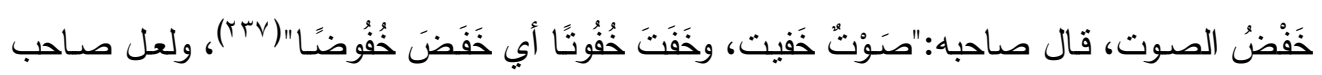
العين أراد أن صـوت التـاء صـوت مخفوض. قـال عمـرو محمد فـرج مـدكور في الخفوت:"ومفهوم الخفوت صفة سمعية، شعر بها الخليل، وسببها همس التاء مقابل جهر الدال؛ فالدال النظير المجهور للتاء، والطاء النظير المفخم للتاء، فكأن صفة الخفوت أثر سمعي لصفتي الههس والترقيق".(^r^) 
العــــــــد السـابع والثلاثون

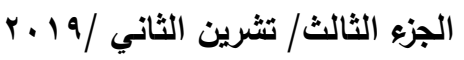

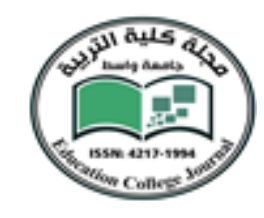

جامعة واسط

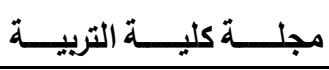

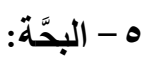

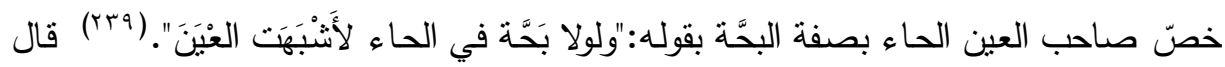

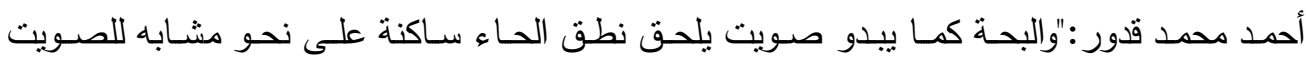

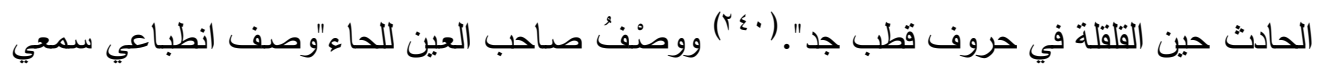

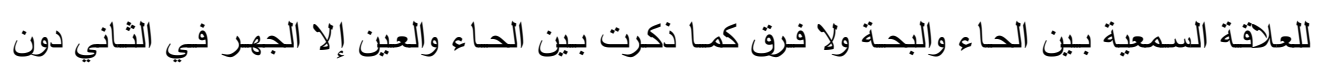

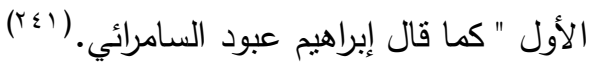

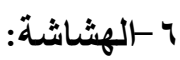

قـال صـاحب العين واصـفًا الهـاء بالهشاشـة:"وإنما استحسـوا الهاء في هذا الضـرب للينهـا

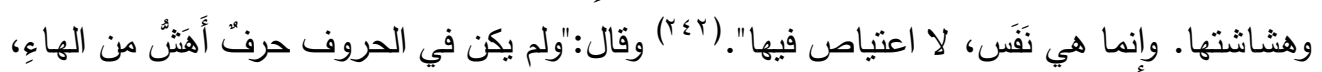

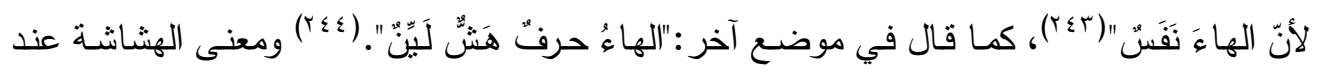

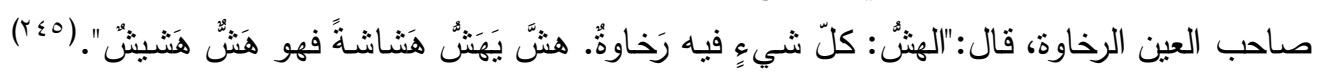

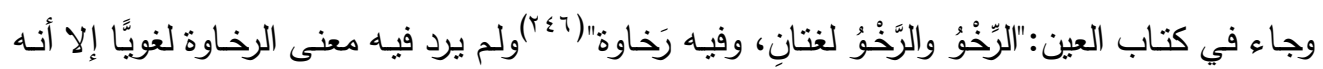

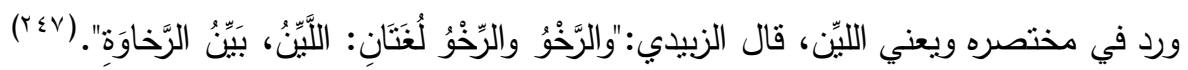

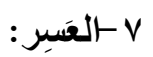

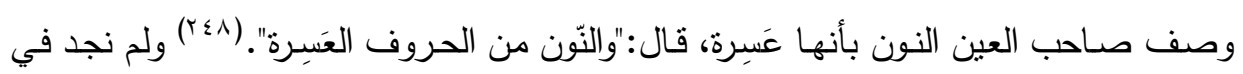

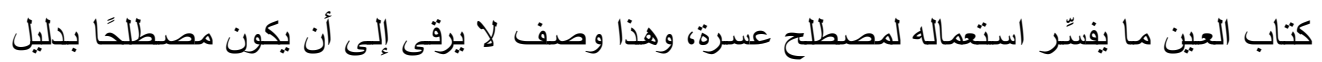
عدم استعماله مرة أخرى في كتاب العين. $\Lambda$

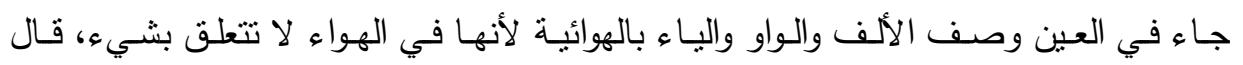

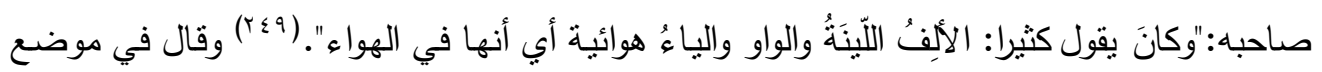

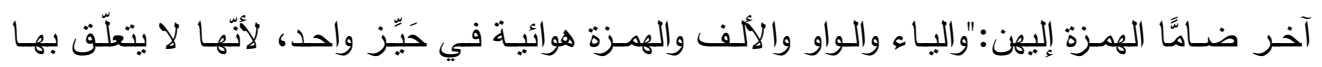

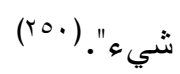

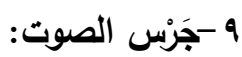

العين والقاف عند صاحب العين تتصفان بأنهما (الأضخم جَرْسًا)، قال:"ولكن العين والقاف لا

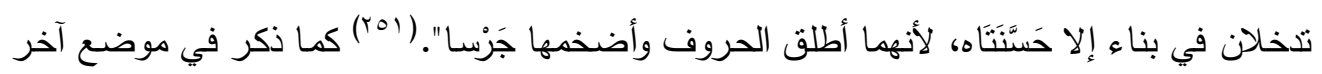




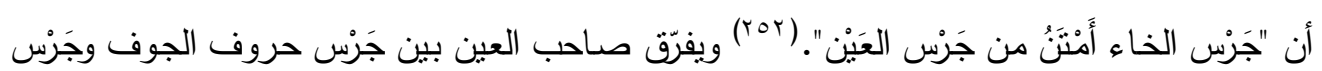

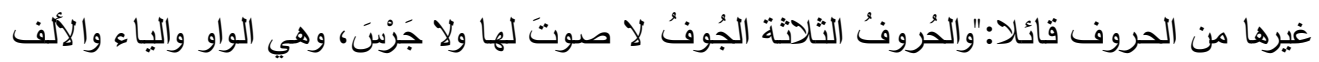

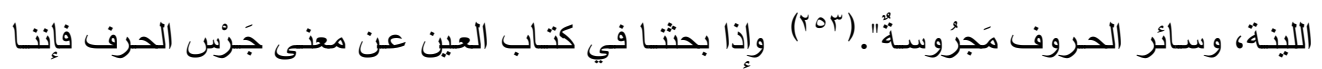

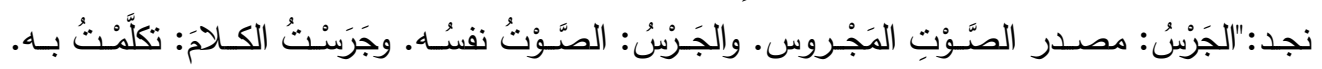

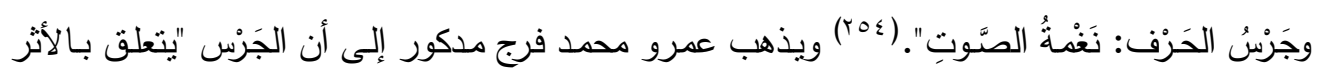

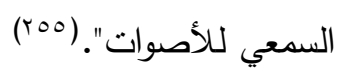

الخاتمة

تتاولتُ هذه الدراسة مخارج الأصوات وصفاتها في كتاب سيبويه موازنة بما جاء في العين؛ للكثف

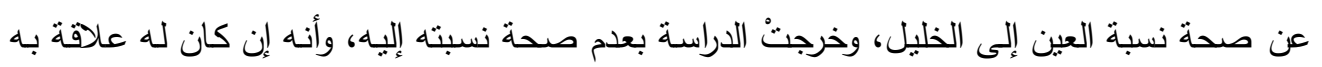

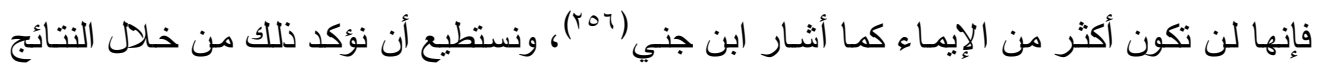

الآتية:

1 - أن مخارج الأصوات في كتاب العين إمـا أن ترد مخالفة لها جاء عند سييويه، وتتمثلّ في:

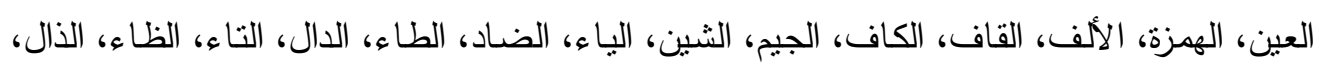
الثاء، الواو.

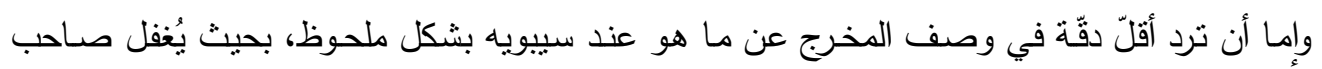

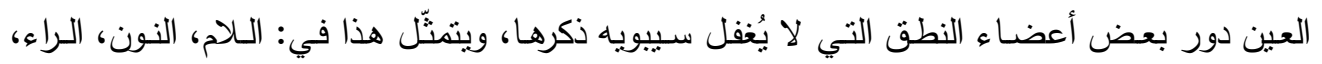

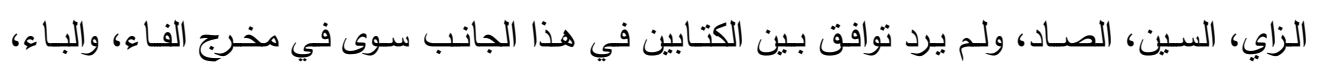

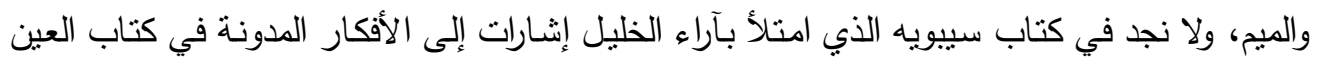
فيما يختصنّ بمخارج الأصوات.

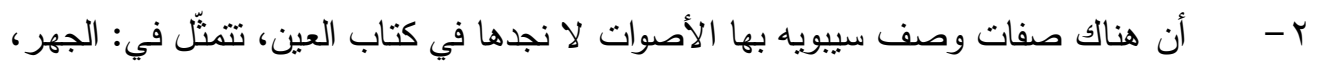

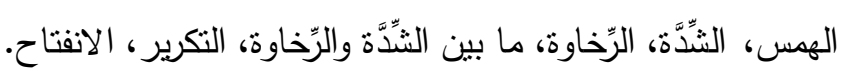

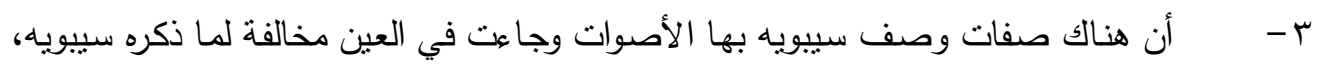
وهي كما بأني: 


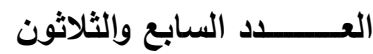

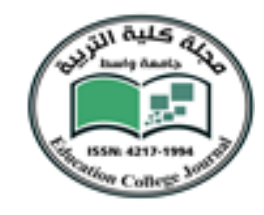

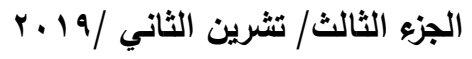

جامعة واسط

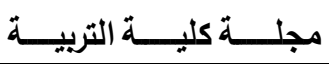

الاختلاف بين كتاب سيبويه وكتاب العين في تعريف الحرف الليّن، فالليّن عند سيبويه هو

ما اتسع مخرجه لهواء الصوت أشذّ من اتساع غيره، ومحصور في الواو والياء والألف، في حين هو في كتاب العين ضعفُ في الصوت وليس محصورًا في الواو والياء والألف بل يخرج إلى غيرها. الاختلاف بين كتاب سيبويه وكتاب العين في الهاوي، إذ أفرد سيبويه له الألف، في حين أن

الهاوي في كتاب العين صفة للواو والياء بجانب الألف.

الاختلاف بين كتاب سيبويه وكتاب العين في تعربف الحرف المُطبق، فالمُطبق عند سييويه

هو ما ينطبق لله اللسان برفعـه إلى الحنك الأعلى، وعند صـاحب العين هو مـا تتطبق لـه الشفتان،

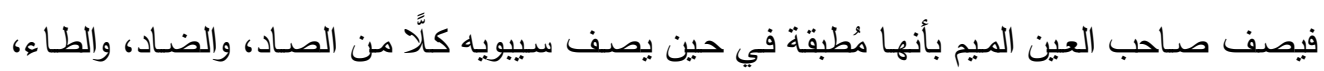
والظاء بالمُطبقة.

وصَفَ صاحب العين النون بالانحراف مخالفًا بهذا سيبويه الذي لم يصفها بهذه الصفة، ولم

يتفق الكتابان في جانب صفات الأصوات إلا في صفة الغنّة إذ كان تعريفها متشنابهًا. ويذخل بضمن هذه الاختلافات ما نقله سيبويه عن الخليل من وصف الهاء بالخفاء، إذ لم

توصَف في العين إلا بالهثاشة.

ع - ورود صفات للأصسوات في كتاب العين لا نجد لها صديً في كتاب سييويه، هي: الهتّ، الضغط، الطلاقة، النصـاعة، الصـلابة، الكزازة، الخفوت، البحَّة، الهشاشـة، العَبِر ، الهوائي،

$$
\text { جَرْس الصوت. }
$$

وقد خرج من هذه الدراسة نتائج أخرى لا تتعلق بأمر نسبة العين إلى الخليل، تتلخص في الآتي:

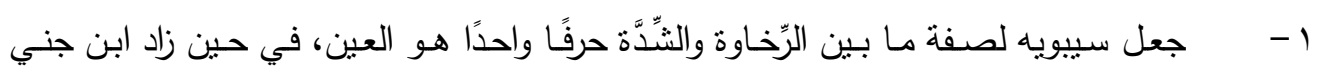
فجعل التي بين الرّخاوة والثَّدَّة ثمانية أحرف. r - عدم صحة مـا ذهب إليه كمـال بشر عندما افترض أن صـاحب العين قد أخطأ في تقدير مخرج القاف أو أخطأ في ثقدير مخرج الكاف، كما أن افتراضه أن صساحب العين لم يفطن إلى موضع اللهاة في الجهاز النطقي افتراض غير صحيح.

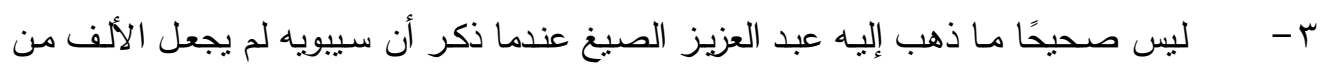
الأصوات اللينة بجانب الواو والياء.

ع - يرى صاحب العين أن هناك حروفًا أخرى غير القاف والعين تتصف بصفة الطلاقة، إلا أن القاف والعين تظهر فيهما هذه الصفة بشكل أوضح. 0- وصف صاحب العين التاء بالخفوت، وكان يريد بهذا أن صوتها صوت مخفوض. 
العــــــــد السـابع والثلاثون

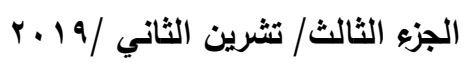

جامعة واسط مجلــــة كليـــة التربيـــة

7 - اختلف المحدثون مع سيبويه في مخرج الألف، في حين أن ما ذهبوا إليه يقارب مـا ذهب إليه صاحب العين في مخرجها.

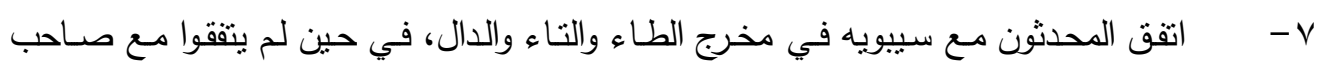
العين فيها.

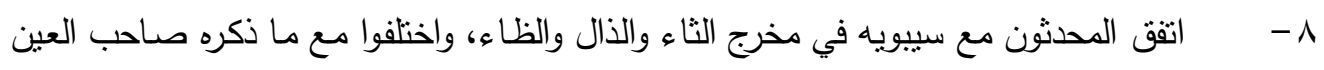

$$
\text { وفيها. }
$$

الهوامش - اش

(') أثنار السيوطي إلى فكرة الاختلاف بين مقلمة العين وكتاب سيبويه في كتابه المزهر في علوم اللغة وأنواعها

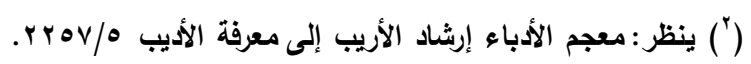

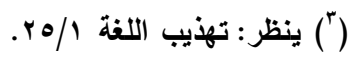

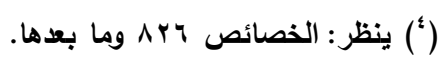

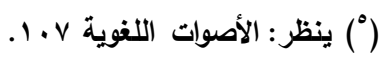

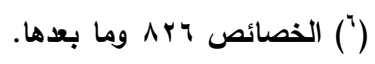

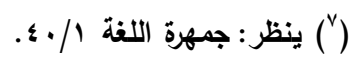

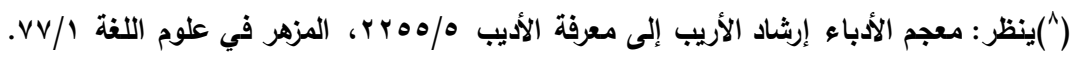

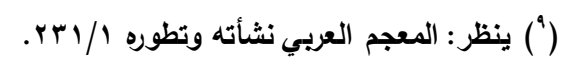

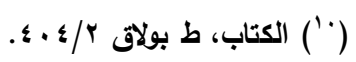

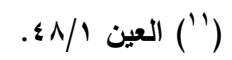

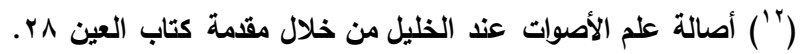

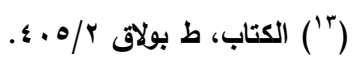

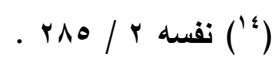

$$
\begin{aligned}
& \text { (") }
\end{aligned}
$$

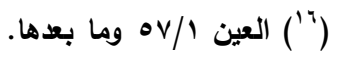

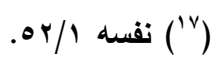

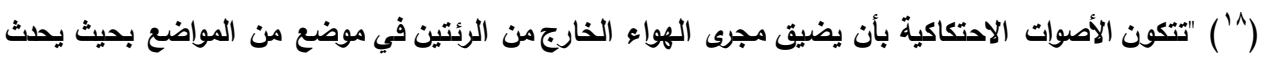

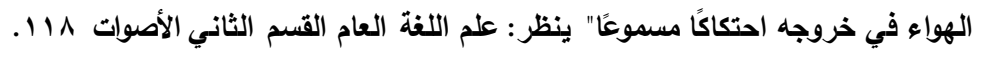


العـــــــد السـابع والثلاثون

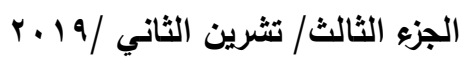

جامعة واسط

مجلـــــة كليـــــة التربيـــــة

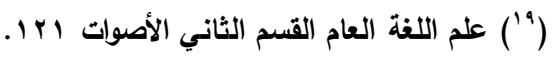

(r.)

(")

(T)

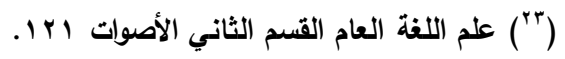

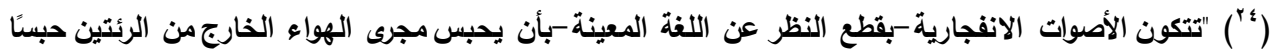

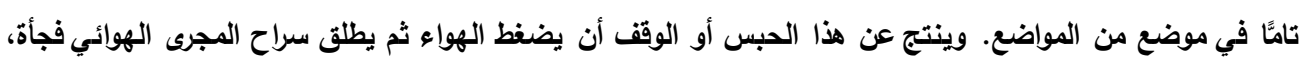

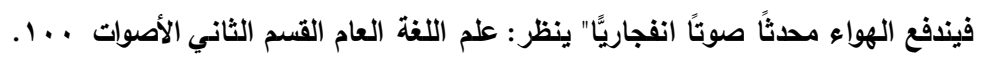

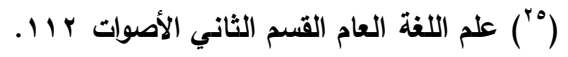

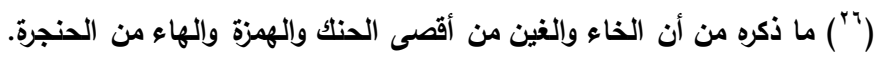

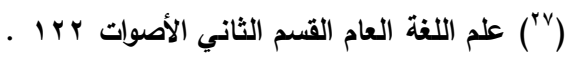

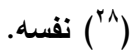

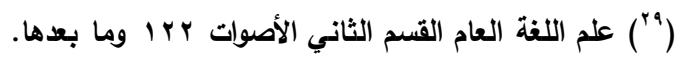

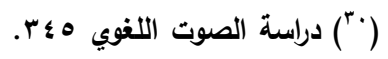

. نفسل

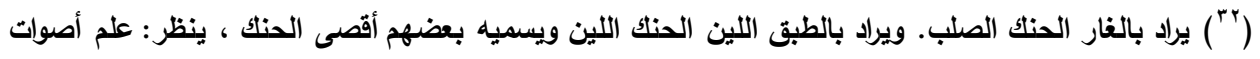

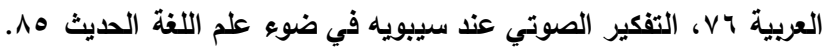

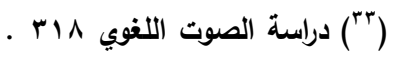

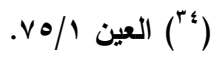

(") (") ) يريد صاحب العين ومن تبعه.

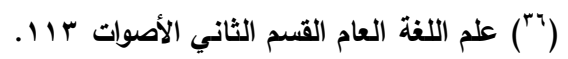

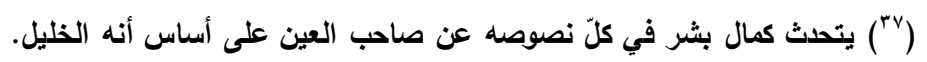

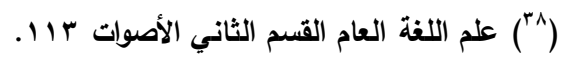

نفسه (")

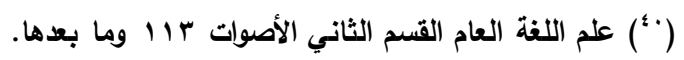

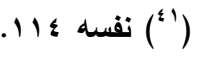

$$
\begin{aligned}
& \text { ( ) ( }
\end{aligned}
$$

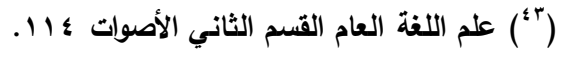

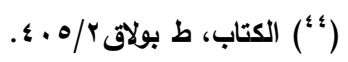

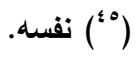

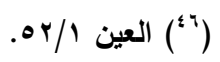


العـــــــد السـابع والثلاثون

الجزء الثالث/ تشرين الثاني / 19
جامعة واسط مجلـــــة كليـــــة التربيـــــة

$$
\begin{aligned}
& \text { (4v) }
\end{aligned}
$$

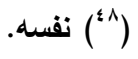

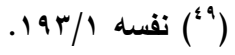

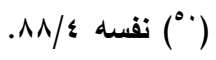

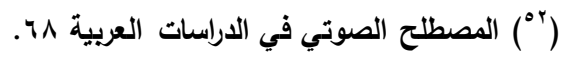

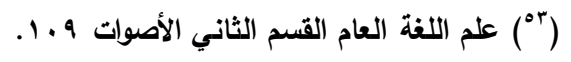

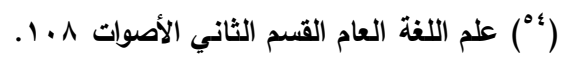

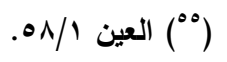

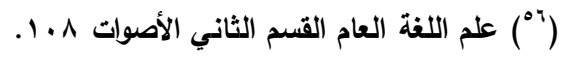

نفسه.

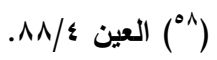

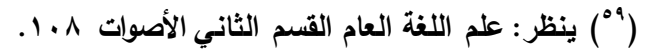

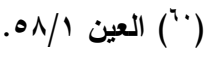

$$
\begin{aligned}
& \text { (") }
\end{aligned}
$$

(r) ينظر : التشكيل الصوتي في اللغة العربية فونولوجيا العربية 9 ؛ .

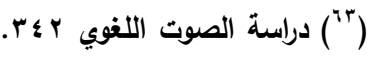

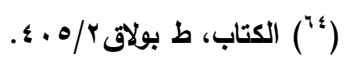

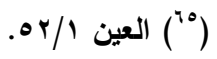$$
\text { (17) }
$$

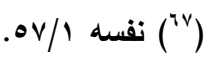$$
\text { . نفسن ("in) }
$$

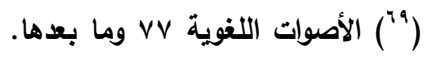

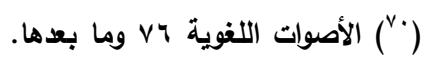

$$
\text { .vv نفسه ( (v) }
$$

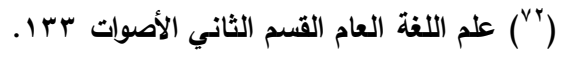

$$
\text { (لفسه (N") }
$$

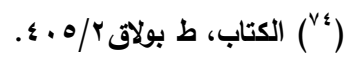

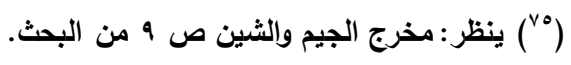

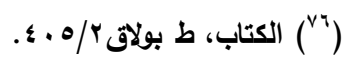

نفسه. (Nv) 
العـــــــد السـابع والثلاثون

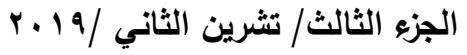

جامعة واسط

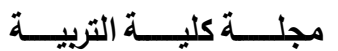

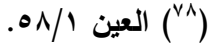

$$
\begin{aligned}
& \text { (لفسه. (va ) }
\end{aligned}
$$

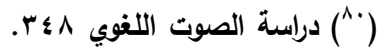

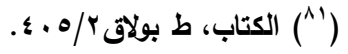

(لف

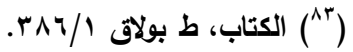

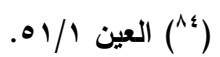

.01/1 نفسل

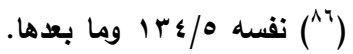

ن ن $\left({ }^{\wedge V}\right)$

نفسه $14 / \mathrm{r}\left({ }^{\wedge \wedge}\right)$

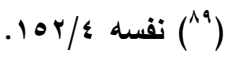

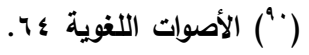

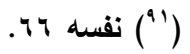

(")

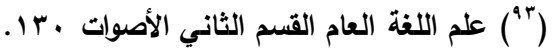

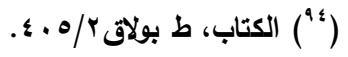

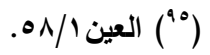

(17/ نفسه

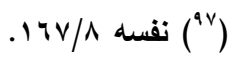

.01/1 نفسه

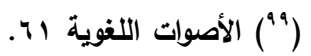

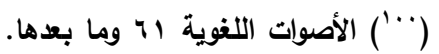

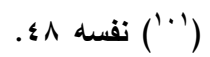

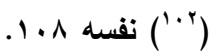

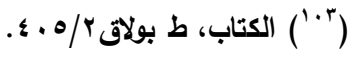

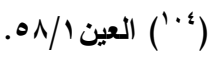

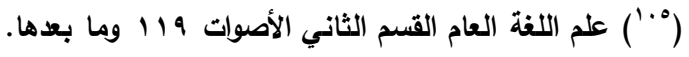

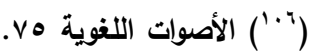

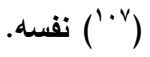

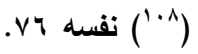


العـــــــد السـابع والثلاثون

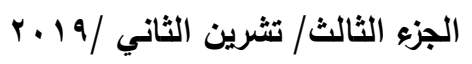

جامعة واسط مجلـــــة كليـــــة التربيـــــة

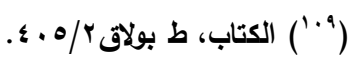

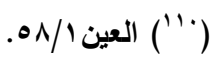

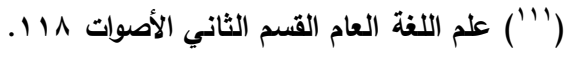

$$
\text { .119 (119) }
$$$$
\text { . (") }
$$

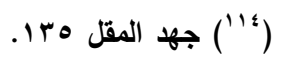

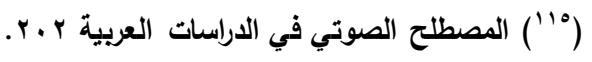

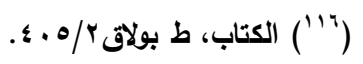$$
\text { (lly }
$$

(1/1)

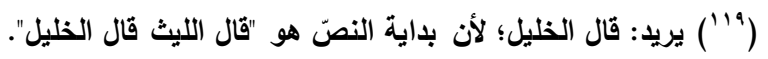

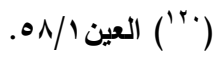

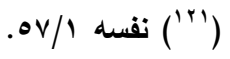

$$
\begin{aligned}
& \text { (Tr) }
\end{aligned}
$$

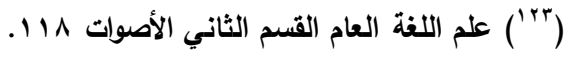

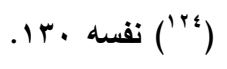

.1.1 فن (170)

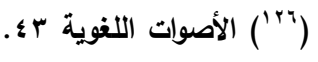

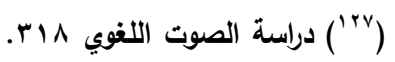

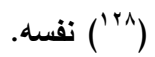

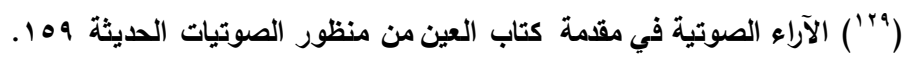

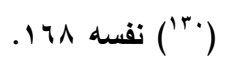

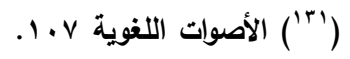

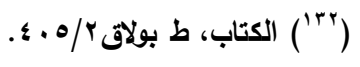
(الأمبو

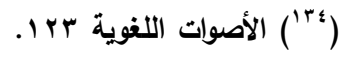

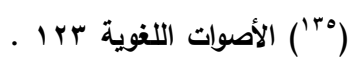

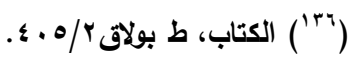

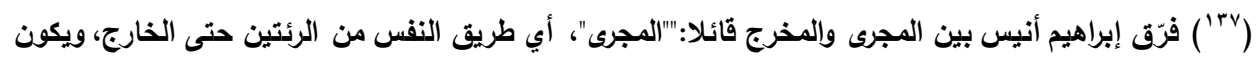

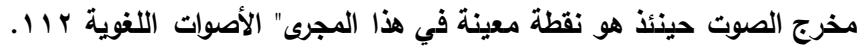

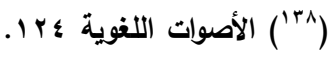


العــــــــد السـابع والثلاثون

جامعة واسط

الجزء الثالث/ تشرين الثاني / 19

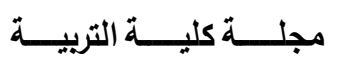

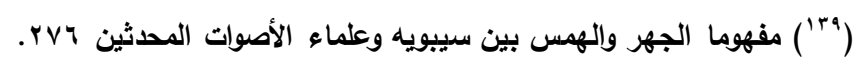

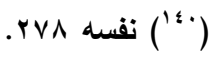

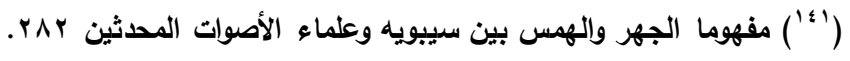

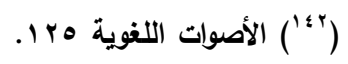

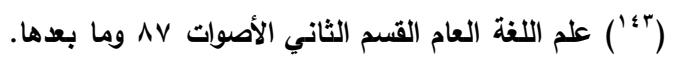

(4 ؛ ') يريد إبراهيم أنيس بأصوات اللين هنا ما يسمى بالحركات القصيرة والحركات الطويلة، ينظر : الأصوات اللفوية

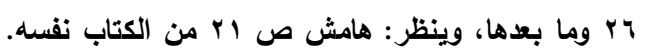

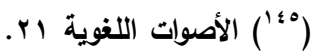

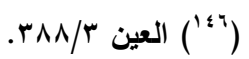

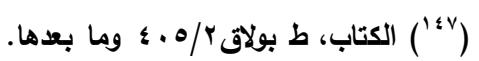

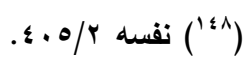

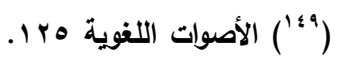

. Y

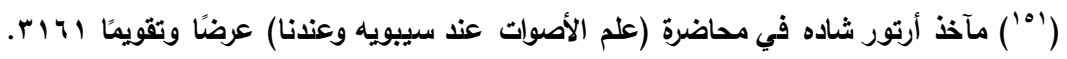

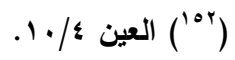

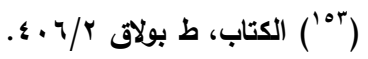

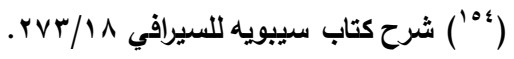

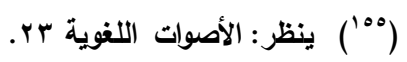

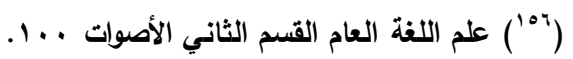

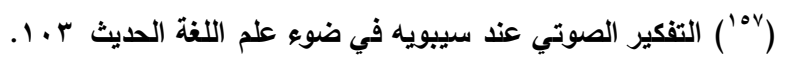

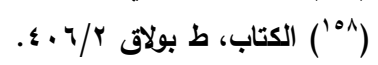

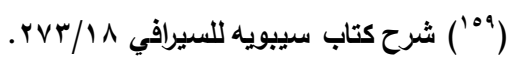

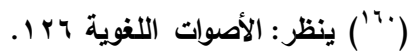

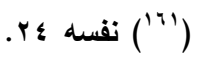

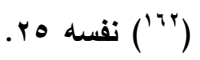

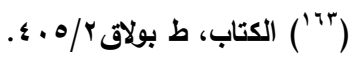

(

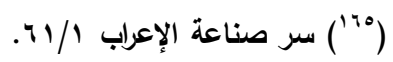

("7rا') الأصوات المجموعة في قوله: "لم يَزْوِ عنّا".

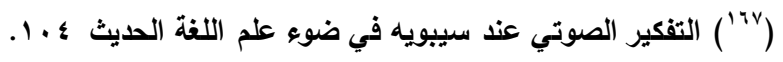
(174) 
العــــــــد السـابع والثلاثون

الجزء الثالث/ تشرين الثاني / 19

جامعة واسط

مجلـــــة كليـــــة التربيـــــة

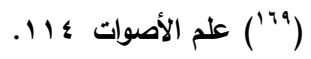

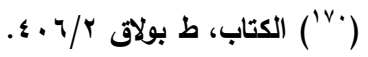

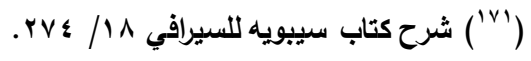

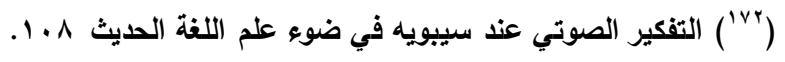
نفسه.

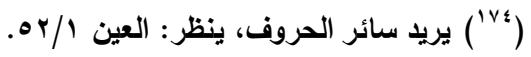

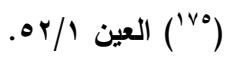

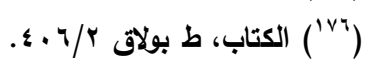

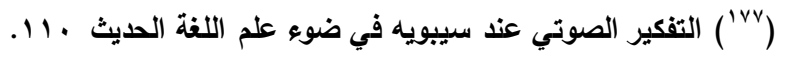

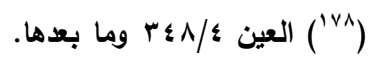

نفسه. (1va

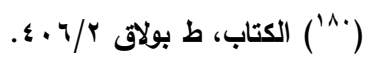

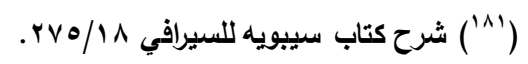

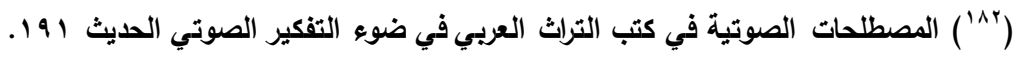

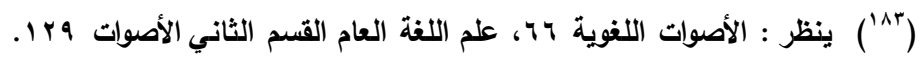

( الكتاب، ط بولاق r/

(1/0)

نفسه. (107)

(linv $\left(^{\text {inv }}\right.$

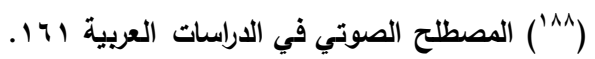

. نفسه \& (199)

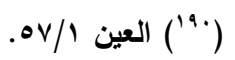

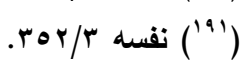

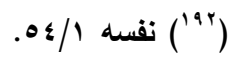

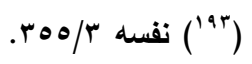

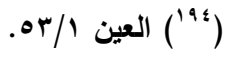

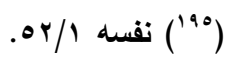

(ن)

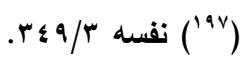

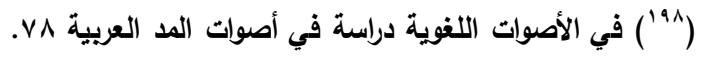

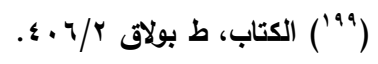


العــــــــد السـابع والثلاثون

الجزء الثالث/ تشرين الثاني / 19

جامعة واسط

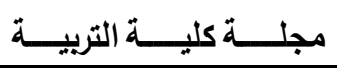

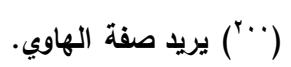

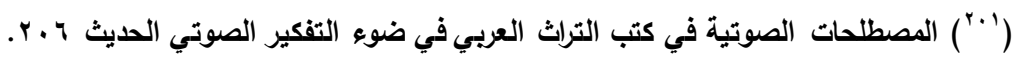

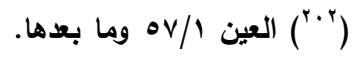

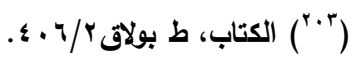

. (ب.s)

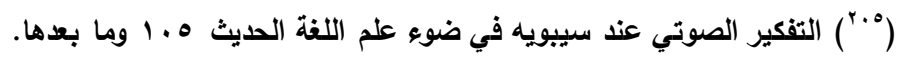

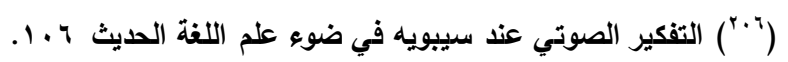

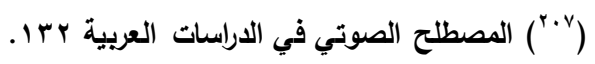

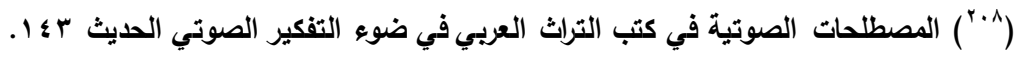

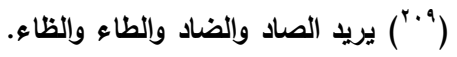

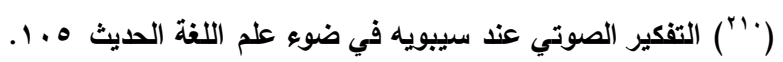

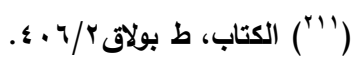

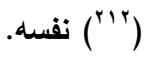

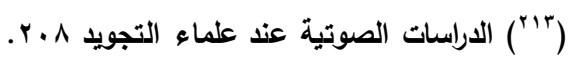

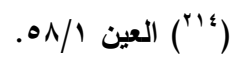

$$
\begin{aligned}
& \text { (Y) }
\end{aligned}
$$

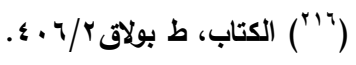

$$
\begin{aligned}
& \text { نفسه. }
\end{aligned}
$$

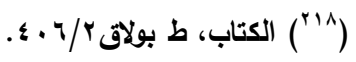

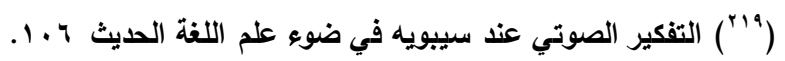

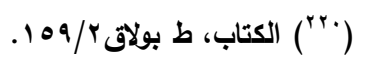

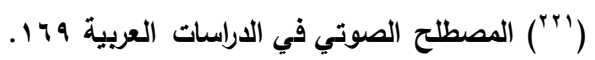

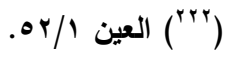

$$
\begin{aligned}
& \text { (V) } \\
& \text { ) (r) }
\end{aligned}
$$

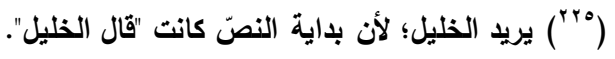

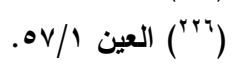

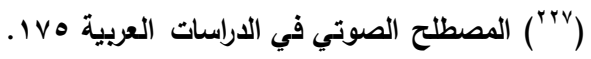

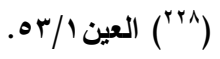

$$
\begin{aligned}
& \text { ( ) }
\end{aligned}
$$

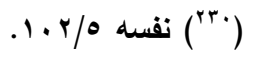


العــــــــد السـابع والثلاثون

جامعة واسط

الجزء الثالث/ تثرين الثاني / 19

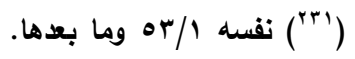

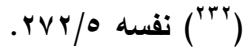

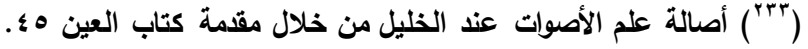

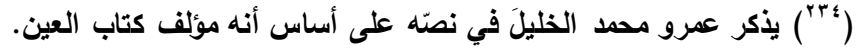

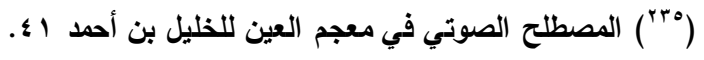

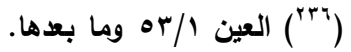

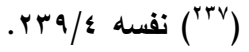

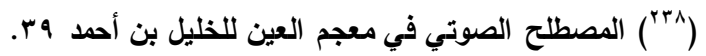

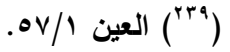

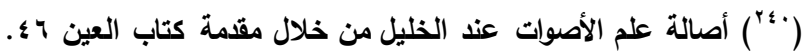

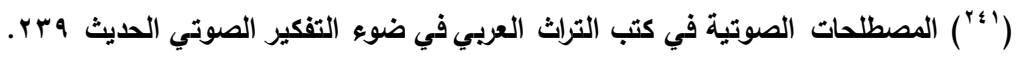

(العين (r)

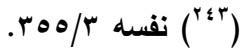

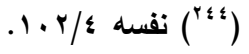

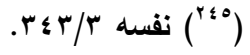

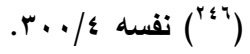

( )

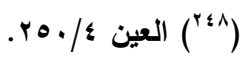

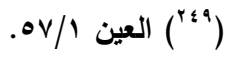

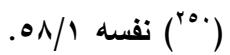

. نفسه

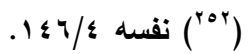

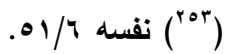

. نفسه

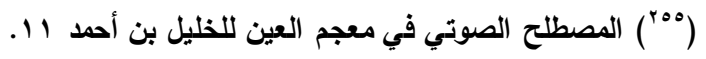

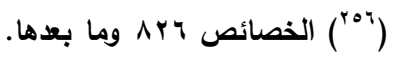


العـــــــــد السـابع والثلاثون

الجزء الثالث/ تشرين الثاني / 19

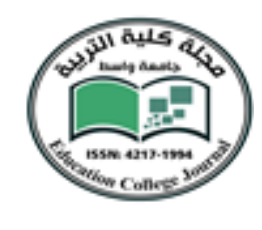

جامعة واسط

مجلـــــة كليـــــة التربيـــــة

\section{المصادر والمراجيع}

1 - أصالة علم الأصوات عند الظليل من خـلال مقدمة كتاب العين، د.أحمد محمد قدور، دار الفكر، دمشق، طץ،

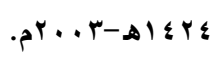

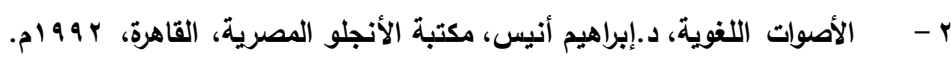

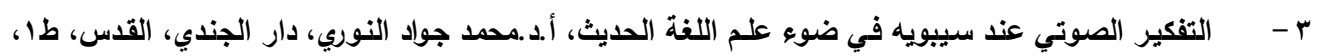

. 19

؛ - التثكيل الصوتي في اللغة العربية فونولوجيا العربية، د.سلمان حسن العاني، ترجمة: د.ياسر الملاح، النادي

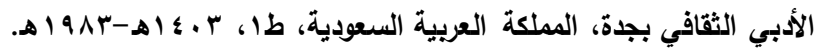

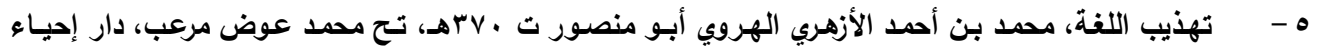

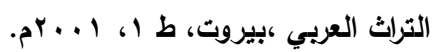

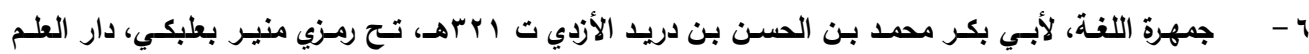

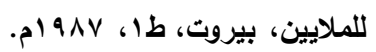

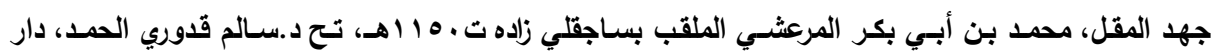

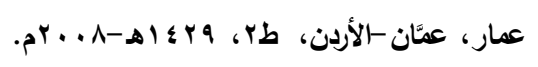

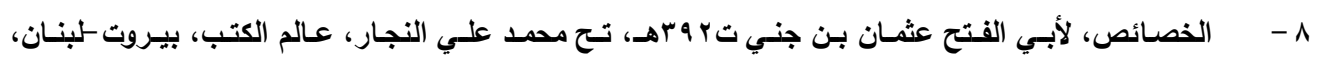

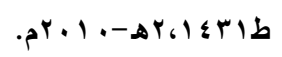

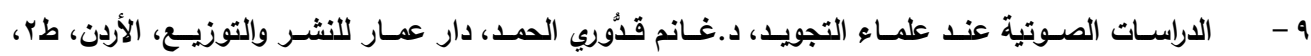

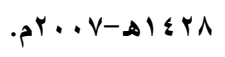

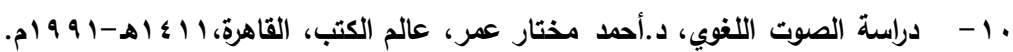

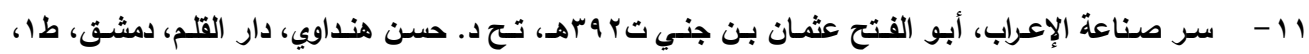

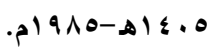

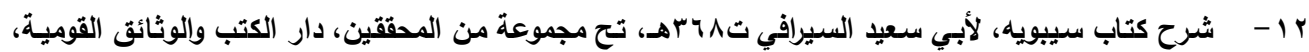

القاهزة.

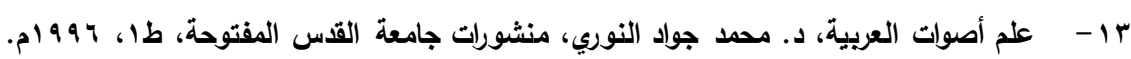

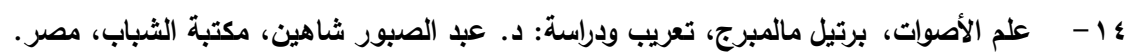

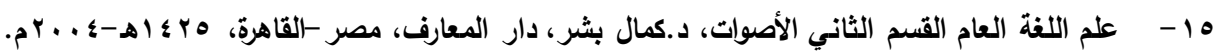

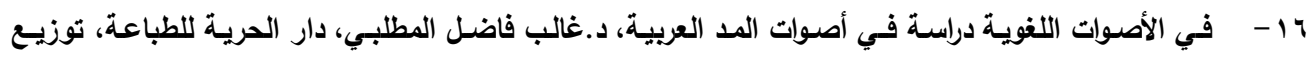

الدار الوطنية للتوزيع والإعلان، الجمهورية العراقية، ؛ 91 ام.

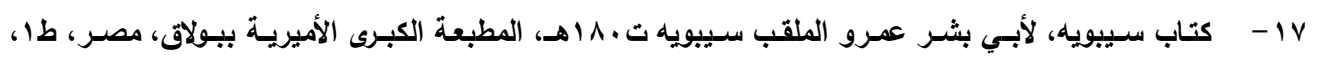

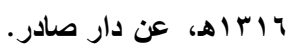


العـــــــــد السـابع والثلاثون

1 ا - كتاب العبين، لأبسي عبد الـرحمن الظليل بـن أحمد الفراهيدي ته Vاهـ، تـح د.مهدي المخزومسي - د.إبـراهيم

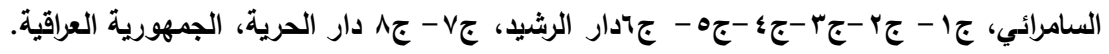

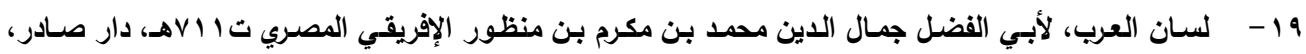

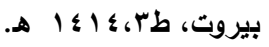

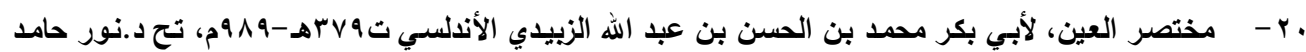

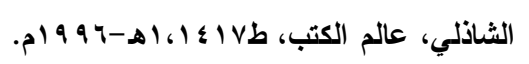

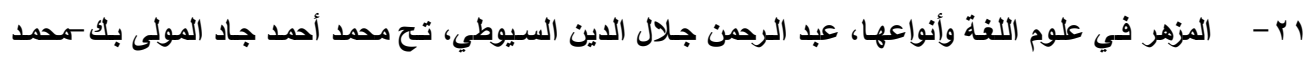
أبو الفضل إبراهيم-علي محمد البجاوي، منشورات المكتبة العصرية، صيداب-بيزوت.

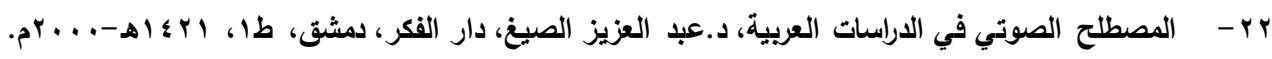

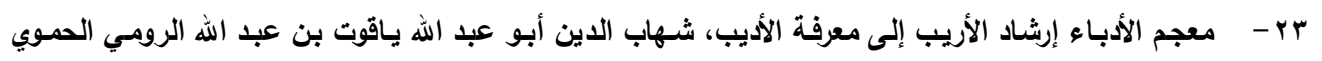

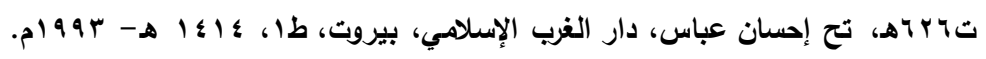

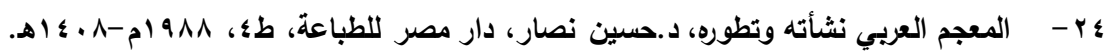
الزسائل الجامعية والبحوث

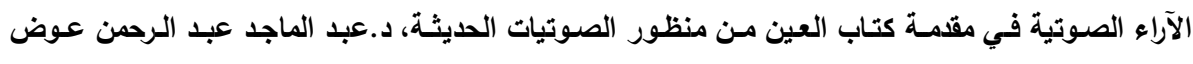

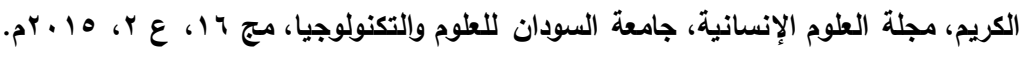

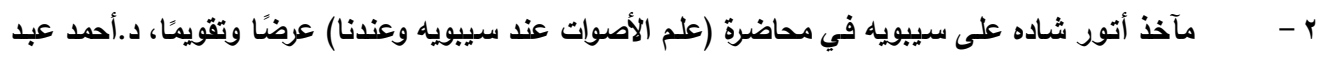

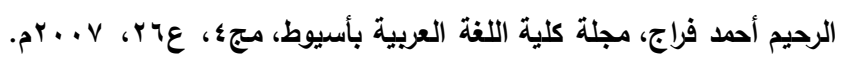

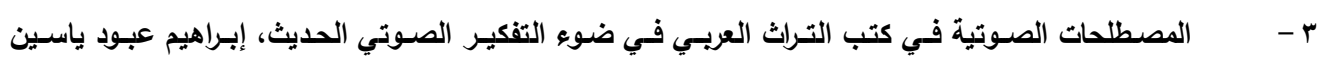

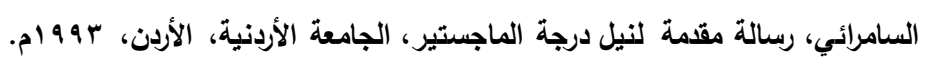

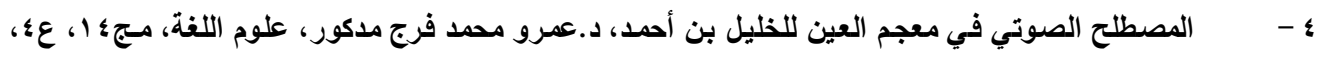

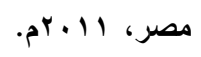

مفهوما الجهر والهمس بين سيبويه وعلمـاء الأصسوات المحدثين، د.عبد العزيز الصيغ، مجلة كلية الآداب، $-0$

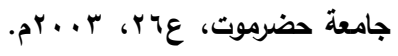

